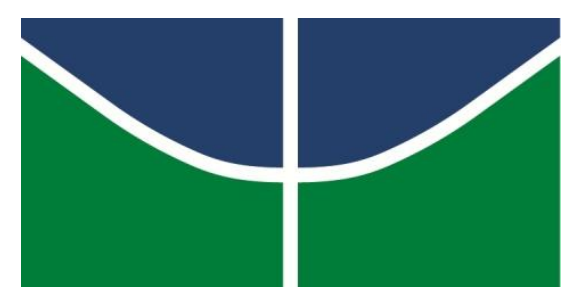

UNIVERSIDADE DE BRASÍLIA - UnB

INSTITUTO DE CIÊNCIAS SOCIAIS - ICS

DEPARTAMENTO DE SOCIOLOGIA - SOL

\title{
A invenção do centro histórico de São Luís/MA: sentidos de um lugar de memória
}

Vinícius Dino Fonseca de Castro e Costa

Brasília/DF

Dezembro de 2017 


\section{VINÍCIUS DINO FONSECA DE CASTRO E COSTA}

\section{A INVENÇÃO DO CENTRO HISTÓRICO DE SÃO LUÍS/MA: SENTIDOS DE UM LUGAR DE MEMÓRIA}

Monografia apresentada ao Departamento de Sociologia da Universidade de Brasília como um dos requisitos para a obtenção do grau de bacharel em Ciências Sociais, com habilitação em Sociologia.

Orientador: Prof. Dr. Edson Silva de Farias (SOL/UnB)

Brasília/DF

Dezembro de 2017 


\section{AGRADECIMENTOS}

Aos meus pais Deane e Flávio, que me deram as condições e o apoio (em todos os sentidos possíveis) para a conclusão deste curso de graduação.

À minha avó Denei, por me acolher em sua casa durante o período da pesquisa de campo.

Ao professor Edson Farias, pela orientação, pelas aulas instigantes e por me proporcionar experiências intelectuais que me ajudam a compreender o significado de "formação".

Aos amigos e companheiros de graduação Artur Guimarães, Artur Lins, Felipe Moretti, Laura Carvalho, Lucas Facó, Mateus Leite e Takeshi Ohashy, pela presença nas diversas fases do curso e pelos incontáveis ensinamentos, seja nos corredores da universidade ou na mesa do bar.

Ao companheiro no amor e na vida Pedro Alvarenga, pelo apoio, escuta e sugestões em vários momentos da construção do trabalho.

Aos colegas do grupo de estudos em sociologia da cultura Beatriz Romão, Bruno Gontyjo, Fernando Franciosi, Flávia Ferreira e Matheus da Costa, pelas discussões, ideias e inquietações compartilhadas.

Aos amigos Susan Lucena e Ítalo Lima, pela companhia e sugestões durante o trabalho de campo.

Às interlocutoras e interlocutores em campo, que gentilmente me cederam parte de seu tempo para conversar e responder a perguntas nem sempre bem formuladas.

Ao grupo de pesquisa Cultura, Memória e Desenvolvimento (CMD), pelos qualificados e inspiradores encontros anuais.

Aos professores e colegas do Programa de Educação Tutorial da Sociologia (PET/SOL).

Às professoras e professores dos departamentos de Sociologia e Antropologia da UnB.

À Universidade de Brasília, por ter sido minha casa nos últimos cinco anos e ter me proporcionado experiências decisivas que me fizeram ser quem sou hoje.

À cidade de São Luís, cuja enorme riqueza humana tentei, nas páginas que se seguem, ao menos tatear. 


\section{RESUMO}

O objetivo geral desta monografia é compreender o processo de invenção do centro histórico da cidade de São Luís, Maranhão, enquanto recorte espacial e paisagem urbana portadora de um valor de excepcionalidade. Busco interpretar a maneira como se deu historicamente esse processo de diferenciação, analisando a construção simbólica dessa excepcionalidade e alguns de seus efeitos e durações no presente. Para tanto, inicio com uma exploração etnográfica de alguns dos sentidos contemporâneos desse lugar de memória. A esse exercício de observação, se soma a perspectiva histórica de longa duração: tomo os sentidos atribuídos a essa paisagem urbana como nexos em uma dinâmica social de longo prazo, marcada por dois momentos decisivos. Nesse tramado sociocultural, procuro observar políticas da imagem que estão por trás da configuração atual do centro histórico de São Luís. O ponto de chegada é uma reflexão sobre o modo como os espaços públicos urbanos podem ser palco de processos civilizadores distintos que, contudo, se interpenetram. 


\section{SUMÁRIO}

INTRODUÇÃO - Patriarcado urbano e lógica de condomínio no crescimento urbano de São Luís

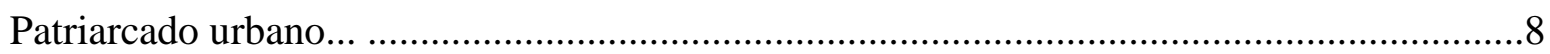



Lógica de condomínio em São Luís e o centro histórico como contraparte..........................15

CAPÍTULO I - Exercício de observação: cartografia de um lugar de memória. .21

CAPÍTULO II - O problema: a invenção do centro histórico de São Luís e seus

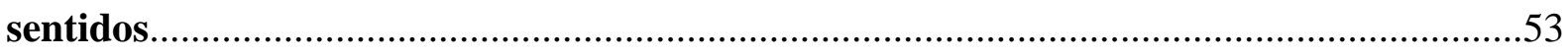



Lugar de memória, processualidade de longa duração e figuração.....................................57

História da cidade como história das guerras de imagens.................................................64

CAPÍTULO III - Momentos decisivos da invenção do centro histórico.........................71

Preâmbulo: decadência e cultura intelectual na São Luís do Segundo Reinado.....................71

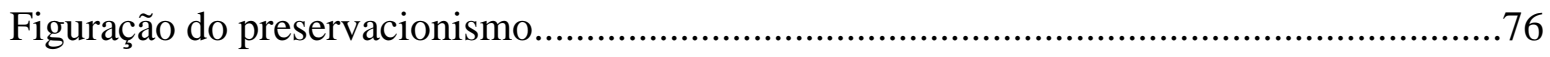

Digressão: patrimônio histórico e artístico como ideia fora do lugar..................................85



CONSIDERAÇÕES FINAIS - Espaços públicos urbanos e processos de civilização..102 


\title{
Introdução
}

\section{Patriarcado urbano e lógica de condomínio no crescimento urbano de}

\author{
São Luís
}

Saí menino de minha terra.

Passei trinta anos longe dela.

De vez em quando me diziam:

Sua terra está completamente mudada,

Tem avenidas, arranha-céus...

É hoje uma bonita cidade!

Meu coração ficava pequenino.

Revi afinal o meu Recife.

Está de fato completamente mudado.

Tem avenidas, arranha-céus.

É hoje uma bonita cidade.

Diabo leve quem pôs bonita a minha terra!

Manuel Bandeira, Minha Terra

Atribui-se ao poeta francês Paul Valéry a frase que diz que "[u]m poema nunca é terminado, e sim abandonado". Mutatis mutandis (a feitura do poema segue lógica diferente daquela do texto acadêmico), e com base na minha incipiente experiência de pesquisa em ciências sociais, creio que de certa forma se poderia afirmar o mesmo sobre os esforços de investigação em uma disciplina como a sociologia. Pois um problema ou questão não se encerra em si mesmo; antes, faz parte de um conjunto de outros problemas e questões que remetem uns aos outros, em uma rede que, se exaustivamente desdobrada, talvez se estendesse em tantas camadas quantas são as que constituem as inúmeras experiências humanas no mundo. (Jorge Luis Borges narrava, em seu pequeno conto Do rigor na ciência, a história de um império cujos cartógrafos, havendo chegado a um extraordinário nível de excelência e perfeccionismo, elaboraram um mapa tão fiel e detalhado, que o tamanho deste acabou coincidindo com o do próprio império, ponto por ponto.) Nesse sentido, uma reflexão nunca é fechada, terminada, e sim está em curso, está sendo, de modo que enseja aberturas para que outros fios sejam puxados e teçam novos problemas, pensamentos e compreensões. Um fluxo como esse só pode ser interrompido se largado de mão. 
É com esse mote que exponho a seguir uma reflexão sobre a configuração urbana do centro histórico de São Luís/MA, dentre muitas outras possíveis. Essa reflexão possui, além de um contexto acadêmico, também um entorno social e político. Sendo assim, é a essa contextualização que as páginas desta introdução se dedicam.

Antes de avançar, porém, é importante resumir brevemente o percurso realizado. $\mathrm{O}$ primeiro capítulo foi construído através de um olhar etnográfico, reunindo um conjunto de observações entretecidas na forma de diário de campo, com o intuito captar alguns dos diversos sentidos atribuídos ao centro histórico de São Luís por parte de seus usuários contemporâneos. Partindo dessas observações, foi possível construir, em seguida, o problema da pesquisa, explicitando seus fundamentos teóricos. Para responder ao problema em torno da invenção do centro histórico de São Luís - seu surgimento enquanto categoria e recorte espacial, seus diversos sentidos -, tomei-a como processo social de longa duração. Recorrendo à sociologia processual e figuracional de Norbert Elias - que interpreta processos sociais abrangentes a partir da análise mais detida de algumas de suas conjunturas específicas (as figurações) -, procedi assim à construção de um modelo desse processo, apreendido por meio de duas figurações principais: o preservacionismo e a reconstrução. No plano dos procedimentos analíticos, portanto, examinei dois momentos decisivos da invenção do centro histórico, correspondendo cada um a uma das figurações mencionadas.

Nesse sentido, a exposição obedece mais ou menos ao seguinte esquema: nesta introdução, busquei compreender como se dá a triangulação entre formação patriarcal, lógica de condomínio e crescimento urbano nas capitais brasileiras e nordestinas contemporâneas, com o intuito de desenhar um quadro geral no qual situar o problema do centro histórico. Em seguida, no capítulo 1, construí um exercício de observação do centro através de um olhar etnográfico e "cartográfico", com recurso à fotografia ${ }^{1}$. Nesse exercício, busquei identificar, nessa paisagem contemporânea, alguns efeitos sincrônicos do processo de invenção que posteriormente é analisado em profundidade diacrônica. No capítulo 2, tentei expor propriamente o problema de pesquisa, explicitando alguns pressupostos teóricos que orientaram sua elaboração. Para tanto, discuto o conceito de lugar de memória, a perspectiva processual de longa duração e a ferramenta analítica que é o conceito de figuração. No capítulo 3, procedi propriamente a analisar as figurações do processo de invenção do centro histórico. Nele, o objeto foram dois "momentos decisivos" dessa invenção, que se desenrola

\footnotetext{
${ }^{1}$ Todas as fotografias do trabalho são de minha autoria, exceto quando for indicada outra fonte.
} 
ao longo do século XX. No capítulo 1 os materiais empíricos são resultantes de "observação participante", enquanto no capítulo 3 utilizei principalmente as chamadas fontes secundárias.

Assim, a monografia possui um escopo duplo: o de fazer um esforço de compreensão de alguns pontos do mapa atual do centro histórico, em sua concretude ${ }^{2}$, e operar uma síntese que permita compreender a longa duração dos fluxos de atribuição de sentido ao centro de São Luís (sem a pretensão de originalidade no levantamento dos dados empíricos; antes, é como uma tentativa de sistematização feita de um ponto de vista sociológico). Penso que assim é possível contribuir também para um estudo comparado de centros e cidades "históricas", a partir do acúmulo de observações etnográficas sobre as especificidades de cada lugar. A seguir, passo à reflexão introdutória que ajuda a situar o problema em torno do centro histórico no quadro mais amplo do crescimento urbano de São Luís.

\section{Patriarcado urbano}

Para esta introdução, a reflexão inicial que busco elaborar consiste em, primeiramente, caracterizar a estrutura da sociedade brasileira como resultado de um patriarcalismo secular, renovado e atualizado geração após geração (patriarcalismo esse inicialmente escravista, que adapta, em um segundo momento, seus hábitos e práticas às relações sociais de produção inauguradas pelo trabalho assalariado). Em segundo lugar, observar como a lógica de condomínio, no Brasil contemporâneo, pode ser interpretada como uma figura dessa atualização intergeracional de padrões de comportamento, contando, evidentemente, com inflexões e transformações. E terceiro, finalmente, relacionar os processos sociais descritos nas etapas anteriores ao crescimento urbano de São Luís, com o intuito de situar nesse quadro geral o problema do centro histórico da cidade e de seus sentidos.

Para tanto, parto do pressuposto de que o modo como se configura o Brasil contemporâneo resulta do curso de formação de uma sociedade nacional oligárquica e excludente do ponto de vista socioeconômico, características longevas que, por sua forma específica, atribuem ao país feições de colônia, tal como apontado pelo autor quilombola Antônio Bispo dos Santos (2015, p. 76):

\footnotetext{
2 "O concreto é concreto porque é a síntese de múltiplas determinações, portanto, unidade da diversidade" (MARX, 2011, p. 54).
} 
Só que hoje, os colonizadores, ao invés de se denominarem Império Ultramarino, denominam a sua organização de Estado Democrático de Direito e não apenas queimam, mas também inundam, implodem, trituram, soterram, reviram com suas máquinas de terraplanagem tudo aquilo que é fundamental para a existência das nossas comunidades, ou seja, os nossos territórios e todos os símbolos e significações dos nossos modos de vida.

Se é verdade que no Brasil a vida moderna se desenvolve a partir de um conjunto de padrões socioculturais herdados do período colonial, como sugere Sérgio Buarque de Holanda ${ }^{3}$, torna-se então essencial compreender ao menos alguns desses padrões.

Em Sobrados e Mucambos, Gilberto Freyre (2002) descreve o lento processo de decadência do patriarcado rural brasileiro, principalmente a partir do século XIX, ao mesmo tempo em que identifica algumas tendências de desenvolvimento urbano por que passou o Brasil nesse mesmo século. Antes, em Casa-Grande e Senzala, o autor já havia definido a América Portuguesa como uma sociedade híbrida, escravocrata e patriarcal, só podendo o modelo econômico agroexportador ser compreendido em íntima relação com a reprodução social e cultural da família, enquanto instituição centralizadora. Assim, com o desenvolvimento das cidades brasileiras, esta não perde sua centralidade: em vez disso, o que ocorre é uma complexificação ${ }^{4}$ do modo de dominação familiar-patriarcal e a multiplicação de classes sociais intermediárias, sem romper com a escravidão. Segundo Freyre (2002, p. 750), a partir dos séculos XVIII e XIX o patriarcalismo brasileiro vem dos engenhos para os sobrados, isto é, se transfere para as cidades (adaptando-se). Aqui, interessa-me propor mais um elo nesse encadeamento: ele se transfere também para os condomínios.

Mas, em linhas gerais, em que consiste esse "patriarcado escravocrático", formado pela unidade básica da "família tutelar”? (FREYRE, 2002, p. 668-669) Dito com um

\footnotetext{
${ }^{3}$ Holanda (1995, p. 79) chama atenção para o papel da "herança rural" que seria responsável por uma "radical incompatibilidade entre as formas de vida copiadas de nações socialmente mais avançadas, de um lado, e o patriarcalismo e personalismo fixados entre nós por uma tradição de origens seculares". Pode-se considerar que "mais avançadas", na perspectiva do autor, seriam justamente as nações modernas cujas burguesias lograram conduzir uma industrialização marcada pelo "espírito do capitalismo" (WEBER, 2004), ao mesmo tempo em que consolidavam Estados nacionais burocráticos baseados na dominação racional-legal. Outras perspectivas teóricas, no entanto, enfatizam as ligações intrínsecas entre colonização e modernidade, considerando os dois elementos como faces de um mesmo processo, tal como posto, por exemplo, por Aníbal Quijano (1992, p. 17): "la racionalidad/modernidad europeo-occidental se constituye no solamente en conflictivo diálogo con la Iglesia y con la religión, sino también en el mismo proceso de reestructuración del poder, de una parte, en relaciones sociales urbanas y capitalistas y estados-nación; y al mismo tiempo, de colonización del resto del mundo".

${ }^{4}$ Segundo Jessé Souza (2000, p. 234-235), "[t]oda a questão do familismo se complexifica enormemente em Sobrados e Mucambos, ou seja, na passagem do patriarcalismo rural para o urbano. A decadência do patriarcado rural brasileiro está ligada diretamente à ascendência da cultura citadina no Brasil”.
} 
vocabulário que não é o de Freyre, trata-se de um conjunto de relações sociais que privilegia os homens brancos proprietários, em detrimento de todos os demais grupos sociais, escravizados, racializados e/ou generificados de maneira subalterna. No contexto das cidades brasileiras, o autor o descreve fazendo referências a diversas facetas dessa formação social: a relação entre homens e mulheres, maridos e esposas, pais e filhos, senhores e escravos, brasileiros e europeus. O lugar privilegiado de observação dessas relações é justamente a casa:

[o] centro de interesse para o nosso estudo de choque entre raças, entre culturas, entre idades, entre cores, entre os dois sexos, não é nenhum campo sensacional de batalha [...]. O centro de interesse para o nosso estudo desses antagonismos e das acomodações que lhes atenuaram as durezas, continua a ser a casa - a casa maior em relação com a menor, as duas em relação com a rua, com a praça, com a terra, com o solo, com o mato, com o próprio mar. (FREYRE, 2002, p. 659)

Nesse sentido, o autor descreve como, no século XIX, apesar de um ganho de importância da rua no interior de uma balança de poder que sempre pendeu para o lado da casa, esta última continua sendo decisiva na definição dos padrões de comportamento ${ }^{5}$ :

Mas mesmo desprestigiada pela rua e diminuída nas funções patriarcais (que manteve até no centro de algumas cidades); diminuída pela matriz, pela catedral, pela fábrica, pelo colégio, pelo hotel, pelo laboratório, pela botica a casa do século XIX continuou a influir, como nenhuma dessas forças, sobre a formação social do brasileiro de cidade. O sobrado, mais europeu, formando um tipo, o mucambo, mais africano ou indígena, formando outro tipo social de homem. (FREYRE, 2002 p. 663)

Com referência a um contexto empírico bastante diverso, Norbert Elias demonstra, em A Sociedade de Corte, o modo como estruturas de habitação podem ser tomadas como indicadores de estruturas sociais. Para Elias (2001, p. 67), “a todo modo de agrupamentos humano corresponde uma determinada configuração do espaço onde aqueles indivíduos de fato estão ou podem estar reunidos”. Nesse sentido, ele observa, por exemplo, como a corte

\footnotetext{
5 “[P]lanos e ações, impulsos emocionais e racionais de pessoas isoladas constantemente se entrelaçam de modo amistoso ou hostil. Esse tecido básico, resultante de muitos planos e ações isolados, pode dar origem a mudanças e modelos que nenhuma pessoa isolada planejou ou criou. Dessa interdependência de pessoas surge uma ordem sui generis, uma ordem mais irresistível e mais forte do que a vontade e a razão das pessoas isoladas que a compõem" (ELIAS, 1993, p. 194).
} 
francesa do Antigo Regime se constitui como uma extensão da casa do próprio rei, de modo que, para compreender o grande "domicílio real" que ela significa, o autor se volta aos primórdios dessa estrutura habitacional, os quais ele encontra na dominação patriarcal de um "senhor da casa".

Pensando assim as relações entre estrutura de habitação e estrutura social, seria possível sugerir que, no caso das classes médias e altas brasileiras, a forma da relação entre casa e rua também é indicativa de uma determinada estrutura social e seus padrões de comportamento correspondentes. Sobre essa relação, Jessé Souza, lendo Freyre, aponta que

[o] sobrado, a casa do senhor rural na cidade, é uma espécie de prolongamento material da personalidade do senhor. Sua relação com a rua, essa espécie arquetípica e primitiva de espaço público, é de desprezo, a rua é o lixo da casa, representa o perigo, o escuro, era simplesmente a não-casa, uma ausência. (SOUZA, 2000, p. 237)

De forma semelhante, Roberto DaMatta (1997, p. 57) afirma que

[e]m todo caso, se a casa distingue esse espaço de calma, repouso, recuperação e hospitalidade, enfim, de tudo aquilo que define a nossa ideia de 'amor', 'carinho' e 'calor humano', a rua é um espaço definido precisamente ao inverso. Terra que pertence ao 'governo' ou ao 'povo' e que está sempre repleta de fluidez e movimento. A rua é um local perigoso. Aliás sempre foi assim, e as descrições deste espaço como zona livre são copiosas. [...] [C]omo Ferdinand Denis que, em 1880, também viu a grande sociedade ou elite do Rio morando em chácaras afastadas e deixando a 'cidade' com suas ruas entregues a capoeiras, vagabundos e gente de todo tipo.

É esse aspecto específico da formação patriarcal que aqui interessa reter: do ponto de vista do sobrado ${ }^{6}$ descrito por Freyre, dominado pela autoridade do homem branco proprietário, a rua é elemento estranho e disruptivo.

\footnotetext{
${ }^{6}$ Sobre um dos elementos mais típicos da arquitetura dos sobrados de São Luís, a historiadora Maria de Lourdes Lauande Lacroix (2012, p. 83) faz uma comparação sugestiva: “O mirante, integrado à fachada do sobrado, infunde certa imponência, lembrando as torres ou torreões dos castelos antigos".
} 


\section{Lógica de condomínio}

"Se queremos que tudo continue como está, é preciso que tudo mude."

Tomasi di Lampedusa, O Leopardo

No entanto, no que essa caracterização, feita por Freyre, do Brasil enquanto paisagem patriarcal ajuda a abordar o objeto de reflexão desta introdução, a saber, as dinâmicas socioespaciais das cidades brasileiras contemporâneas, em geral, e o crescimento urbano da cidade de São Luís, em particular? A meu ver, o nexo se encontra no fato de que, como apontado mais acima, o patriarcalismo brasileiro migra dos sobrados para os condomínios, e a lógica destes passa a orientar cada vez mais o modo de organização das cidades e da vida em comum. Essa proposição pode ser ilustrada com uma referência a dois celebrados filmes de longa-metragem de ficção realizados nos últimos anos pelo diretor Kleber Mendonça Filho: $O$ Som ao Redor (2013) e Aquarius (2016). Pois creio que neles é possível identificar, traduzidos em forma cinematográfica, alguns traços que unem patriarcalismo e lógica de condomínio na atual experiência urbana das capitais brasileira.

A antropóloga Teresa Caldeira, em seu livro Cidade de Muros, faz uma análise "da forma pela qual o crime, o medo da violência e o desrespeito aos direitos da cidadania têm se combinado a transformações urbanas para produzir um novo padrão de segregação espacial nas duas últimas décadas". Assim, a autora descreve, a partir do caso da cidade de São Paulo, um processo de privatização da segurança (associado ao afeto do medo) que se traduz na forma da edificação do que ela chama de "enclaves fortificados", uma categoria geral que engloba não somente os condomínios residenciais, mas também outras formas de "universos privados", como conjuntos de escritórios e shopping centers. Segundo Caldeira (2000, p. 258259),

Todos os tipos de enclaves fortificados partilham algumas características básicas. São propriedade privada para uso coletivo e enfatizam o valor do que é privado e restrito ao mesmo tempo que desvalorizam o que é público e aberto na cidade. São fisicamente demarcados e isolados por muros, grades, espaços vazios e detalhes arquitetônicos. São voltados para o interior e não em direção à rua, cuja vida pública rejeitam explicitamente. São controlados por guardas armados e sistemas de segurança, que impõem as regras de inclusão e exclusão. 
A análise de Caldeira ecoa, de certa forma, na teorização do psicanalista Christian Dunker, que em seu livro Mal-Estar, Sofrimento e Sintoma propõe uma "psicopatologia do Brasil entre muros" ${ }^{7}$. Na tentativa de compreender a implantação da psicanálise no Brasil, e, mais especificamente, a disseminação do pensamento lacaniano, a partir dos anos 70, Dunker sugere que essa implantação está na contrapartida de formas específicas de mal-estar, sofrimento e sintoma. Essas formas de mal-estar, por sua vez, se inserem no interior do que o autor chama de "um modo de vida ascendente desde então" (isto é, os anos 70): a "vida em forma de condomínio" (DUNKER, 2015, p. 42). No sentido dessa última noção, ele passa a descrever essa forma de vida, encontrando o que chama de uma "topologia da segregação". Segundo o autor,

[a]o entrar em um desses modernos condomínios, projetados com a mais tenra engenharia urbanística, temos o sentimento pacificador de que enfim encontramos alguma ordem e segurança. Rapidamente nos damos conta de que ali há uma forma de vida na qual a precariedade, o risco e a indeterminação teriam sido abolidos. O espaço é homogêneo, conforme certas regras de estilo. Dentro dele, os lugares são bem distribuídos, as posições estão confortavelmente ocupadas. A polícia parece realmente presente, apesar de particular. Tudo o mais é funcional, administrado e limpo. [...] De acordo com essa lógica, é preciso exportar problemas e, ao mesmo tempo, restringir seu retorno pelo reforço de barreiras fiscais, controle de fronteiras e restrição de circulação de pessoas. (DUNKER, 2015, p. $47 ; 68)$

Assim, essa topologia atualiza, nas cidades brasileiras contemporâneas, o apartheid instaurado pela formação patriarcal-escravista. Feita essa caracterização, se torna possível abordar brevemente o modo como esses aspectos aparecem nos filmes mencionados acima.

Em O Som ao Redor (2012), o espectador é apresentado aos moradores de uma rua de um bairro nobre da cidade do Recife, a poucos metros da praia. Porém, antes de começar a percorrer esse cenário, através de um plano-sequência feito no piso térreo de um condomínio vertical, por entre os muitos carros estacionados na garagem, o filme traz um prólogo composto por imagens estáticas. São fotografias em preto e branco de uma paisagem pernambucana rural: a cerca de uma fazenda, uma família de camponeses, trabalhadores

\footnotetext{
${ }^{7}$ Dunker (2015, p. 35) pensa seu livro como uma contribuição ao conceito de "patologias do social", que apesar de extrapolar os limites de uma perspectiva como a sociológica, pode ser útil para o campo da crítica social, entendida de forma ampla.
} 
levantando foices, um canavial com uma colina ao fundo, uma casa-grande em estilo português, com terraço, uma fila de lavradores com enxadas. O personagem principal, João, é corretor de imóveis, e trabalha vendendo apartamentos que são propriedade de seu avô. Nesse sentido, seu trabalho é tão somente reproduzir e multiplicar o patrimônio da família. No centro da trama do filme ${ }^{8}$, está a chegada de dois homens para oferecer um serviço de segurança particular, que visitam Francisco, o avô de João, para obter seu aval para que passem a trabalhar na rua. Após fazê-los aguardar em pé, próximos à porta dos fundos do apartamento, o patriarca os recebe brevemente, tem com eles uma conversa tensa e finalmente dá sua autorização.

Além dos imóveis na cidade, o patriarca também possui um engenho no interior do estado, ao qual João leva sua companheira Sofia para passear. O casal percorre o engenho, em uma sequência que explora ruínas alegóricas ${ }^{9}$ : a casa-grande, a fachada de um cinema antigo, as máquinas desativadas.

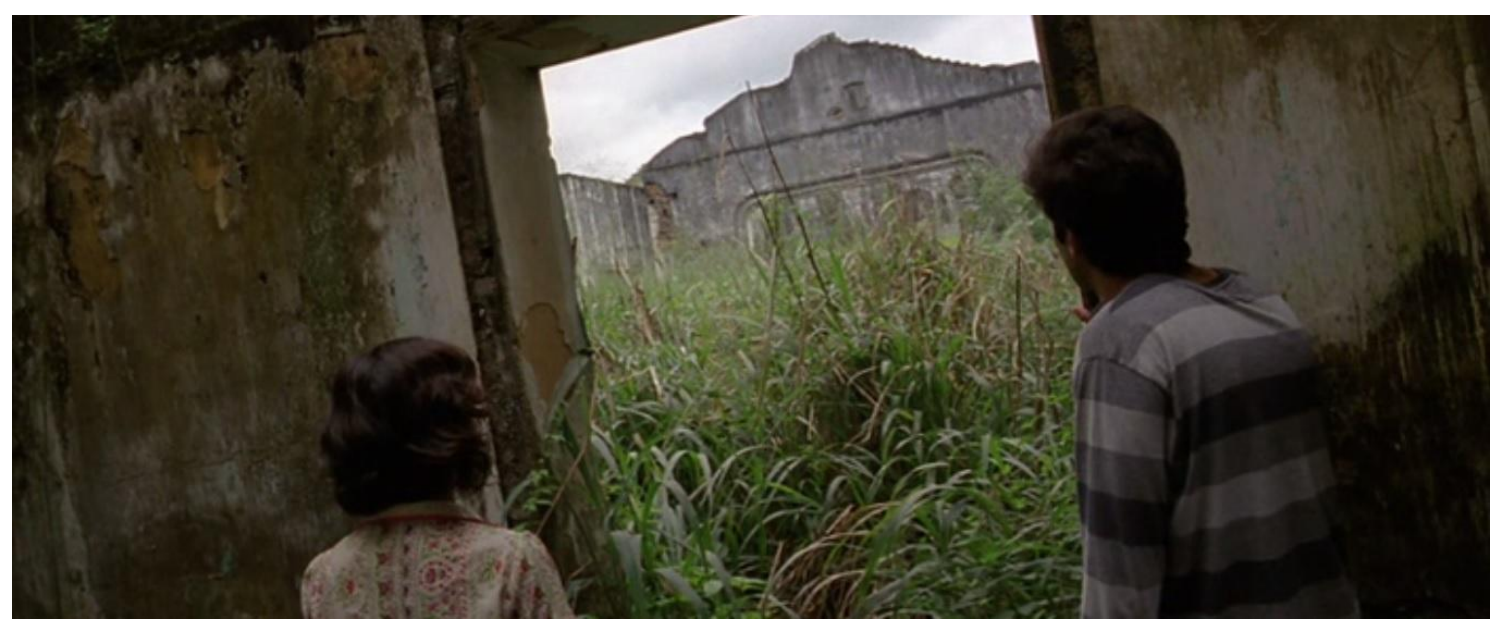

Frame de O Som ao Redor: alegorias da colonização

Nessas linhas gerais o filme constrói sua apresentação dessa rua do Recife contemporâneo, tomada por condomínios fortificados (cujos imóveis pertencem em boa parte a uma mesma família) e apavorada com as ameaças da violência urbana. Esses ingredientes de tensão, acumulados ao longo do filme, culminam com uma grande explosão final. Penso que não seria totalmente fora de propósito dizer que essa explosão, do filme gravado em 2012,

\footnotetext{
${ }^{8}$ Sua sinopse é a seguinte: “A presença de um grupo de seguranças em uma rua de classe média na zona sul do Recife muda a vida dos moradores do local. Ao mesmo tempo em que alguns comemoram a tranquilidade trazida, outros passam por momentos de extrema tensão".

9 "Como ruína, a história se fundiu sensorialmente com o cenário. Sob essa forma, a história não constitui um processo de vida eterna, mas de inevitável declínio. Com isso, a alegoria reconhece estar além do belo. As alegorias são no reino dos pensamentos o que são as ruínas no reino das coisas" (BENJAMIN, 1984, p. 200).
} 
antecipa aquelas de junho de 2013; com efeito, a questão urbana foi o estopim da revolta que por pouco mais de uma semana tomou as ruas das principais capitais brasileiras ${ }^{10}$. Pois, como afirmou Walter Benjamin (1993, p. 190), “[u]ma das tarefas mais importantes da arte foi sempre a de gerar uma demanda cujo atendimento integral só poderia produzir-se mais tarde".

Em Aquarius (2016), há novamente um empreendimento familiar-patriarcal que incide diretamente na organização do espaço e da paisagem urbana. A Bonfim Engenharia, a empresa que pressiona a personagem principal Clara, para forçar a venda de seu apartamento, é representada por avô e neto que a intimidam. O que se complexifica em relação a $O$ Som ao Redor, a meu ver, é a problemática da "memória-fixada-ao-lugar", que será central também no momento de abordar o caso do centro histórico de São Luís. Uma sinopse possível do filme é a seguinte:

Clara (Sonia Braga) tem 65 anos, é jornalista aposentada, viúva e mãe de três adultos. Ela mora em um apartamento localizado na Av. Boa Viagem, no Recife, onde criou seus filhos e viveu boa parte de sua vida. Interessada em construir um novo prédio no espaço, os responsáveis por uma construtora conseguiram adquirir quase todos os apartamentos do prédio, menos o dela. Por mais que tenha deixado bem claro que não pretende vendê-lo, Clara sofre todo tipo de assédio e ameaça para que mude de ideia. ${ }^{11}$

Essas breves descrições, e principalmente as obras cinematográficas a que dizem respeito, ilustram a conexão entre formação patriarcal e lógica de condomínio que aqui interessa explicitar. É precisamente esta última articulação, com todas suas consequências excludentes, que penso que opera também na produção do espaço urbano da São Luís contemporânea, questão que abordo a seguir.

\section{Lógica de condomínio em São Luís e o centro histórico como contraparte}

O que os filmes fazem, em síntese, é dar um rosto aos movimentos da economia política, e penso que, se feitas as devidas mediações, as imagens que oferecem podem extrapolar a experiência recifense e ser tomadas como representativas também do crescimento urbano de São Luís (e de outras capitais), com suas dinâmicas socioespaciais marcadas por

\footnotetext{
${ }^{10}$ Cf, por exemplo, o texto de Ermínia Maricato É a questão urbana, estúpido!. In: MARICATO [et al.], 2013.

${ }^{11}$ Disponível em http://www.adorocinema.com/filmes/filme-239210/ . (Acesso em 15/11/2017.)
} 
um pano de fundo patriarcal atualizado na forma de vida de condomínio. O economista José Reinaldo Ribeiro Júnior (1999, p. 91) identifica em São Luís, a partir dos anos $70^{12}$, o que ele chama de um "fenômeno re-espacializante":

Destarte, é entre o final dos anos 60 e por todo o desabrochar da década setentista que a capital [...] adquire novo traçado urbano. Suas fronteiras expandem-se, rompendo o bloqueio do corredor limitado pelos rios Bacanga e Anil. São marcos desse fenômeno re-espacializante a construção da ponte José Sarney [sobre o rio Anil], inaugurada em 1970, que encurtaria o caminho da cidade para as praias, enobrecendo uma vasta área do seu território, e a edificação da barragem sobre o rio Bacanga, também concluída no ano de 1970. Abririam-se, assim, duas frentes ocupacionais: uma, ao Norte, em direção ao litoral balneário, futura área nobre da cidade [..], onde os negócios imobiliários ganham vultuosidade, setor da economia urbana que adquire notável dimensão então; outra, a Sudoeste, região de fraca densidade demográfica, mas que logo se tornaria tradicional zona de ocupação periférica da cidade.



Centro histórico de São Luís em primeiro plano, com a ponte do São Francisco, sobre o Rio Anil, e condomínios verticais da Ponta d'Areia ao fundo. Fonte: 9D Studio. ${ }^{13}$

12 “[...] São Luís passou por transformações radicais quanto ao aspecto demográfico-urbanístico. Podemos inclusive demarcar como ponto de partida o final dos anos 60. Aqui, o setor público tem papel fundamental. Obras de infra-estrutura urbana trataram de fazer ressurgir um cenário econômico mais otimista. Desponta a indústria de construção civil como base da mudança” (RIBEIRO JÚNIOR, 1999, p. 106). 
O aspecto central dessa observação do autor, para o argumento aqui perseguido, é a correlação entre expansão territorial e o padrão de segregação socioespacial observado acima. Pois as bases da São Luís moderna, de seu crescimento urbano (a cidade chega à virada do milênio perto de seu primeiro milhão de habitantes), estão nessa "re-espacialização". Como vimos, é também nos anos 70 que a forma de vida em condomínio, teorizada por Caldeira e Dunker, adquire uma ascendência relevante. Principalmente na esteira da expansão na primeira direção indicada por Ribeiro Júnior, vieram a crescer condomínios verticais que dominaram a paisagem das praias ludovicenses, pelo menos das mais próximas ao centro, e do entorno da Lagoa da Jansen. Com efeito, o próprio autor remete esse processo de crescimento aos contrastes descritos por Freyre para o século XIX:

Na recente zona nobre, houve também edificação de conjuntos residenciais (Basa, Renascença, e Conj. São Francisco, por exemplo), estes logicamente em atendimento à procura do segmento social de renda média, exclusivamente. Cinde-se, como de praxe, o habitat para os ricos e o habitat para os pobres, no complexo urbano, revelando-se a estratificação contida na análise de Freyre, aquele dos Sobrados e Mucambos, em equivalência ao existente no rural, onde vigavam Casas Grandes e Senzalas, unidades pertencentes ao sistema organizacional da civilização tropical brasileira, contrastante socialmente. (RIBEIRO JÚNIOR, 1999, p. 94)

Dessa forma, o crescimento urbano que se intensifica nos anos 70, com obras públicas como a ponte do São Francisco (José Sarney) e a barragem do Bacanga, que permitem a reconfiguração re-espacializante da cidade, e também com a chegada de projetos que prometiam uma modernização da economia local, como a planta industrial da ALUMAR (consórcio de fabricantes de alumínio formado pelas multinacionais Alcoa, BHP Billiton e RioTintoAlcan), a construção da Estrada de Ferro Carajás (visando o transporte do minério de ferro paraense para o escoamento, via porto em São Luís) e o próprio Porto do Itaqui (obra planejada já no início do século XX e concluída em 1974), se dá de modo a atualizar um padrão histórico de estratificação, relacionado à formação escravocrata e patriarcal.

Esse processo de crescimento urbano e expansão territorial possui implicações importantes para a configuração do centro antigo da cidade, tema desta pesquisa. Sobretudo, trata-se de uma aceleração do abandono das áreas centrais por parte das classes altas que antes as ocupavam. É nesse sentido que Carlos Reis (2011, p. 138) identifica um

\footnotetext{
${ }^{13}$ Disponível em https://9d.com.br/time-lapse-sao-luis-400-anos-n1/ . Acesso em 17/11/2017.
} 
processo de decadência, iniciado no primeiro quartel do século $\mathrm{XX}$, quando essa área entra em colapso socioeconômico e seus abastados moradores começam a se transferir para novos setores da cidade, considerados mais nobres e salubres.

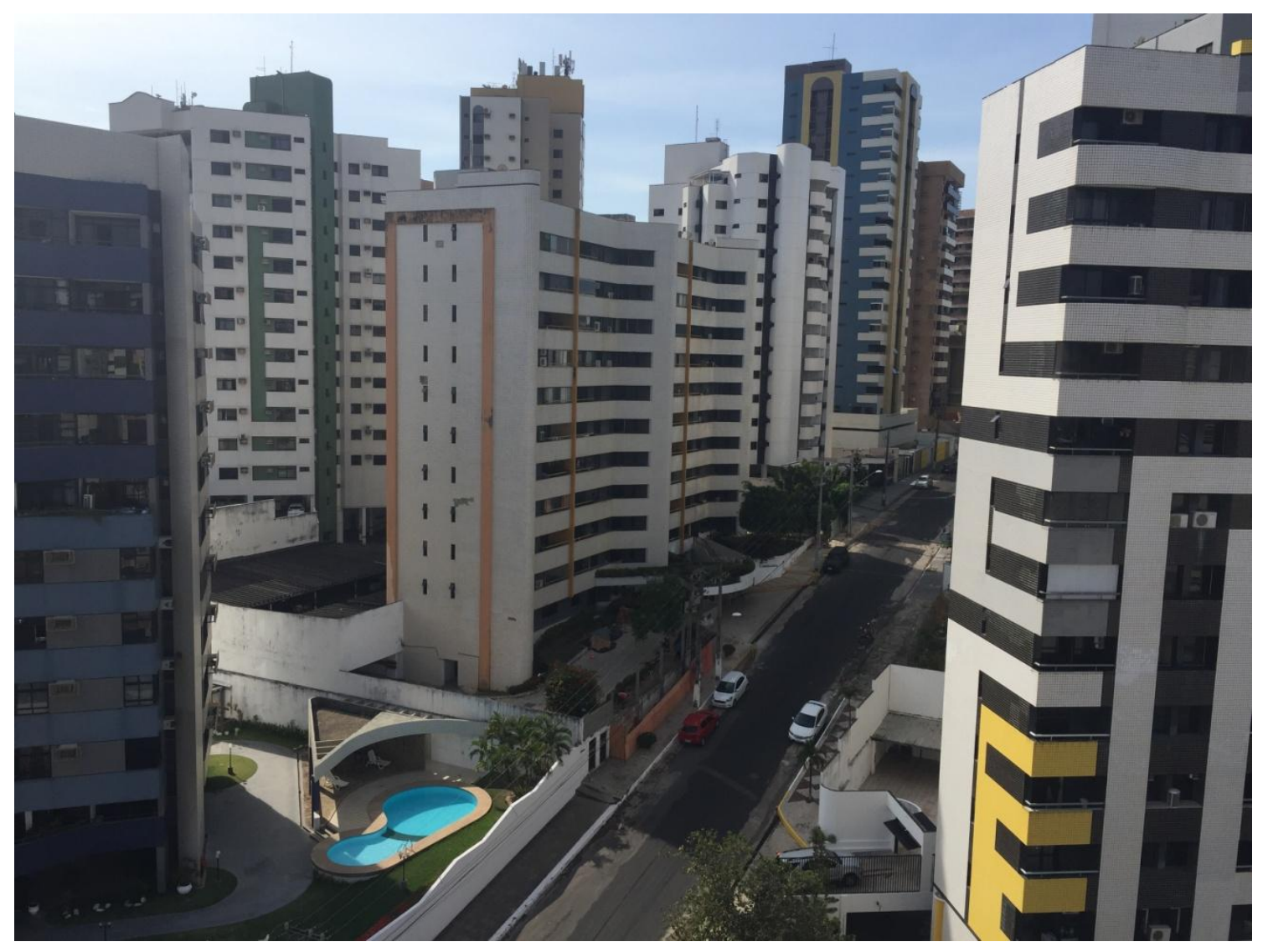

Jardim Renascença 

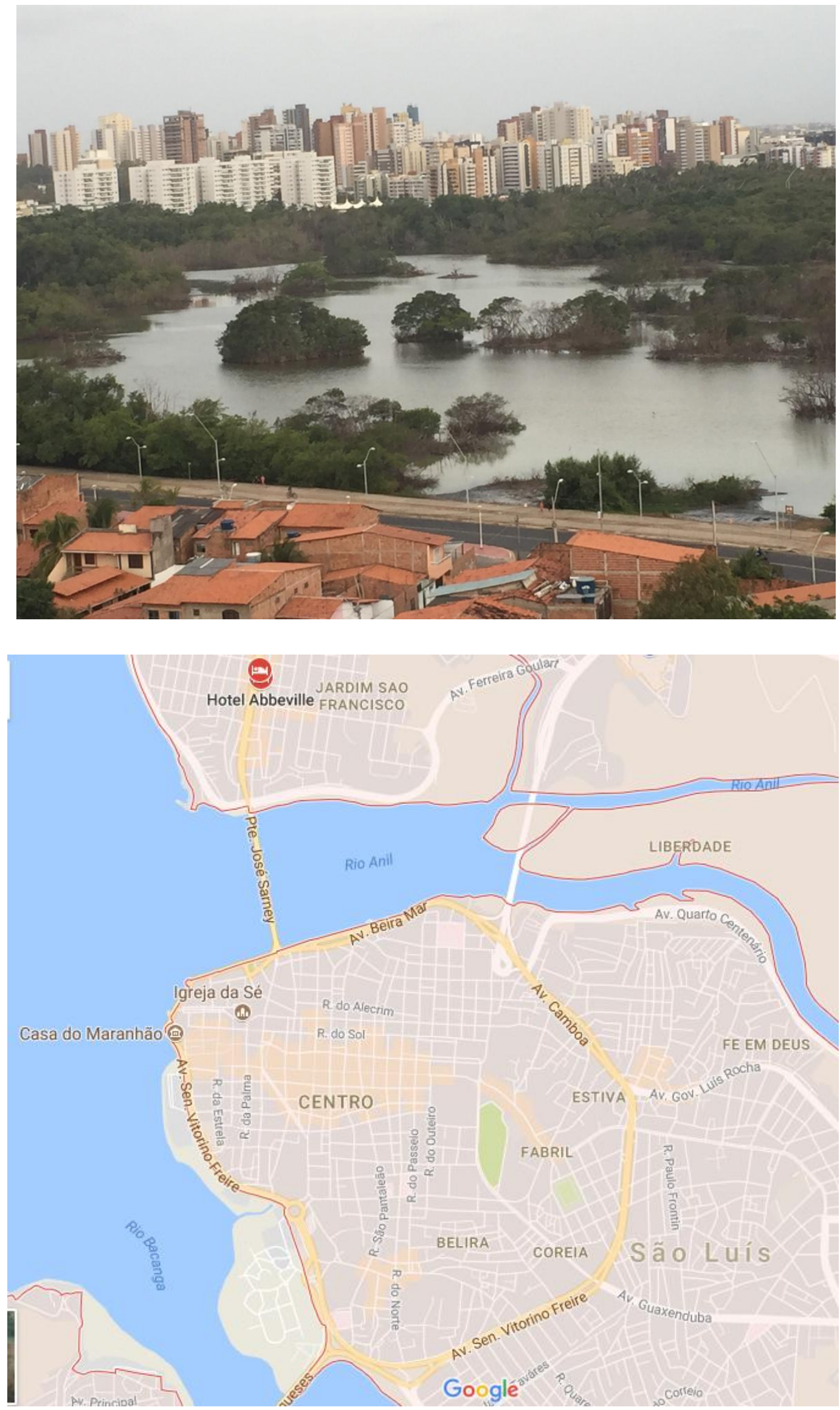

Mapa do centro de São Luís, entre os rios Anil e Bacanga. Fonte: Google 
No entanto, nessa época os "novos setores" ainda estão localizados no entorno do núcleo antigo da cidade, isto é, entre os rios Anil e Bacanga. Segundo José Antonio Viana Lopes, esse núcleo definido pelo urbanismo colonial "chegará ao início do século XX quando, no período republicano, se intensifica o processo de desintegração do traçado urbano tradicional, em quadrículas, e a expansão da cidade para os subúrbios" (LOPES, 2004, p. 27). Após a construção da chamada ponte do São Francisco, e o encurtamento do caminho em direção às praias, essa expansão adquire proporções ainda maiores, ao mesmo tempo em que a lógica de condomínio passa a orientar a produção do espaço urbano, com a valorização desigual de diferentes partes da cidade. Para Geórgia Silva,

[a] valorização da cidade nova remeteu ao abandono gradativo do centro tradicional. A deterioração de seus equipamentos urbanos, o abandono do acervo arquitetônico do bairro da Praia Grande, o decréscimo populacional são mostras desse processo. Decerto, esse esvaziamento econômico levou ao abandono de um grande número de imóveis e à consequente ruína de muitos deles. (SILVA, 2010, p. 79)

Dessa forma, tanto a expansão territorial marcada pela lógica de condomínio quanto a marginalização da região central ${ }^{14}$ se configuram como duas facetas de uma mesma dinâmica de modernização. É essa dinâmica socioespacial que dá as condições para a invenção moderna do centro histórico, tal como descreverei a seguir. E é também com e contra ela que essa invenção adquire seus sentidos públicos, complexos e muitas vezes contraditórios entre si. Considero, no entanto, que é justamente esse feixe de heterogeneidades o que permite tomar o centro histórico como uma contraparte negativa da lógica de condomínio. Pois, se este último aparece como um enclave fortificado e privado, alheio às misturas e às disputas de sentido, o primeiro, graças a seus sentidos múltiplos e às diferenças que nele se cruzam, se constitui como espaço público ${ }^{15}$.

\footnotetext{
14 "Outro aspecto que marca profundamente o padrão citadino brasileiro a partir do início do século XX é o abandono das áreas centrais. Áreas edificadas por meio do excedente de capital das elites coloniais brasileiras foram inteiramente abandonadas por estas mesmas classes. Passaram de áreas valorizadas economicamente a lugares marginais e perigosos, alvo dos recentes investimentos em revitalização urbana" (CHAVES; SILVA, 2015, p. 3-4).

${ }^{15}$ Deixo esse argumento para ser melhor desenvolvido nas considerações finais.
} 


\title{
Capítulo I
}

\section{Exercício de observação: cartografia de um lugar de memória}

\begin{abstract}
Mas a cidade não conta seu passado, ela o contém como as linhas da mão, escrito nos ângulos das ruas, nas grades das janelas, nos corrimãos das escadas, nas antenas dos pára-raios, nos mastros das bandeiras, cada segmento riscado por arranhões, serradelas, entalhes, esfoladuras.
\end{abstract}

Italo Calvino, As cidades invisíveis

As notas etnográficas abaixo, escritas em forma de diário de campo, consistem em um exercício de observação direcionado a captar alguns dos diversos sentidos ${ }^{16}$ atribuídos ao centro histórico de São Luís por parte de seus usuários contemporâneos. Além das minhas observações pessoais, busquei transcrever trechos de falas que escutei nesse campo, inspirado na afirmação de James Clifford (2002, p. 54) de que "[u]ma maneira cada vez mais comum de realizar a produção colaborativa do conhecimento etnográfico é citar os informantes extensa e regularmente" ${ }^{, 17}$.

Nem sempre essas falas foram selecionadas de modo a estabelecer um diálogo direto com os dois momentos decisivos analisados principalmente no capítulo 3. Por vezes, a intenção foi tão somente a de observar pontos específicos do mapa sócio-simbólico do centro histórico, de maneira a permitir a emergência de heterogeneidades. (Desse modo, penso que é possível fornecer elementos para sugerir uma comparação entre as figurações que serão descritas nos capítulo seguintes e a multiplicidade de sentidos circulantes na contemporaneidade desse espaço.)

\footnotetext{
16 “'Sentido' é o sentido subjetivamente visado: a) na realidade $\alpha$, num caso historicamente dado, por um agente, ou $\beta$, em média e aproximadamente, numa quantidade dada de casos, pelos agentes, ou b) num tipo "puro" conceitualmente, construído pelo agente ou pelos agentes concebidos como típicos. Não se trata, de modo algum, de um sentido objetivamente 'correto' ou de um sentido 'verdadeiro' obtido por indagação metafísica. Nisso reside a diferença entre as ciências empíricas da ação, a Sociologia e a História, e todas as ciências dogmáticas, a Jurisprudência, a Lógica, a Ética e a Estética, que pretendem investigar em seus objetos o sentido 'correto' e "válido"” (WEBER, 2012, p. 4).

${ }^{17}$ Procedimento esse que, por sua vez, não é isento de contradições: "Mas esta tática apenas começa a romper a autoridade monofônica. As citações são sempre colocadas pelo citador, e tendem a servir meramente como exemplos ou testemunhos confirmadores. Indo-se além da citação, pode-se imaginar uma polifonia mais radical que 'representaria os nativos e o etnógrafo com vozes diferentes'; mas isso também apenas deslocaria a autoridade etnográfica, confirmando uma vez mais a orquestração final virtuosística feita por um só autor de todos os discursos presentes no texto" (CLIFFORD, 2002, p. 54).
} 
Em outras situações, no entanto, busquei identificar mais explicitamente durações e efeitos do processo de invenção que abordarei nos capítulos posteriores. Além dessas durações efetivas, tentei expor materiais que expressam os tensionamentos e limites de tal processo. Pois a certificação desses limites também enseja uma compreensão fundamental: a de que o significante centro histórico, tal como inventado e imaginado ao longo do processo que destrincharei, de maneira nenhuma esgota a experiência social concreta que se desenrola no espaço significado.

Georges Didi-Huberman, ao comentar o conceito de "sobrevivência" tal como elaborado por Edward B. Tylor e retomado por Aby Warburg, conclui o seguinte:

Diante de tudo isso, Tylor teria descoberto a extrema variedade e a
vertiginosa complexidade dos fatos culturais (o que também se sente ao
percorrer Frazer), mas teria igualmente descoberto algo ainda mais
perturbador (que nunca sentimos ao ler Frazer): a ação vertiginosa do tempo
na atualidade, na 'superfície' presente de uma dada cultura. Essa vertigem se
expressa, inicialmente, na intensa sensação - evidente em si, porém menos
óbvia em suas consequências metodológicas - de que o presente se tece de
múltiplos passados. Daí porque, aos olhos de Tylor, o etnólogo deve se fazer
historiador de cada uma de suas observações. (DIDI-HUBERMAN, 2013, p.
46)

No decorrer da monografia, só poderei abordar a profundidade histórica de alguns dos sentidos que agora, no capítulo 1, aparecem como superfícies. No entanto, é necessário pontuar que cada um dos seguintes usos, sentidos e imagens possui também sua própria história. Dessa forma, os passados que se entrecruzam no presente desse lugar de memória são vários, sendo o que chamei de invenção do centro histórico apenas um deles.

\section{Praia Grande}

Novembro de 2017

A redefinição da identidade do bairro da Praia Grande, operada pelo Projeto Reviver, deixou suas marcas no imaginário coletivo, de modo que é extremamente comum que os frequentadores assim se refiram ao espaço (em geral, apenas como "Reviver"). Essas marcas 
se fazem notar no nome de diversos estabelecimentos comerciais da região e, por consequência, na paisagem do lugar.

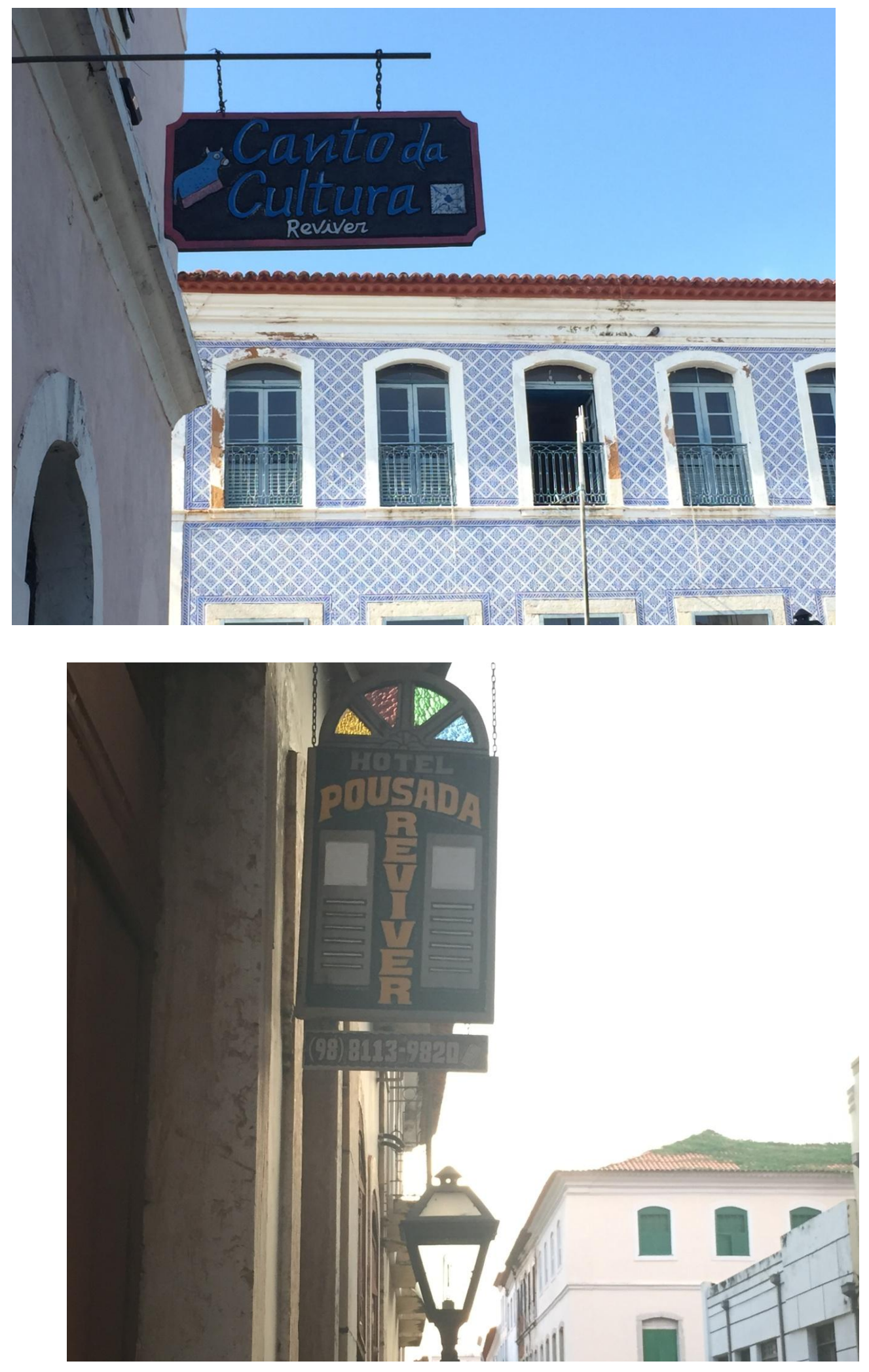



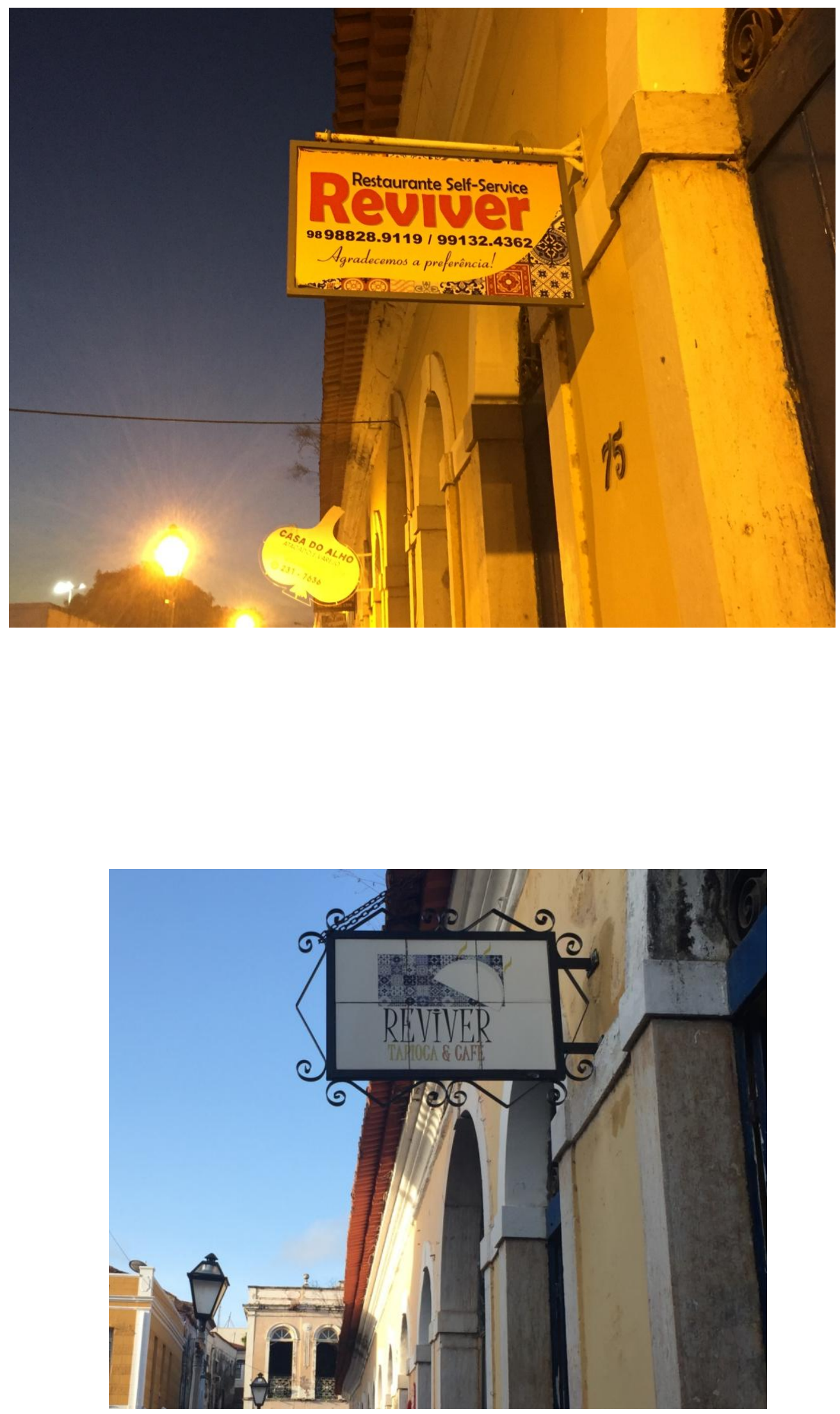

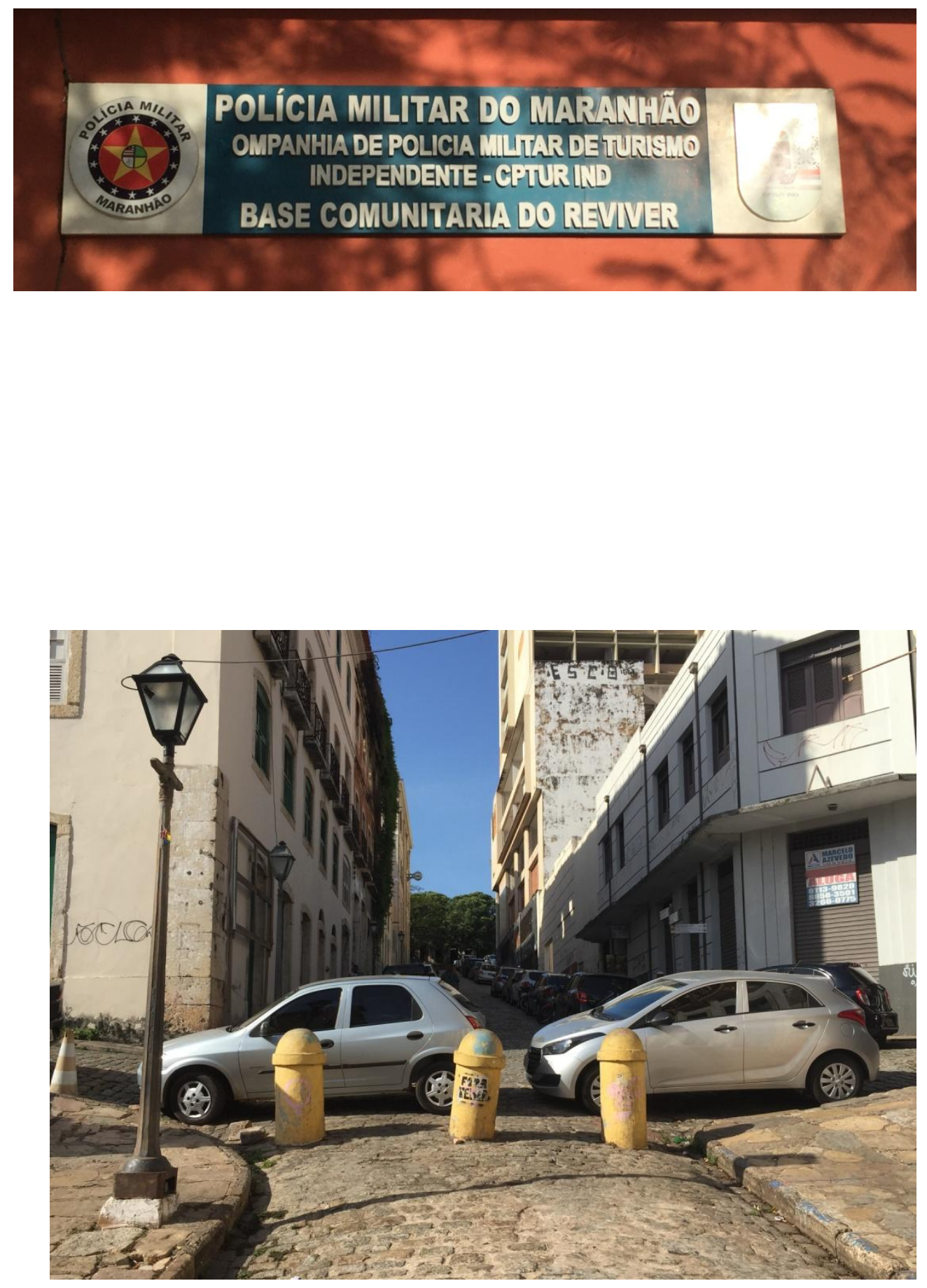

Interdições impedem os automóveis de passar para a área reconstruída pelo Projeto Reviver 




O título de patrimônio mundial é gravado nos postes desenhados à moda dos lampiões antigos.

No entanto, há também grafites e pichações que imprimem seus sentidos imagéticos sobre a paisagem urbana, constituindo uma política da imagem ${ }^{18}$ particular.

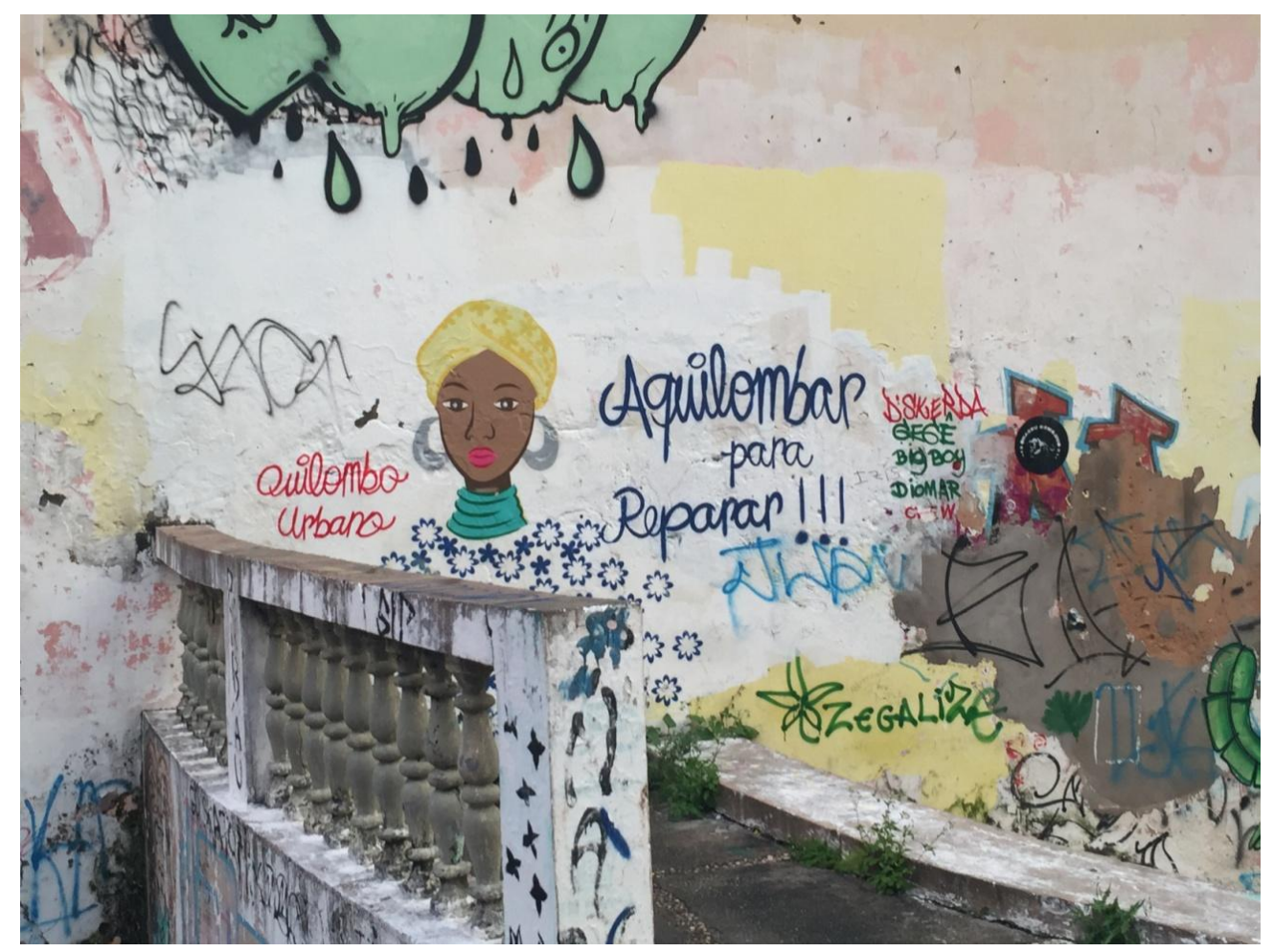

${ }^{18}$ Esta e outras categorias analíticas que aparecem neste capítulo serão melhor discutidas mais à frente (cf. p. 64). 

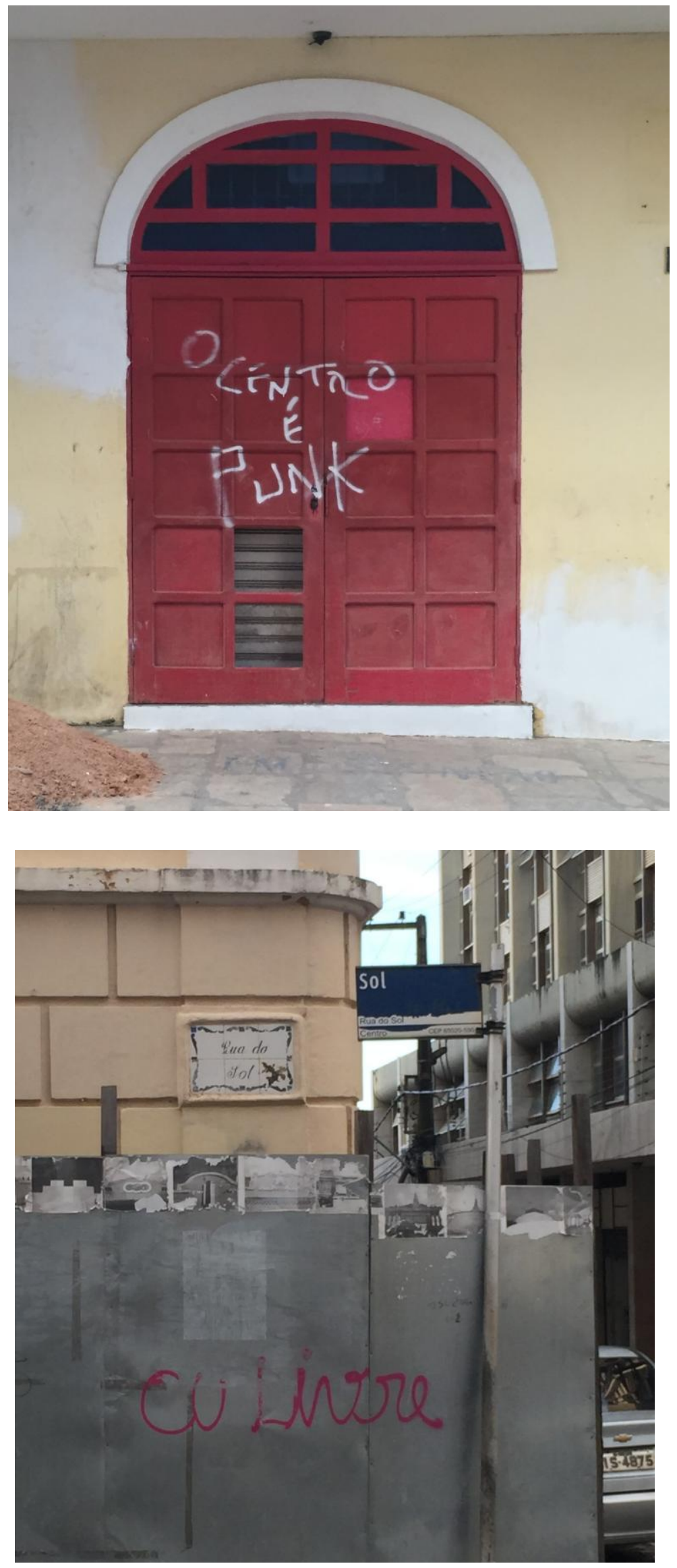


\section{Avenida Beira-Mar}

Tarde, terça-feira, abril de 2017.

O antigo prédio do Tesouro Provincial, construído em 1873, foi refuncionalizado no início dos anos 2000 enquanto Casa do Maranhão, reinaugurada em 2014 como "Centro de Interpretação Turístico-Cultural Casa do Maranhão”. Possui uma exposição extensa, com texto, imagens e artefatos, que apresenta a identidade local passando por temas como a fundação de São Luis, as religiões afro-maranhenses, "fazeres, ofícios, sabores e tambores", a consagração como Patrimônio Mundial, literatos e membros da Academia Brasileira de Letras, o reggae e as lendas regionais. No folder de apresentação distribuído na recepção, se lê:

No Centro de Interpretação Turístico-Cultural Casa do Maranhão, o visitante tem um roteiro completo para apreciar um Estado brasileiro de características únicas, seja por sua geografia pré-amazônica, sua história, influências, tradições e turismo, seja pelo patrimônio cultural e natural. [...] [S]obrevoe a capital e seus contornos, conheça os primeiros mapas e percorra as ruas do Centro Histórico, suas principais edificações a atrações. Verá que não é à toa que São Luís recebeu o título de Patrimônio Mundial. A arquitetura colonial das ruas e sobrados centenários faz desse pedaço do Maranhão o conjunto urbano mais importante do gênero no país. [...] Aproveite para comparar passado e presente. Veja como é possível crescer e preservar!

Um guia da Casa, estudante de turismo da UFMA (Universidade Federal do Maranhão):

Como aluno universitário, estudante do curso de turismo, e como eu tenho um certo conhecimento nisso, às vezes acaba me incomodando porque as pessoas digamos que não sabem o porquê do nome [...], ninguém sabe a história que tá atrás, que foi um projeto, que teve um certo tempo que ficou pra revitalizar o centro histórico e acabou terminando, e o nome acabou pegando, e acham que o centro histórico tem esse nome de Reviver, mas na verdade não, é centro histórico ou então bairro da Praia Grande. [...] Muita gente não sabe o que foi o Reviver, acha que Reviver é o nome do centro histórico: 'Ah vamo pro Reviver, vamos pro 'Revs'. Tem um certo incômodo porque como aluno de turismo eu estudo marcas turísticas, coisas 
pra vender o Estado, vender uma parte de um território de alguma cidade. Por exemplo aqui, o centro histórico, São Luís é vendida pelo centro histórico, São Luís não é vendida pelas praias, não é vendida pela vida noturna, é vendida pelo centro histórico, por essa nomenclatura de patrimônio histórico e cultural da humanidade. [...] Digamos que tinha que ter uma certa educação desde os níveis mais básicos pra ensinar educação patrimonial, ensinar o que é patrimônio, o bumba-meu-boi, que é patrimônio imaterial, o tambor de crioula, os mais de 3.500 casarões aqui que são tombados... E essa educação teria que ser utilizada justamente pras crianças crescerem já sabendo 'não, aqui era o Reviver, mas é o centro histórico'. Tem 405 anos de história aqui nessas ruas pra ser chamado de 'Revs', aí é sacanagem. [...] Só se movimenta aqui a partir de quinta-feira, quinta, sexta, sábado... [Menciono outras áreas do centro histórico, como a Rua Grande, de intenso comércio popular.] É, lá a semana inteira tem gente, eu falo mais dessa região aqui mais perto da Praia Grande. A Rua Grande é mais utilizada pra comércio, e por essa utilização, ter grandes lojas, tem um fluxo maior de gente. Aqui como não tem, é mais casarões, e bares, órgãos estaduais, museus, e lojas de artesanato, não vai ter um grande fluxo de pessoas pra loja de artesanato. [...] Eu vejo mais um público mais jovem, de adolescente, até 20 e poucos anos circulando por aqui. É mais comum ver aqui pessoas que a gente chama de 'descoladas', né. Tem essa interação com o espaço, de certa forma, porque nem todos vêm aqui 'ah vamos ali na rua tal'. Vem aqui no 'Revs' todo dia e tá aqui só por estar, só pra participar de um grupo social, de uma parcela de um grupo social'.

\section{Beco Catarina Mina}

Fim de tarde, sexta-feira, abril de 2017.

Um professor do curso de teatro da UFMA, sentado na entrada de um prédio da universidade:

[Chamo de] Dois nomes, né? Geralmente quando eu trato com pessoas de fora chamo de centro histórico, mas comumente aqui é Praia Grande né? Reviver eu chamo menos. [Muita gente] Chama por causa do projeto, que era Projeto Reviver, mas eu chamo mais de Praia Grande, talvez pelo fato de morar aqui. O Reviver teve um projeto de reformulação do centro histórico, 
e o nome era esse, e aí ficou. Eu costumo vir porque é um dos lugares da cidade em que eu me sinto bem, confortável, pra relaxar, pra beber... É um dos espaços de lazer que eu mais exploro na cidade. Mesmo quando eu não morava no centro era um dos espaços de lazer que eu mais explorava. Eu gosto de andar pelo centro. Tava na minha rota de lazer... sempre esteve na verdade. [Aqui] É um público alternativo. Alternativo no sentido que tá procurando outras alternativas culturais, pra além da cultura de massa. Então é você poder sentar em um lugar e ouvir um chorinho, ouvir um reggae, um tambor de crioula. Então tá muito ligado a um lugar específico da cultura, de um clima cultural. É diferente por exemplo de ir pra um outro lado da cidade, quando eu vou eu quero ir pra um pub, uma boate, eu quero ir pra um barzinho de rock... se eu vou pra lá, eu saio pra ir pro bar, eu não saio pra contemplar. Aqui eu tenho uma relação contemplativa. Às vezes eu venho pra cá pra caminhar. E se tu for por exemplo pegar outras pessoas que moram pelo centro, que vêm aqui costumeiramente, [dizem] 'não, a gente vai só passear, vai andar, vai observar...'. Aqui é um espaço histórico que a gente tá, né, é um espaço de quatrocentos anos, então... é diferente de ir pra outro lado da cidade. Em outro lado da cidade você tem um objetivo muito traçado. Aqui é o fator cultural e histórico, das práticas culturais que aqui existem, dos hábitos culturais, do tempo, do clima da Praia Grande. Mas é porque é um espaço de boemia, que concentra os teatros da cidade, que tem o cinema alternativo... [...] Mas por exemplo, da vivência que eu tenho daqui do centro histórico, dos moradores que eu conheço daqui do centro histórico, existe um prazer muito grande de morar na Praia Grande, ao mesmo tempo é muito difícil porque... é muito mal-tratado, o centro em geral. As pessoas esperam que você tenha uma conservação muito maior, como você tem na Lapa, não tô nem falando de questão turística, tô falando de conservação mesmo, como se tem em Salvador, outros lugares históricos do Brasil, Olinda... ainda falta muita gestão pública pra organizar o espaço. Ainda assim as pessoas não querem sair daqui. 


\section{Praça Nauro Machado}

Fim de tarde, sexta-feira, abril de 2017.

Essa praça é um importante espaço de visibilidade da cidade, sendo frequentemente sede de eventos como shows musicais. Nesse dia, vários jovens bebem cerveja e destilados em copos descartáveis de plástico, fumam, jogam cartas e falam alto, sentados nos bancos e na escadaria. Alguns casais homossexuais expressam afeto publicamente (cena incomum em outros territórios da cidade). Na lateral da praça, várias vendedoras ambulantes, em sua maioria mulheres, comercializam bebidas. Em um outro lado, sobre os paralelepípedos da Rua da Estrela, dois policiais militares observam em pé o movimento. Em um dos bares que há em volta da praça, um garçom tira cadeiras e mesas de uma pilha e as dispõe na calçada, indicando início de expediente. Apenas uma presença se diferencia mais eloquentemente da rede do lazer: um catador de latas muito magro se ajoelha no exato centro do descampado, se benze e levanta os braços, olhando para o céu. Logo em seguida se levanta e se retira sem olhar para trás, apenas parando para cumprimentar uma ou duas das pessoas sentadas, que parecem não o reconhecer.

Aos poucos, principalmente no início da noite, os bares começam a encher e tocar música com o auxílio de caixas de som. Os estilos variam entre reggae, rock, forró.

Uma senhora idosa sentada na frente de um dos bares diz que costuma fechar o seu à meia-noite:

Até doze horas ainda tá tudo certo, é mais seguro, mas se ultrapassar, aí... [...] É arriscado, tem muito maluco aqui, muito ladrão....

Início da noite, quinta-feira, abril de 2017.

O movimento é ainda maior. Há um número grande de adolescentes sentados na escadaria, alguns com uniforme escolar do Liceu Maranhense, tradicional escola pública da cidade. Um pouco ao lado, na Rua da Estrela, um grupo de músicos de rua atrai a atenção dos passantes: é um conjunto formado por um homem e uma mulher adultos, e três ou quatro crianças de cabelos longos, que cantam e tocam no violão, pandeiro, chocalho e escaleta um repertório que vai de Belchior e João do Vale a Bob Marley. As calçadas já estão ocupadas por mesas com pessoas bebendo cerveja. Em um dos bancos da praça, um grupo de jovens 
brancos de calça jeans bebe cachaça artesanal em copos de plástico. São estudantes de engenharia; um deles diz estar se formando em engenharia elétrica. Ouço outro dizendo: "vou pegar uma cerveja que eu não tô nem aí”. Os bares da rua que margeia a praça tocam tipos de música diferentes: há Legião Urbana em um, e outro, poucos metros ao lado, toca canções bregas como Você Não Me Ensinou a Te Esquecer e Brigue Comigo Mas Não Vá.

Meio da tarde, segunda-feira, abril de 2017.

A paisagem humana do mesmo lugar é bastante diferente: poucas pessoas transitam, e as que o fazem parecem ter destino fixo, pois apesar de tranquilas, e até mesmo vagarosas, não se detém e caminham em direções específicas. Algumas portam mochilas e outras estão vestidas com roupa social (a região também concentra uma série de órgãos e repartições públicas, como a Secretaria de Cultura, a superintendência regional do IPHAN, a Defensoria Pública do Estado e uma agência grande dos Correios). As vendedoras ambulantes ainda estão, mas em menor número. Apenas uma roda de jovens, com uniforme escolar, ouve música no celular e acompanha no violão músicas brasileiras recentes, como Amor Marginal, de Johnny Hooker.

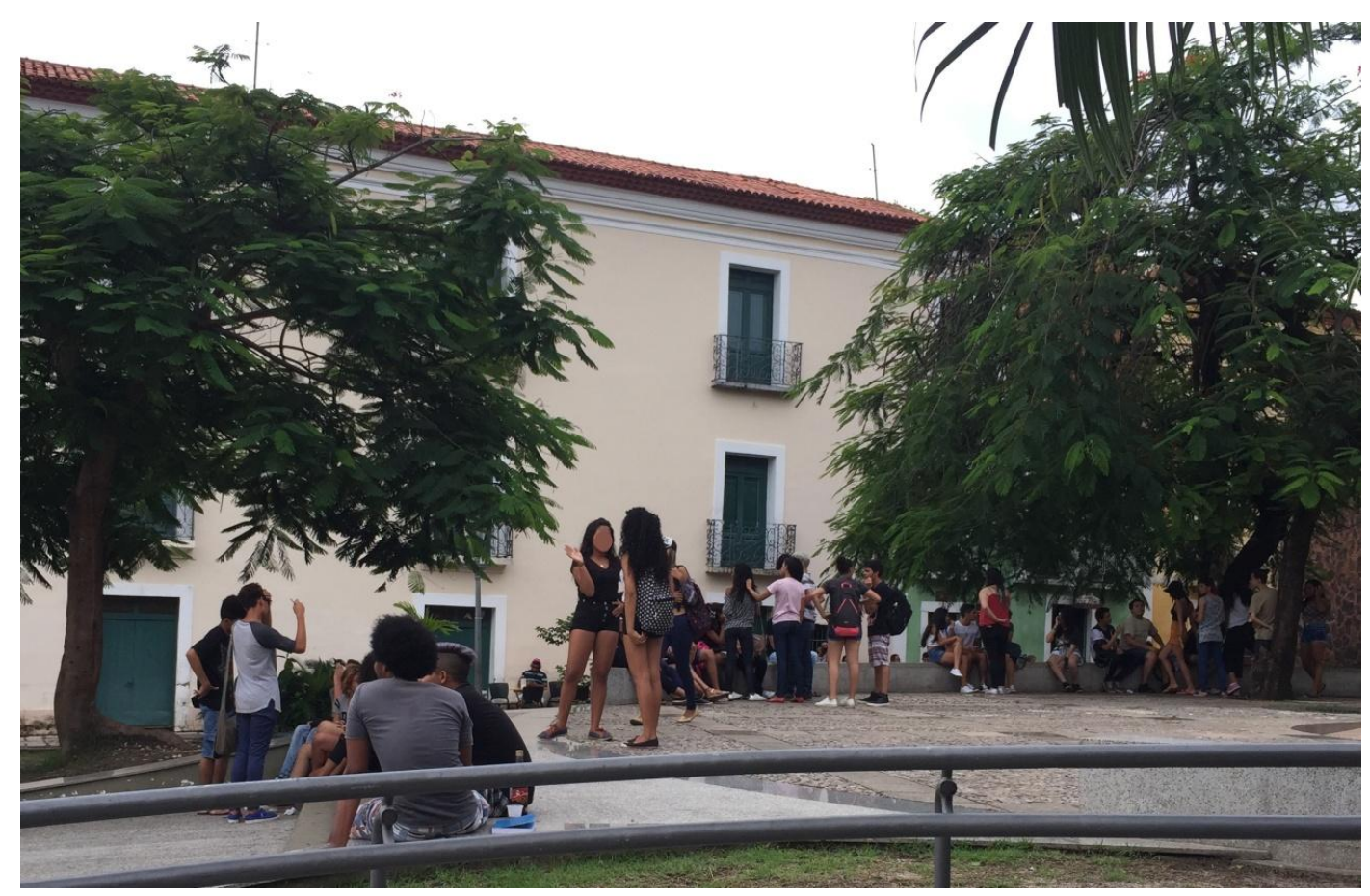

Adolescentes socializando na Praça Nauro Machado 
Noite, sexta-feira, junho de 2017.

Durante um dos arraiais promovidos todos os anos por governo estadual e prefeitura, em função dos festejos de São João, um grupo de cerca de quinze jovens evangélicos, vestidos de branco, toca violão e canta no início da rua que dá acesso à Praça Nauro Machado, e à Praia Grande em geral. A poucos metros da praça, onde se apresenta um grupo de bumbameu-boi, os religiosos chamam atenção de quem passa chegando ao arraial, constituindo uma apresentação paralela que visualmente em nada tem a ver com o grupo de boi, com suas matracas e pandeirões, suas plumas coloridas e brincantes fantasiados de vaqueiros, caboclos e índios.

Rogério Proença Leite observa, a respeito do Recife Antigo:

No Domingo na Rua, ao fim da tarde, várias apresentações dão o tom cultural ao evento: desfilam pela rua do Bom Jesus grupos de Bumba-meuboi, Maracatu, Caboclinhos. Essas apresentações ocorrem, obviamente, na forma alterada de espetáculo, bem diferente das demoradas festas populares que caracterizam essas manifestações da cultura nordestina. [...] A convite da Prefeitura, que paga uma quantia (não revelada), os grupos tinham grande interesse em se apresentar no Bairro do Recife, segundo informou um dos integrantes do grupo Maracatu Carabinda Dourada. [...] Parece claro, de outro modo, que havia um esforço da Prefeitura em configurar o Bairro como um local onde se podia ter contato com a tradicional cultura popular pernambucana. Mais do que isso: o encontro entre o patrimônio edificado (e restaurado) com essas expressões imateriais do patrimônio cultural configuraria a tentativa de re-localização e afirmação de uma tradição, através da qual se buscava reinventar centralidades de um espaço da cidade.

[...] Consumidos como espetáculos-mercadorias, as apresentações da cultura popular no Bairro do Recife pretendiam mediar as relações entre as práticas de consumo e a re-significação tradicional do local que legitimariam o 'mercado da autenticidade' (Fortuna, 1998) no qual está inserido o Bairro, na busca da afirmação dos bens culturais com os quais pretendia construir sua singularidade. (LEITE, 2001, p. 260-262) 


\section{Praça do Pantheon, em frente à Biblioteca Pública Benedito Leite}

Meio da tarde, quinta-feira, outubro de 2017.

E os templos e as grimpas soberbas,

Palácio ou mesquita preclara,

Que a foice do tempo poupara,

Em breves momentos é pó.

Gonçalves Dias, A tempestade

A área é comercial: agência da Caixa, do Banco do Brasil, clínica de raio X, ótica. A praça possui em suas laterais vários quiosques de comércio que vendem bolsas, água, açaí, batata frita, chiclete, capinhas para celular de todo tipo. Intensa circulação de pessoas e ônibus. No chão há colchão, travesseiro, cobertores, pedaços de papelão, o que indica que ela é habitada por pessoas em situação de rua. No entanto, os donos ou usuários desses objetos estão ausentes. Um homem com uma mochila grande ao lado mostra, dispostas em um tabuleiro, as pulseiras e bijuterias que vende, a um passante que está de bermuda e havaiana.

O logradouro se chama Praça do Pantheon porque apresentava, dispostos sequencialmente em um retângulo, dezoito bustos de escritores maranhenses. Trata-se, em suma, de uma homenagem aos expoentes da tradição intelectual e literária local. No entanto, desde 2007 as estátuas não se encontram mais lá. Como explica uma reportagem de fevereiro de 2016, da versão eletrônica do jornal $O$ Imparcial ${ }^{19}$, os bustos "foram retirados da Praça do Pantheon por causa da ação de vândalos e da falta de segurança. Por conta disso, foram transferidos e guardados no Museu Histórico e Artístico do Maranhão (MHAM), localizado na Rua do Sol”. Dessa forma, o que se vê é uma série de pedestais vazios, em frente à Biblioteca Pública Benedito Leite, criada em 1826, mas transferida para o atual local em 1951, quando foi inaugurado o prédio neoclássico de paredes brancas que lhe serve de sede.

19 https://oimparcial.com.br/noticias/cidades/2016/02/bustos-da-praca-do-pantheon-devem-voltar-ao-local-aposreforma/. Acesso em 27/10/2017. 


Uma senhora, podóloga, de camisa branca e coque apertado:

Infelizmente o centro histórico tem deixado a desejar, violência demais, não tem tido o zelo adequado em relação a tudo, os casarões estão se destruindo. [...] $\mathrm{O}$ foco do centro histórico, mesmo, que a gente vê, exatamente o Reviver ${ }^{20}$, perto do Palácio dos Leões... Teve uma época realmente que era mais seguro, tinha mais... os nossos representantes davam mais atenção. Cuidavam mais, investiam em algum tipo de reconstrução de alguma coisa, mas ultimamente tá largado 'pras cobras', como dizem na história. [...] Eu lembro que quando eu comecei a visitar mesmo, ainda tinha algumas estátuas. Ali eu lembro que tinha uma... Se eu não me engano era... eu sei que era um senhor, eu não lembro o nome agora exatamente. Acho que tá com uns onze anos... decapitaram a cabeça. Infelizmente a nossa cidade tá à mercê de bandidos, de vândalos, na verdade. Infelizmente a droga, as drogas na verdade tá sendo a destruição do mundo, você vê, antes era muito raro tu ver um mendigo, hoje em dia tu vê muitos mendigos, jovens, na verdade, destruindo a vida por conta de drogas, e a droga dá coragem de destruir, de tirar a vida de alguém... Aqui tem muito vândalo e usuário de drogas, na verdade. Porque se tu andar no centro histórico, tu vê muitos usuários de drogas. E são eles que cometem assalto, que matam, que roubam, que destroem. No centro inteiro. Só que por conta de no centro histórico ter muitos casarões abandonados, no centro histórico você vê mais, porque eles têm mais espaço pra dormir, pra se esconder, enfim, que em outros lugares eles não têm.

O cenário e o relato fazem refletir sobre o modo como a pomposa história da Atenas Brasileira, tão registrada nas páginas dos livros e jornais, encontra sua duração em política da imagem (da qual a depredação também faz parte): pedestais vazios e “um senhor” decapitado.

\section{Praça da Faustina}

Meio da tarde, segunda-feira, outubro de 2017.

Caminho da Praia Grande ao Desterro, e depois de volta à Praia Grande, mais de uma vez. Vejo um casal tirando fotografia com os sobrados azulejados da Rua Portugal,

\footnotetext{
${ }^{20}$ Note-se que ela se refere espontaneamente à Praia Grande como "Reviver".
} 
provavelmente o principal cartão-postal da região. Durante a caminhada também ouço um outro casal falando em inglês, mas são os únicos turistas claramente identificáveis enquanto tais que vejo. Na Praça da Faustina, encontro um amigo por acaso. Digo que estou indo sacar dinheiro no Banco do Brasil mais próximo, que fica na Praça Pedro II. Ele me acompanha enquanto colocamos o assunto em dia. Na volta para a Praia Grande, descendo pelo Beco Catarina Mina, passamos em frente a um prédio com uma placa que indica: "Casa de Cultura Huguenote Daniel de La Touche". Meu amigo diz que nunca antes ter visto esse espaço, e demonstra curiosidade. Entramos. Um guia jovem nos recebe e apresenta a casa. Diz que já dura mais de três anos e nasceu de uma iniciativa privada, e que se mantém sem qualquer apoio do Estado. No térreo, há uma exposição de pinturas com a temática da fundação da cidade de São Luís. São cenas da vida indígena, com apenas uma delas apresentando um conjunto de caravelas.

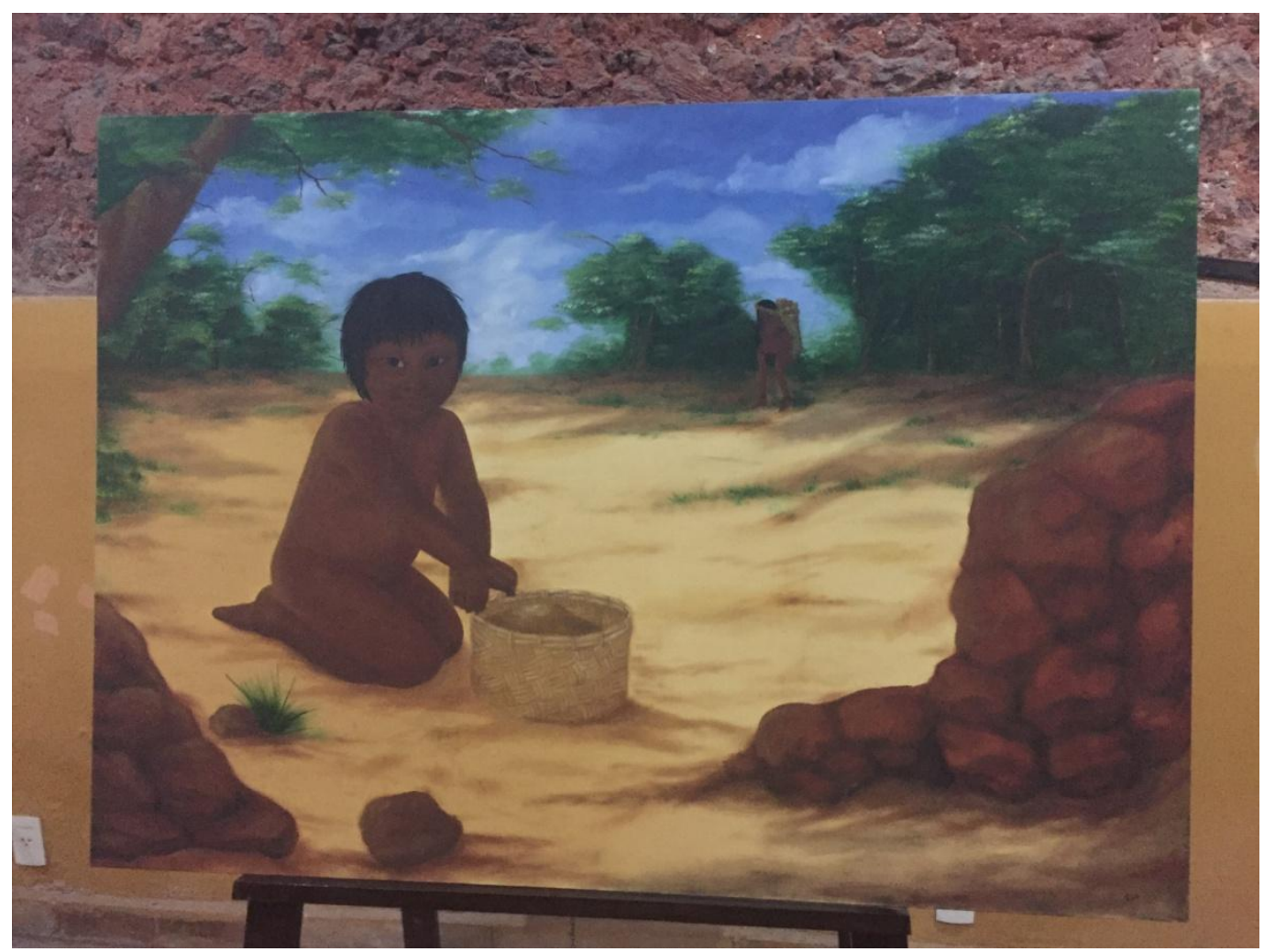




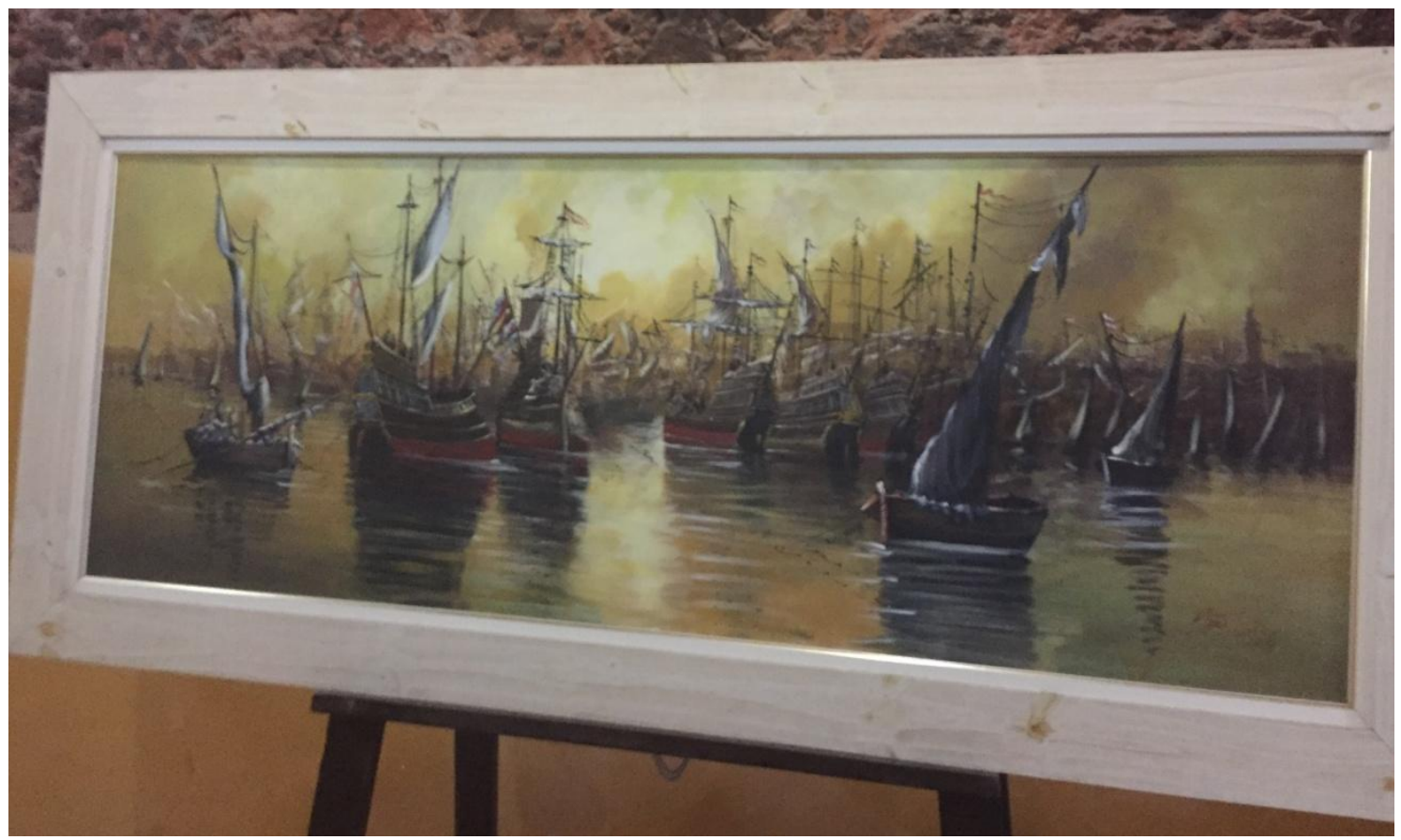

Pergunto ao guia se ali são oferecidos cursos de pintura, e ele responde que não, que as telas foram feitas através do "dom”. São dois os artistas ali expostos. Atrás da exposição, no fundo, há um café que vende salgados e bebidas. Nosso anfitrião nos convida a subir ao segundo andar, onde nos conta em detalhe a história do cristianismo, da Antiguidade à Reforma Protestante, com a ajuda de um painel. Narra também as origens da cidade de São Luís, ressaltando o papel do fundador Daniel de La Touche, homenageado da casa e ele próprio um huguenote. $\mathrm{Na}$ narrativa apresentada, os protestantes não compartilhavam do dogma católico segundo o qual negros e índios não possuíam alma, e a fundação de São Luís teria sido apoiada pelos tupinambás, que se aliaram aos franceses contra os portugueses, chegando mesmo a sugerir uma "confraternização" entre os dois grupos étnicos. Há também uma bandeira alemã, e o guia me diz que ali funcionam cursos de línguas como inglês, francês e tupi, este último ministrado por um professor indígena. Pergunto o que funciona no segundo andar e ele diz que é uma sala de oração.

Depois da visita, meu amigo me conta que antes ali funcionava uma boate gay. Sentamos na Praça Nauro Machado, em cuja escadaria há uma faixa comemorando os 500 anos da Reforma, e ele se voluntaria para ajudar na pesquisa: 


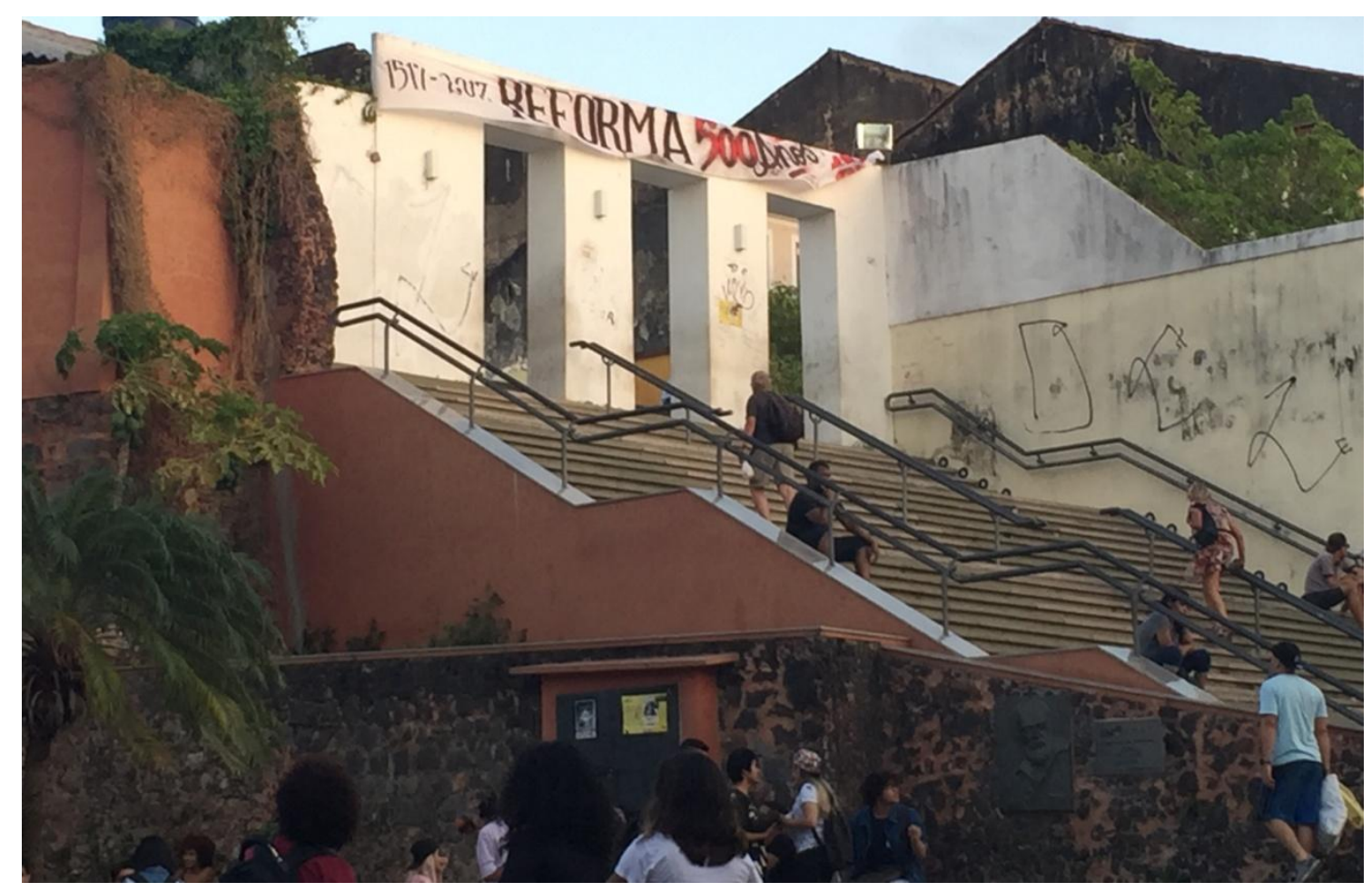

Frequento porque eu acho interessante essa proposta... essa atmosfera da cultura, que eu acho que é mais viva aqui, no centro histórico, essa variedade de atividades ligadas à cultura aqui, e também porque dentro da logística da minha vida ela é elemento presente, porque eu estudo na Universidade [Federal do Maranhão], então sempre que eu vou pra universidade eu tenho que passar por aqui, porque eu tenho que passar pelo terminal, e sempre que eu volto da universidade eu passo por aqui. Então tem essa questão logística do descer às vezes, quando tá engarrafado, pra fazer hora aqui até o trânsito melhorar. E também porque eu acho que é um espaço muito frequentado pelos estudantes universitários, e aí eu acabei vindo por osmose também, meus amigos sempre vêm, eu comecei frequentando porque meus amigos vinham, me convidavam, e eu comecei a gostar. [...] Eu diria que é o público mais variado de São Luís o do centro histórico, porque você tem turistas, você tem estudantes secundaristas, tem o pessoal mais velho também, né, que frequenta a feirinha, que eu acho que é um outro mundo, assim, eu sempre chamo a feirinha de um mundo paralelo. Dentro da feirinha tem brega, tem música antiga, tem bolero, tem de tudo lá. E aí o pessoal mais antigo que sai do trabalho também geralmente encosta aqui e fica lá. [Pergunto sobre a paisagem.] Tem uma publicidade do turismo que transformou o centro histórico na cara de São Luís, né, também, mas tem 
essa coisa da gente conseguir visualizar os elementos históricos, tipo os azulejos, a arquitetura, as sacadas... e tem os espaços públicos que você pode sentar e conversar, a escadaria que foi transformada em um espaço de lazer. E os bares né? [...] Pois é, e na sexta por estar um pouquinho mais violento, "um pouquinho" bastante, eu já presenciei, eu tenho evitado vir nas sextas aqui, porque eu acho que um grande volume de pessoas facilita também os assaltos. [...] Então eu decidi que não seria mais a minha programação de sexta-feira. Mas a quinta, que é a nova sexta [risos], na quinta tem o projeto do festival do reggae ali na praça, na outra praça, da Criança, tá bacana lá, e eu acho que foi legal também porque deu visibilidade pra um outro espaço que tava subutilizado aqui, que era um espaço que o pessoal ia usar droga lá. E é legal porque é um reggae que une o pessoal de todas vertentes aí, desde o roots até o reggae de radiola mesmo...

Meio da tarde, segunda-feira, novembro de 2017.

Uma semana depois, no mesmo lugar, passa lentamente por mim um grupo de cerca de 15 senhoras de meia idade e idosas, na direção da Praça da Faustina, orientadas por um guia turístico. No grupo das turistas há apenas um homem, que parece ser cônjuge de uma delas. Uma delas para para fotografar e fica um pouco para trás em relação ao grupo. Aproveito para perguntá-la de onde são. "De Juazeiro da Bahia.” O guia apresenta a Praça Nauro Machado ao grupo: "aqui é um espaço de lazer e é um espaço democrático, aqui muita gente diferente vem, vem desde o morador ali da Península [da Ponta d'Areia, bairro "nobre"], até o morador da periferia, e todas as tribos se entendem...”. Chegando à praça da Faustina, ele diz que o nome da praça é como uma "memória viva" da última cafetina da região, falecida há alguns anos. Conta que na época do Projeto Reviver as casas de prostituição foram retiradas da área, porque a proposta era de "moralizar" o lugar. Uma das senhoras pergunta a respeito do sobrado em ruínas logo em frente à praça. O guia responde que "muitos prédios pertencem a particulares, e muitos não tem dinheiro ou interesse em mantê-los", completando que "aí o IPHAN manda escorar". Observo o prédio. Sobre a intervenção emergencial do IPHAN, com o objetivo de manter de pé aquela imagem, a cartomante Ana de Iemanjá deixou seu telefone. 

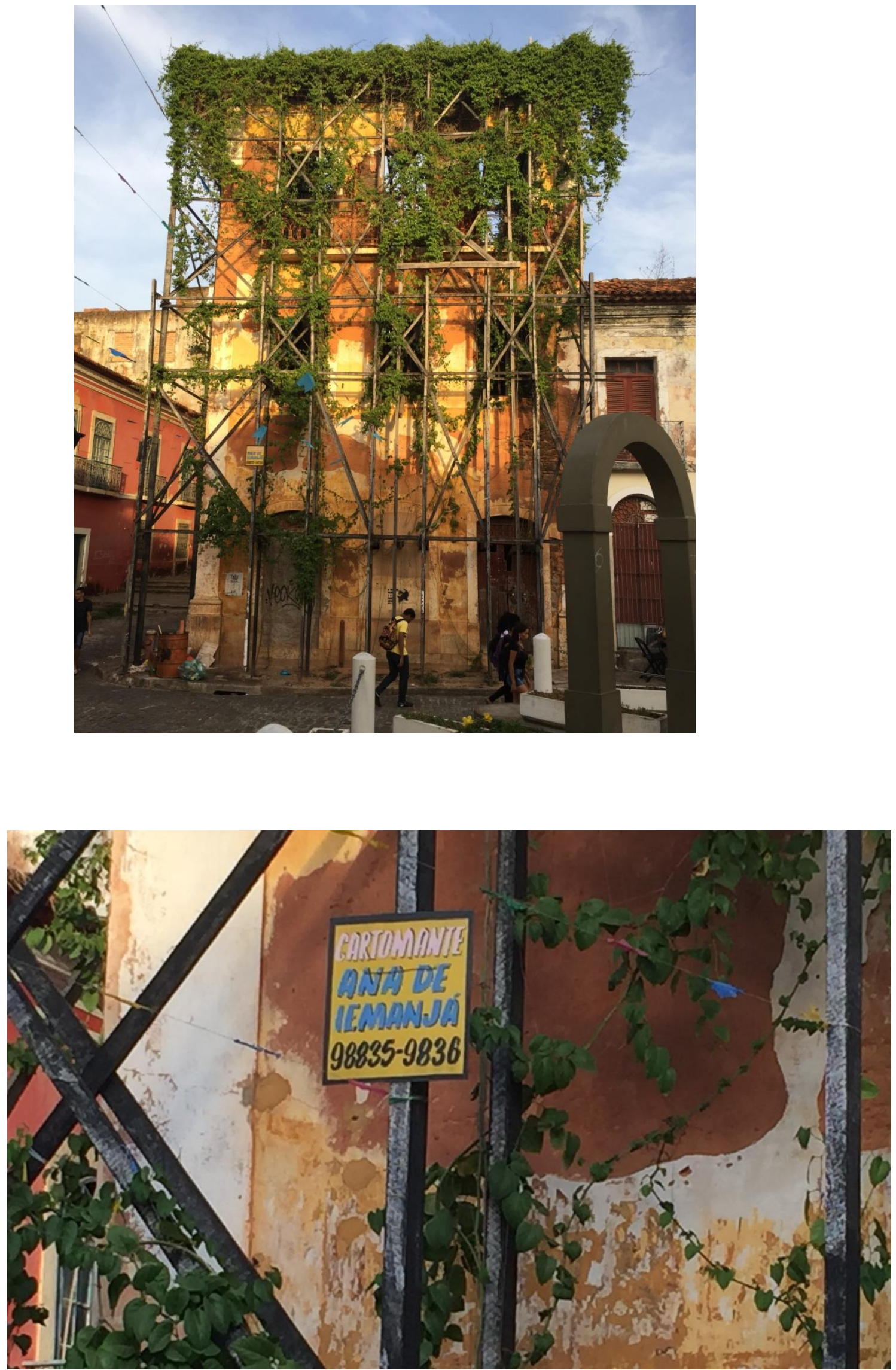


\section{Rua do Trapiche, ao lado da Casa do Maranhão, Praia Grande}

Fim de tarde, terça-feira, novembro de 2017.

Uma senhora, vendedora ambulante, vestida com saia longa de estampa florida e faixa no cabelo:

O centro histórico... os prédios precisam de muita reforma. Tá precisando. Agora a paisagem, como eu trabalho de frente pra praia, então eu acho ótimo, né? Tem o pôr-do-sol, maré cheia... mas os prédios precisam de muita reforma. Não tá bacana não. Precisando o governo dar uma olhada. Você observa que tá todo destruído, cheio de mato na fachada... Eu venho mais por trabalho. Já trabalho aqui há dezesseis anos. Mas é mais trabalho mesmo, porque pra passear não dá não. Porque eu já tô aqui todo dia, né... aí já enjoei. Quinze anos no mesmo lugar, todo dia, de segunda a segunda... O centro histórico é frequentado por muito turista, na alta temporada. Vem pro São João, Carnaval, nas férias. Aí depois termina a alta temporada e é o povo daqui mesmo. Sexta-feira o pessoal vem, toma uma cervejinha, nos barzinho, curtir um reggae, quem gosta... Mais jovem. Às vezes eu vou no rock mas eu gosto mais é do reggae roots. Eu vou mais na rotatória [do Bacanga, no anel viário que circula o centro da cidade], eu gosto mais de lá. Ou então no Porto Seguro, que tem um agarradinho ${ }^{21}$ na quinta-feira. É ao lado do Mercado do Peixe [também no lado de fora do anel viário]. Aqui no centro histórico eu não gosto. Mas aqui também tem. Mas é porque aqui sexta-feira é um pouquinho... [olha para os lados]. Não gosto por causa da violência. Até que melhorou um pouco, porque sexta-feira passada teve muito policiamento, tinha o pessoal com a viatura aqui na rua... mas é que sexta-feira é um pouquinho violento. [Pergunto sobre o reggae da praça da Criança, mencionado na página 40.] Tá tendo também o reggae da praça. Já fui. Gostei mais ou menos. Não gostei muito do público daquele reggae. Esse reggae ali da praça tem muita droga, não dá pra mim também. É bacana pra quem gosta, né? Mas pro meu estilo, dali eu não gostei. Eu fechei aqui minha barraca, fui com meu marido ali pra dar uma volta, cheguei ali e meu amigo, ali a fumaça é muito forte. Aí não deu pra mim... [risos]. Na rotatória não tem não. Lá é fechadinho, tudo padronizado, tem ar condicionado, entendeu? [Pergunto se é pago.] É, quinze reais.

\footnotetext{
${ }^{21}$ Maneira específica de se dançar o reggae no Maranhão, lentamente e em dupla.
} 
Começo de madrugada de sexta-feira para sábado, novembro de 2017.

\author{
Pra ver do alto a fila de soldados, quase todos pretos \\ Dando porrada na nuca de malandros pretos \\ De ladrões mulatos e outros quase brancos \\ Tratados como pretos \\ Só pra mostrar aos outros quase pretos \\ (E são quase todos pretos) \\ E aos quase brancos pobres como pretos \\ Como é que pretos, pobres e mulatos \\ E quase brancos quase pretos de tão pobres são tratados \\ Caetano Veloso, Haiti
}

Estou sentado em uma mesa ao ar livre, de um dos três bares funcionando na rua, a poucos metros de onde a interlocutora anterior monta sua barraca. De dentro de um deles sai um reggae intenso, que é o som predominante em todo o ambiente. No entanto, outros ruídos menores também se difundem. Pessoas conversando e outras fontes de música, caixas de som menores e dispersas, também podem ser ouvidas. As mesas dos três bares, que se misturam, estão lotadas, e também há vários grupos em pé. Além do movimento de vai e vem dos garçons que servem as mesas, há vendedores ambulantes que oferecem três cervejas a dez reais, além de vinhos e destilados (São Braz, Catuaba, Caninha do Engenho). O público é majoritariamente jovem e negro. Em pé, os grupos de jovens do gênero masculino se sobressaem; entre eles, aparentemente, a vestimenta da moda é bermuda jeans ou de tactel, camisa colorida de gola polo e boné de aba reta. Também é comum ver com indivíduos isolados, mas principalmente com os rapazes em grupo, pequenas garrafas de plástico que passam de mão em mão repetidamente, parcialmente cheias com um líquido transparente que eles aspiram, uns disfarçadamente, outros nem tanto. Uma pequena parte das pessoas fuma, com o tabaco predominando sobre a maconha, embora exista o cheiro desta última. Após o álcool, o loló é de fato a droga mais visível. Pergunto de forma despretensiosa aos outros três integrantes da mesa em que estou como eles identificariam o público dali. O namorado de minha amiga dá uma definição socioespacial: "é um pessoal que mora mais da ponte pra cá" (isto é, do lado do centro, e não do lado das praias). 




Uma viatura policial, com a luz vermelha piscando, passa repetidamente pela rua em frente aos bares, que é interditada aos automóveis comuns, obrigando a multidão a se afastar para dar passagem ao carro, e voltar a suas posições iniciais tão logo ele se afasta. Com menor frequência, alguns policiais armados também circulam a pé pelas laterais da aglomeração, sem realmente chegarem ao seu centro. No interior do bar do canto esquerdo, de onde vem a música mais alta, várias pessoas dançam em dupla, ao som do reggae cantado em inglês ou apenas instrumental, em um salão retangular. Na porta do bar do meio, dois avisos impressos em folha de papel A4 indicam que é proibida a entrada de menores de idade, e que a entrada para os homens custa dez reais, sendo gratuita para as mulheres. Dentro, é possível ver que há um jogo de luzes coloridas, que saem pelas portas e janelas.

Entro com um amigo no bar da esquerda, cuja entrada é livre, deixando minha amiga e seu namorado sentados na mesa. O salão é espaçoso e ocupado principalmente por uma caixa de som grande, pelos casais e por outras pessoas que dançam individualmente. $\mathrm{O}$ ambiente, à meia luz, está cheio mas não lotado. Acima da porta, há uma bandeira grande com o rosto de Bob Marley. Meu amigo encontra uma amiga sua e para para cumprimentá-la. Apresenta-nos e ficamos conversando um pouco e ouvindo o som, que dentro é bem mais alto, entre graves e agudos. 




Quando saímos da parte interna do bar e voltamos à mesa na calçada, nossos amigos ainda estão lá. Mas os mais de cinco rapazes que antes estavam na mesa ao lado, sem consumir, não estão mais sentados. Estão em pé, alguns com pernas abertas e mãos na cabeça, virados de frente para a parede do antigo prédio do Tesouro Estadual (cf. p. 28). Um policial militar apalpa seus corpos, suas virilhas e cinturas, e enfia a mão em seus bolsos, enquanto outro observa. As demais pessoas em pé apenas se afastam um pouco da parede, mas seguem bebendo e conversando. Com o canto do olho, espiam o espetáculo truculento. Depois do "teatro", não havendo os policiais encontrado nada a não ser pertences pessoais, os jovens se retiram, caminhando na direção do terminal de ônibus da Praia Grande. Na prática, expulsos. Lembro-me da canção de Gilberto Gil e Caetano Veloso que diz que o Haiti é aqui... o Haiti não é aqui...

Osmundo Pinho, em sua etnografia das identidades e territórios do Pelourinho, em Salvador/BA, afirma a respeito de um dos bares por ele analisados:

No interior deste aparato 'espetacular e barulhento' que é o Novo Pelourinho, os regueiros, como flâneurs negros, reinventam uma forma de consumo de espaço subvertendo a norma dominante e 'ameaçando a tranquilidade'. A dupla de policiais militares, postada na calçada em frente ao bar, vigiando os adolescentes é infalível. Além de que, regularmente 
(aproximadamente de trinta em trinta minutos), a fila de PM's carrancudos atravessa o espaço, secionando a aglomeração e certificando-se de que nada de perturbador está acontecendo. [...] [A] prática de espaço verificada no Bar do Reggae é uma estratégia de consumo cultural espacial que privilegia o uso dissimulado e transitório, não cria enfrentamentos, nem redige manifestos, mas se organiza, dá testemunho de sua diferença e de sua integração à legião de vozes da diáspora e não se intimida diante da polícia. (PINHO, 1996, p. 109; 113-114)

Para além do elemento repressivo, o autor interpreta os fluxos de sentido que se dão através do reggae pelas lentes da contribuição teórica de Paul Gilroy:

Paul Gilroy argumenta que poderíamos considerar o Atlântico Negro, espaço de formado pelos fluxos culturais e econômicos entre África, Caribe, América e Europa, como uma entidade analítica complexa e dinâmica que superaria diferenças nacionais e culturais. [...] A partir dessa formulação Gilroy propõe que se gestou no Atlântico Negro uma contracultura, contrainterpretação, da modernidade ela mesma. Gilroy sugere que o processo que criou o Negro, o Atlântico Negro e a diáspora, produziu suas próprias e específicas contradições. Assim, a música, as artes negras e o pensamento negro radical (político ou místico) são expressões da vertente contracultural crítica do Atlântico Negro [...]. (PINHO, 1996, p. 119; grifos do autor)

Assim, a hibridação aparece como paradigma de compreensão de processos sociais amplos e interligados, como modernidade e colonização. Citando ainda o caso da inserção do reggae maranhense nessa rede transatlântica, o autor pontua que

[o] reggae em São Luís é um fenômeno de massa e popular, atacado pelos setores de elite da sociedade local. Ora protestando contra a invasão de uma música estrangeira, ora acusando os regueiros e os bailes de violentos, a elite maranhense rejeitava profundamente a autonomia cultural dos negros de lá. (PINHO,1996, p. 122; grifo do autor)

Dessa forma, penso que essas passagens fornecem indicações para uma interpretação da posição de expressões como o reggae no interior da trama simbólica do centro histórico: como contracultura da modernidade - e, também, do processo de invenção do centro histórico -, mas ao mesmo tempo mutuamente implicadas com os fluxos de atribuição de sentido que serão analisados mais à frente. 


\section{Praça da Criança}

Noite, quinta-feira, novembro de 2017.

Uma semana depois, vou ao reggae dessa praça, onde uma sequência de DJ's apresenta seus sets em um palco pequeno. Aparentemente desta vez há mais estudantes, e também mais pessoas que parecem fazer do reggae seu estilo pessoal, com boinas e dreadlocks rastafári. Há sim consumo de maconha, mas não tão tanto quanto sugerido pela interlocutora da página 42. Talvez por ser quinta-feira, talvez por ser um evento onde parece haver a presença um pouco maior de uma classe média branca (embora nesse mesmo dia esse público estivesse mais concentrado na Praça Nauro Machado, a cerca de 200 metros, onde se apresentaria a banda paulista Francisco El Hombre), ou talvez por ser um projeto apoiado pelo governo do estado, a presença da polícia é bem menor, e se limita a uma dupla que por vezes se ausenta do espaço para fazer ronda nas ruas ao lado. A curadoria do projeto é de um conhecido produtor cultural da cidade, ligado há décadas ao meio do reggae. Os DJ's que o precedem movimentam uma pequena multidão, mas que permanece dispersa. Quando esse produtor entra, no entanto, se cria uma aglomeração em frente ao palco e há uma empolgação maior. Acho compreensível, pois o set é excelente. Abaixo, no anfiteatro que há na lateral da praça, a marca Jamaica Stilus vende seus produtos.

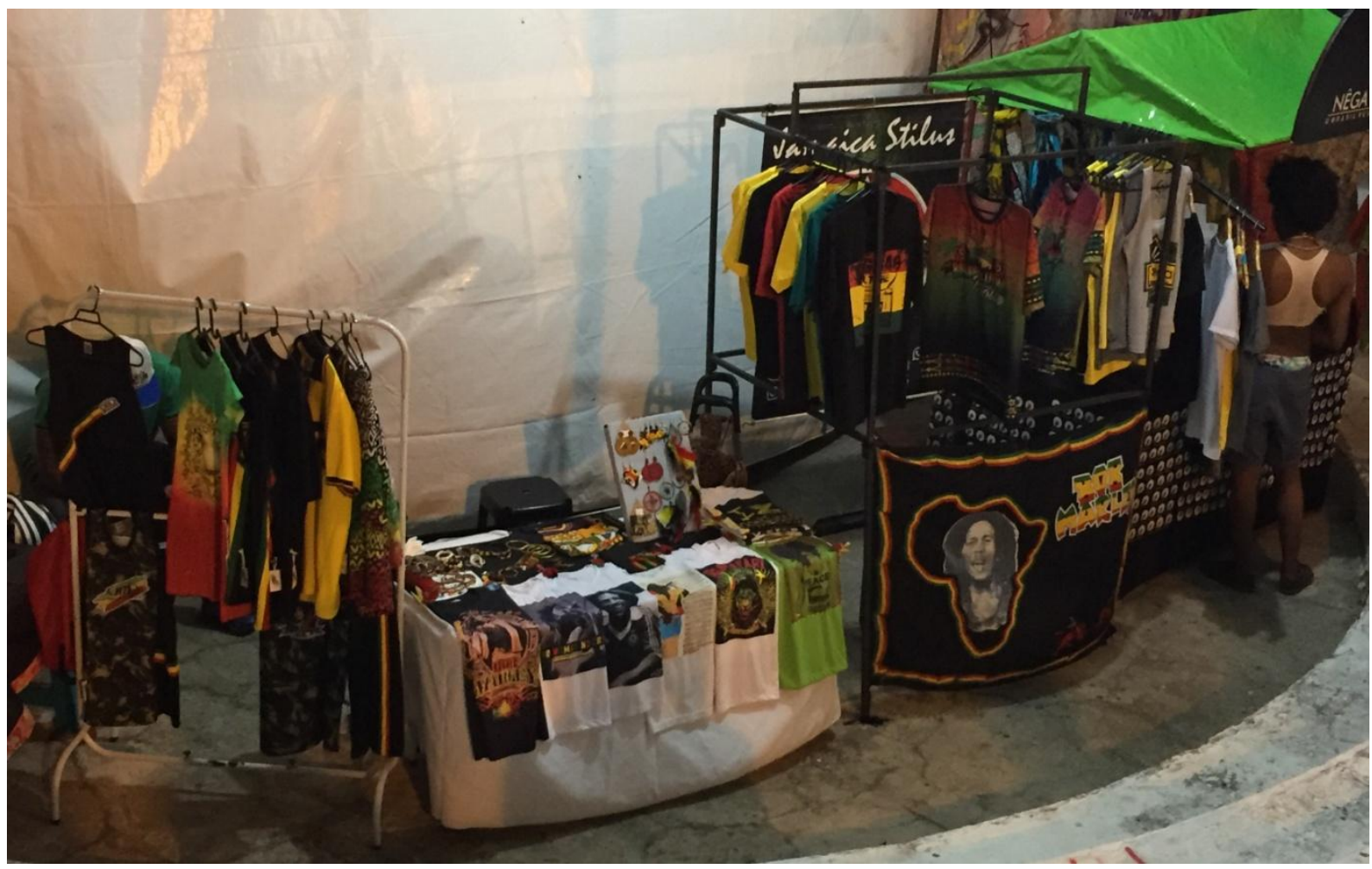




\section{Feira da Praia Grande}

Fim de tarde, quinta-feira, novembro de 2017.

Esse espaço é dedicado ao comércio desde os primórdios da cidade, tendo essa função se mantido apesar das muitas reformas e transformações realizadas ao longo de séculos. A parte de dentro da feira é disposta na forma de corredores circulares e concêntricos, sendo o espaço dividido entre estandes de vendas e lojas com um interior mais amplo. A maior parte do comércio é de alimentos, bebidas e artesanato, com destaque para os produtos regionais. Vendem-se frutas, salgados, doces, café, camarão seco, camarão fresco, castanhas, aguardentes, e nas lojas de artesanato há canecas, placas, cinzeiros (com padrões azulejados), esculturas, redes, roupas, bolsas de fibra de buriti. Os bares ou estandes que vendem bebidas alcoólicas tocam brega e reggae, e talvez sejam os únicos lugares do bairro inteiro em que o público mais numeroso gira em torno dos cinquenta e sessenta anos. Em volta de uma mesinha de plástico, em uma das quatro entradas da feira, cerca de dez senhores idosos jogam/assistem uma partida de dominó.

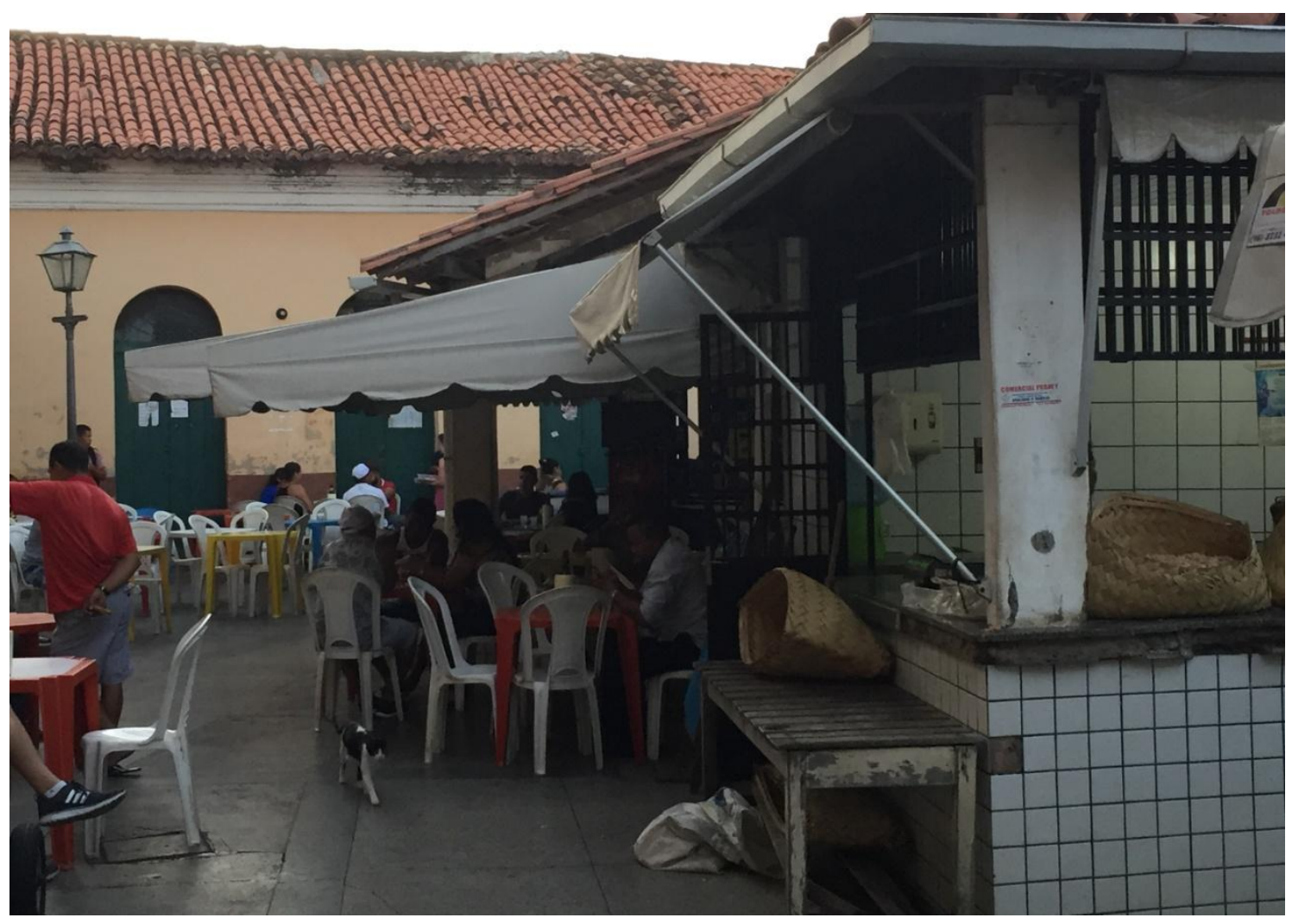

Pessoas bebendo na Feira da Praia Grande no fim da tarde de quinta 


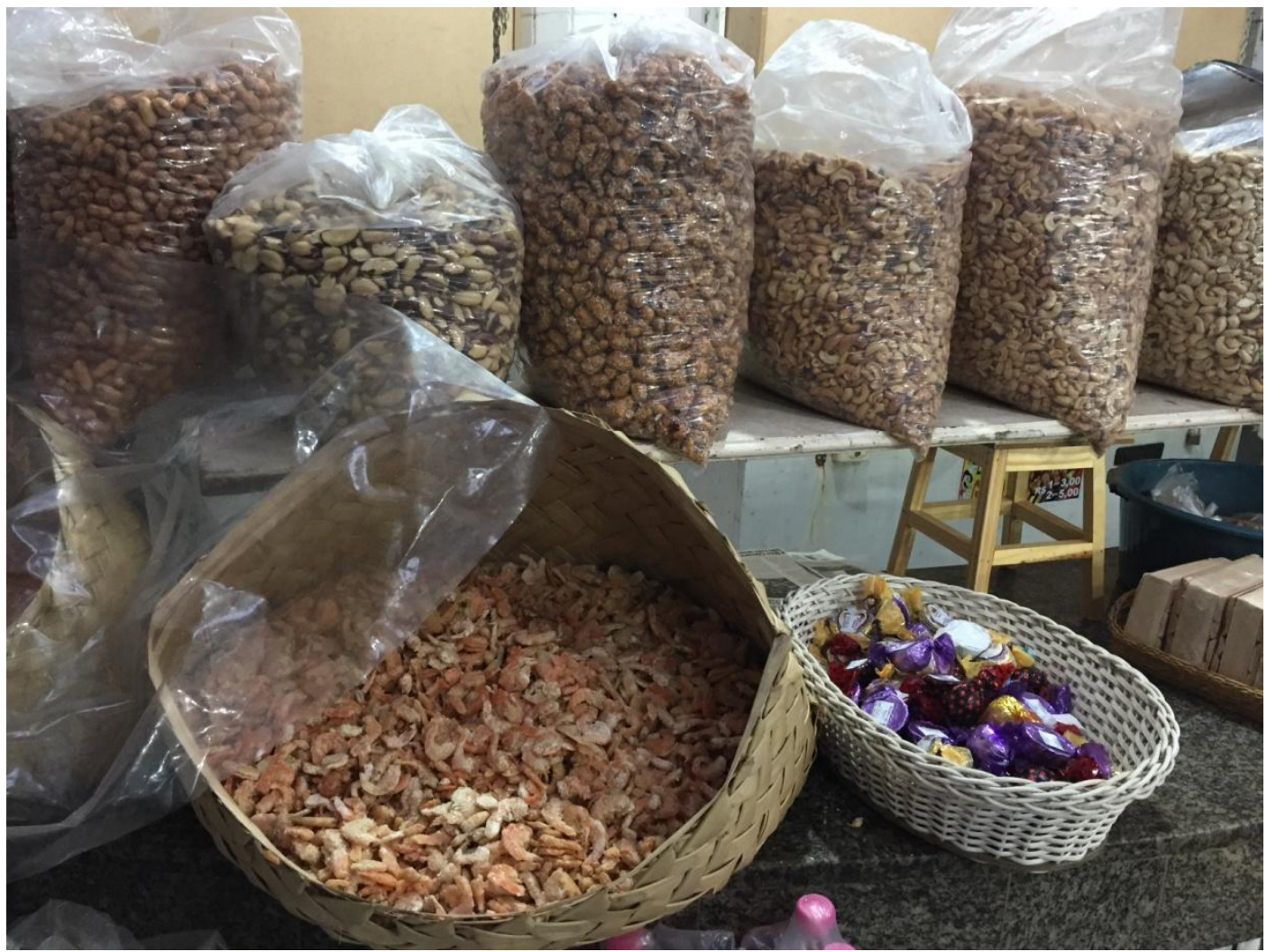

Castanhas e camarão seco

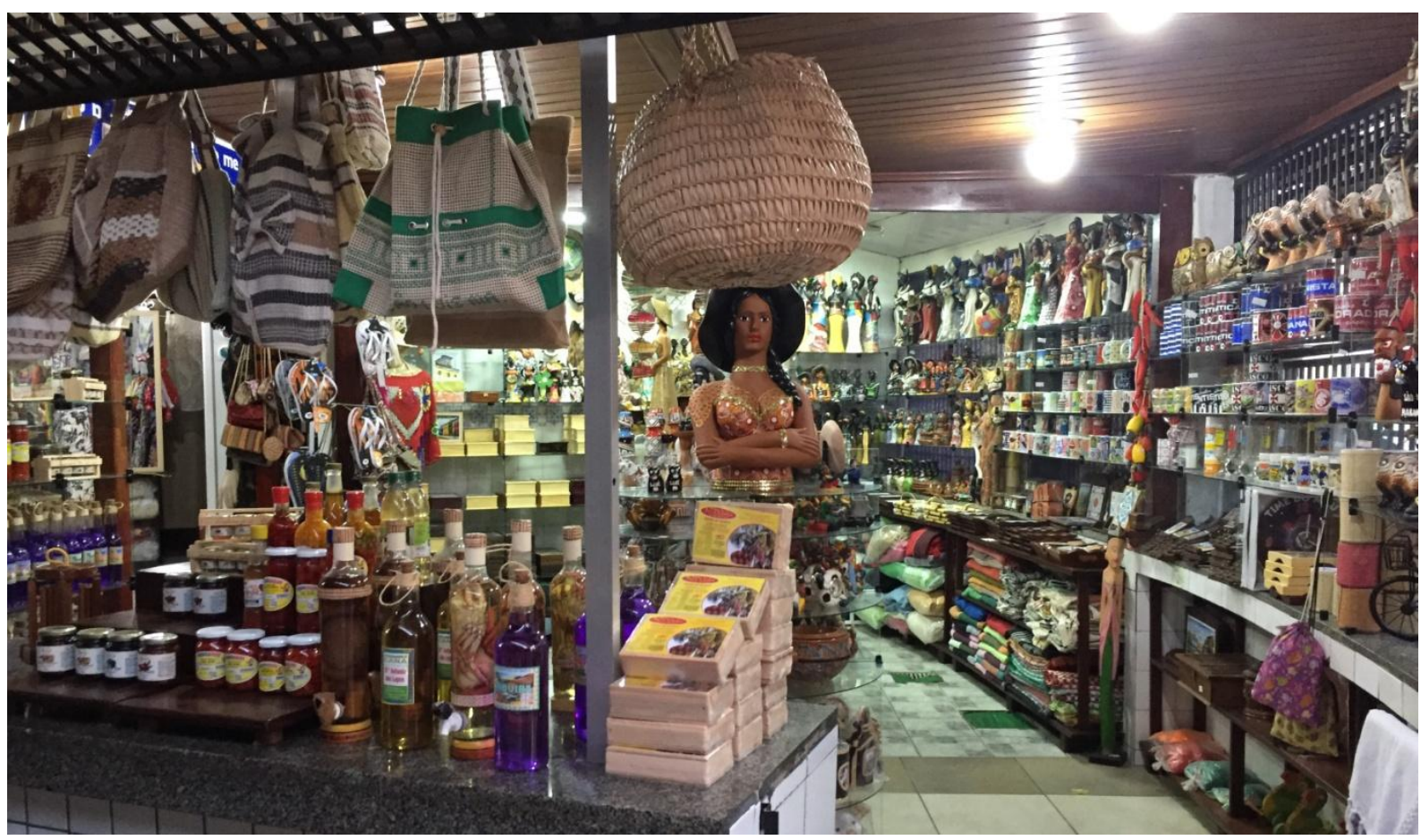

Aguardentes, doces de fruta e artesanato 


\section{Largo do Comércio}

Fim de tarde, quinta-feira, novembro de 2017.

Próximo a uma das entradas da feira, entro em duas lojas de artesanato. Na primeira uma senhora me recepciona. Digo que estou fazendo uma pesquisa sobre os efeitos do turismo no centro histórico e pergunto se ela aceitaria me conceder uma entrevista. Ela responde de forma direta: "Não, porque aqui não tem turista não. Se tiver, não sei onde estão.” Pergunto se então quem compra mais são as pessoas da própria cidade, e ela diz que sim. Pergunto qual produto costuma sair mais. "É roupa."

A senhora que me atende na segunda loja é mais receptiva, além ter percepções distintas. Pergunto quem compra mais naquela loja, se pessoas da cidade ou turistas. “Depende, gente daqui e turista. Mas acho que é mais gente de fora." Pergunto se a variação é pela época e ela diz que sim. Pergunto qual produto mais sai. "Ah, um pouco de tudo."

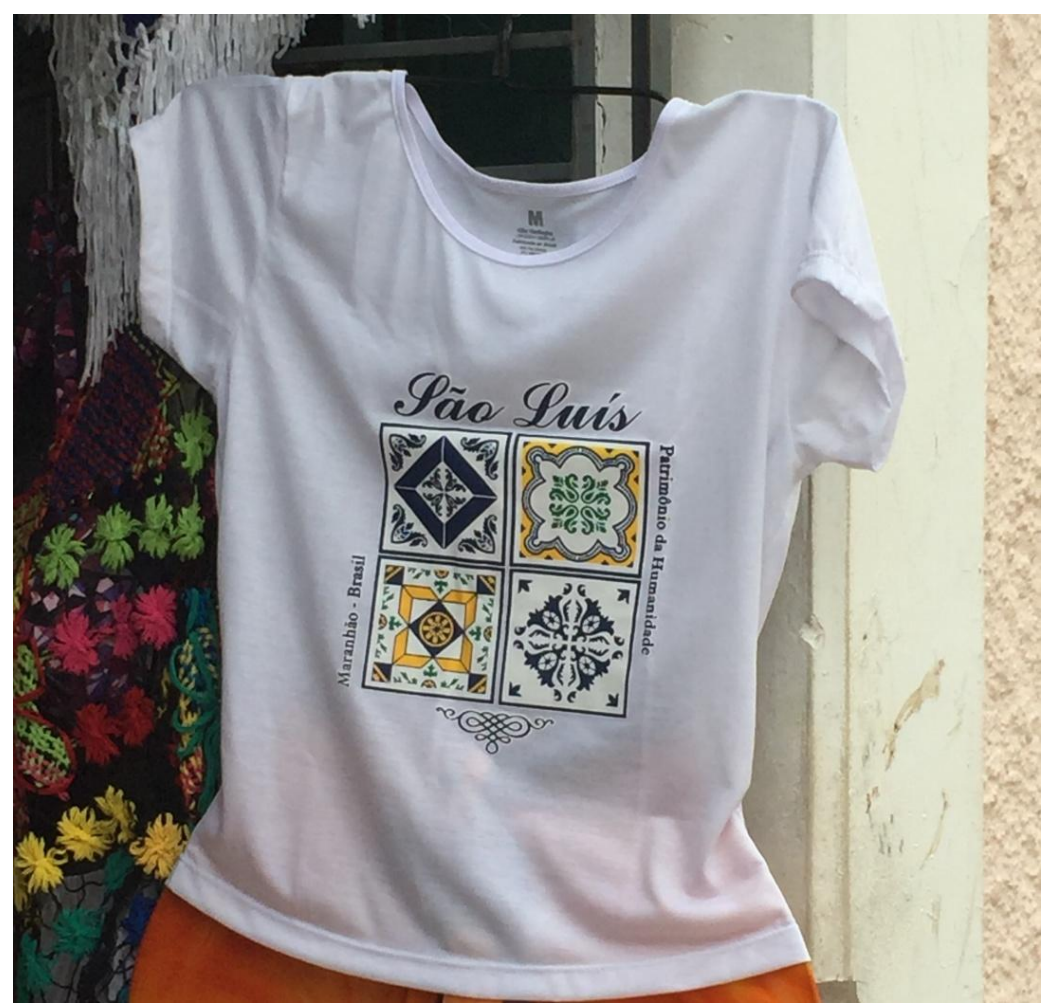

Azulejos portugueses na invenção da cidade Patrimônio 


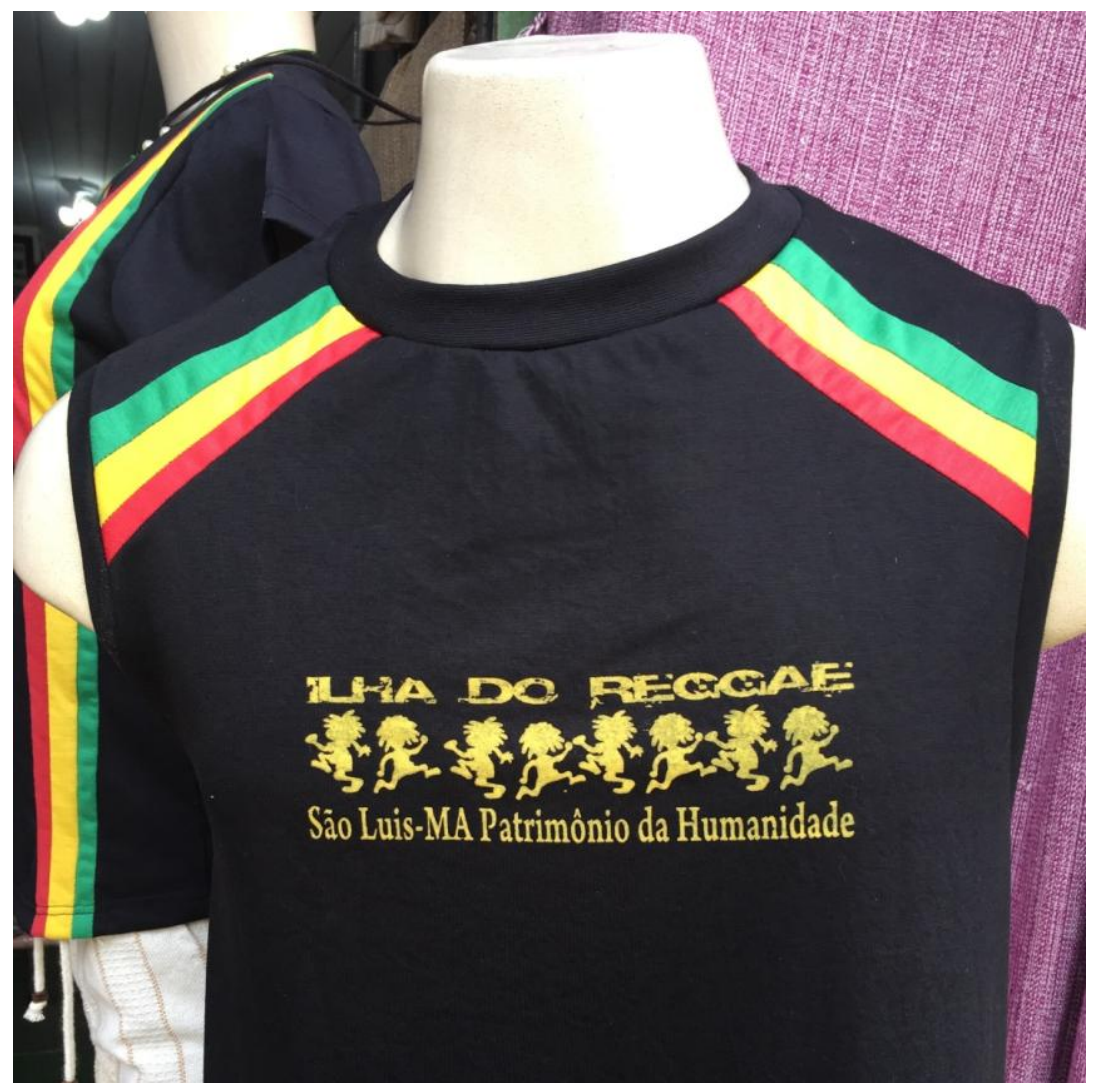

Música caribenha na invenção da cidade Patrimônio

Em frente a essas lojas, fica um pintor de rua ao lado de um grupo de vendedores ambulantes. Ali, ele se mantém fazendo suas telas ao longo dos dias, em um posto visível a todos os passantes. Todas as vezes que passei por ele, em dias diferentes, estava pintando ruas e paisagens do centro. Pergunto a ele se retrata apenas paisagens de São Luís. "Não, faço de tudo, e aceito encomenda." "Tem mais comprador de São Luís ou de fora?" "Os dois. Mas mando até pra São Paulo." Pergunto se ele vende diretamente aos clientes ou se há algum intermediário, e ele responde que "na maioria das vezes é direto, mas às vezes vendo pra loja também". Ele aponta para a fachada de uma loja do outro lado da rua, onde várias pinturas estão expostas. "Ali tem tela minha." 


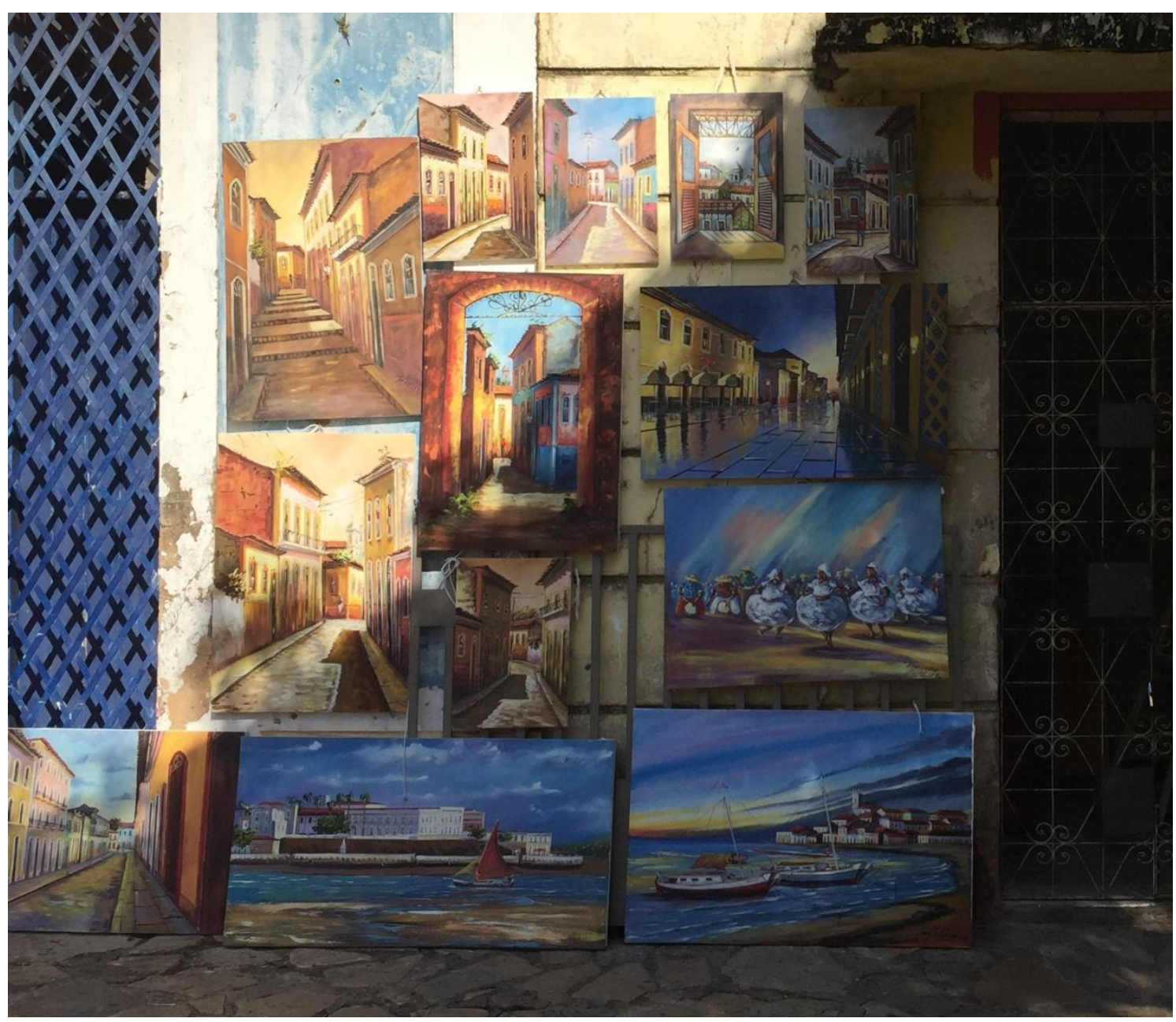




\title{
Capítulo II
}

\author{
O problema:
}

\section{a invenção do centro histórico de São Luís e seus sentidos}

\author{
Só tijuco e água salgada \\ só bagres e baiacus \\ areia sol vento e chuva \\ e as velas coloridas \\ dos barcos pela baía:
}

que perguntava eu ali

com aquele cofo nas mãos

sob o sol do Maranhão?

Ferreira Gullar, Poema Sujo

\section{Tradições inventadas}

Referência cultural incontornável para grande parte dos ludovicenses (cf. foto abaixo), o centro histórico de São Luís ${ }^{22}$, enquanto recorte espacial e paisagem urbana portadora de um valor de excepcionalidade, nem sempre existiu. Sua invenção se deu ao longo do século XX, cerca de trezentos anos depois de erguidas as primeiras edificações onde mais tarde seria a capital maranhense. Essa invenção foi tecida por discursos, classificações e nomeações, mas também é prenhe de sentidos não-verbais: são imagens, condutas, práticas, modos padronizados de agir e pensar que contribuem para fazer, da paisagem da cidade antiga, um "centro histórico". Quais determinantes sociais estão na gênese dessa consagração? Como se

\footnotetext{
${ }^{22}$ Segundo o site do IPHAN (Instituto do Patrimônio Histórico e Artístico Nacional), o centro histórico da cidade de São Luís é composto por cerca de quatro mil edificações exemplares da arquitetura civil colonial portuguesa, em sua maioria dos séculos XVIII e XIX. (Disponível em: http://portal.iphan.gov.br/pagina/detalhes/34 . Acesso em 13/04/2017.) Em 1997, a Organização das Nações Unidas para a Educação, a Ciência e a Cultura (UNESCO) o inscreveu em sua lista do Patrimônio Mundial, sob a justificativa de que "o Centro histórico de São Luís do Maranhão é um exemplo excepcional de cidade colonial portuguesa, adaptada com sucesso às condições climáticas da América do Sul equatorial e tendo preservado em medida notável seu tecido urbano harmoniosamente integrado a seu ambiente natural". (Traduzido da versão em francês do site do Centro do Patrimônio Mundial da UNESCO. Disponível em http://whc.unesco.org/fr/decisions/?id_decision=2869\&. Acesso em 15/04/2017.)
} 
deu o processo de invenção do centro histórico de São Luís, e quais são seus efeitos e durações? Quais são seus agentes principais? E, não menos importante, que outras camadas de significado, plurais e menos óbvias, coexistem com as narrativas dominantes sobre o centro histórico? São essas questões que esta monografia busca responder.

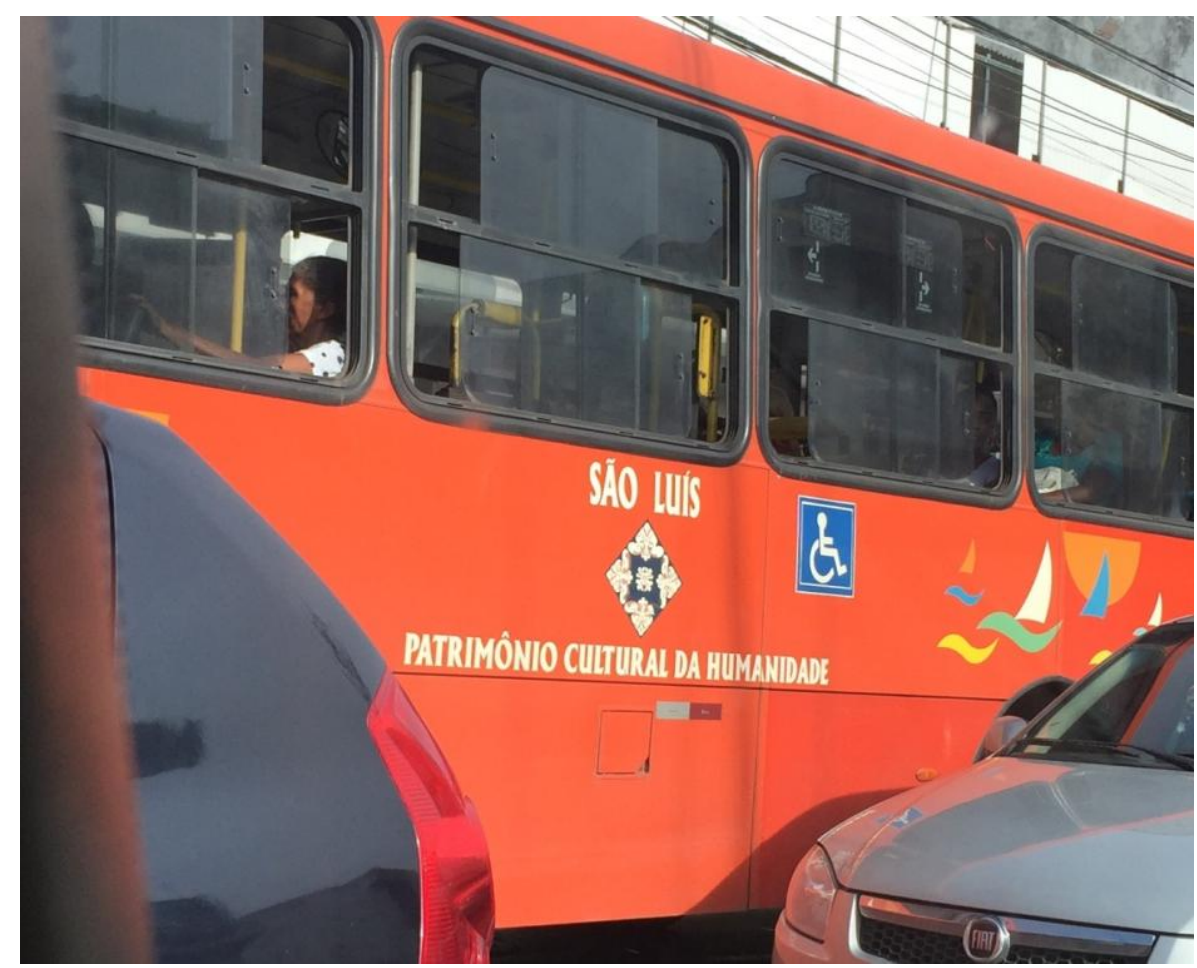

Patrimônio cultural da Humanidade: a consagração inscrita no cotidiano

Para dar conta desse caráter "inventado" do centro histórico, recorri à discussão conduzida por Eric Hobsbawm e Terence Ranger a respeito da invenção de tradições. Segundo Hobsbawm (1983, p. 1),

\begin{abstract}
'tradição inventada' significa um conjunto de práticas, normalmente governadas por regras aberta ou tacitamente aceitas e que são de uma natureza ritual ou simbólica, que buscam inculcar certos valores e normas de comportamento pela repetição, o que automaticamente implica em continuidade com o passado. ${ }^{23}$
\end{abstract}

Assim, essas tradições buscam estabelecer continuidade com um passado específico por meio do simbolismo. Como exemplo, o autor aponta a escolha do estilo gótico para a reconstrução, feita no século XIX, do prédio do parlamento britânico; e também, a escolha "igualmente deliberada" de reconstruir a câmara parlamentar com a mesma exata planta após

\footnotetext{
${ }^{23}$ Todas as citações dessa obra são traduções livres de Hobsbawm e Ranger (1983).
} 
a $2^{a}$ Guerra Mundial. Veremos que, também no caso de São Luís, uma reconstrução se presta à criação de um efeito de continuidade temporal: em 1988, o governador do estado do Maranhão veio a decretar "a reconstrução e revitalização do acervo do Centro Histórico de São Luís de modo a dar a essa área, dentro do possível, a feição arquitetônica que ali predominava nos séculos passados" (CAFETEIRA, 1993, p. 126). ${ }^{24}$

O aspecto da formulação de Hobsbawm que é central para a construção do problema desta pesquisa, nesse sentido, é precisamente o seguinte: o efeito de continuidade histórica que a invenção de tradições engendra, de modo a permitir que criações recentes apareçam na memória e no imaginário coletivos como portadoras de uma antiguidade fundada em tempos imemoriais. Creio que é o caso da região central da cidade de São Luís, Maranhão, que em seus primeiros séculos coincide com os próprios limites da cidade ${ }^{25}$, para ao longo do século XX ser destacada do resto do município e passar ser reconhecida como um "centro

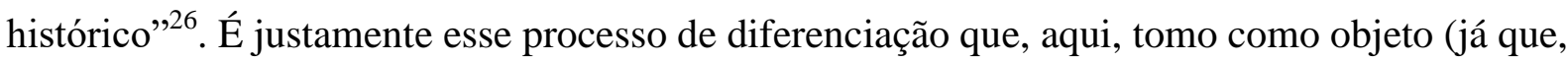
antes da gênese dessa diferença, não havia nada de "histórico" na paisagem composta por aquelas ruas e edificações, sendo elas tão somente o cenário da vida cotidiana). O problema, então, torna-se o de compreender ${ }^{27}$ como se inventa essa excepcionalidade, e quais são suas condições sócio-históricas de possibilidade.

\footnotetext{
${ }^{24}$ A relação entre centro histórico e tradição é observada, por exemplo, na tese de Albernaz (2004, p. 29): "Passei a perceber que, quando me falavam da cidade, seus moradores, com relativa independência da posição que ocupam na estrutura social - renda, raça, sexo, gênero, escolaridade - partilhavam opiniões semelhantes sobre as características que a definiriam. Uma delas era a relação com o tempo, sendo enfatizado que a cidade e seus moradores atuam no momento presente num diálogo com o tempo passado, expresso no termo tradição. Uma frase freqüente era: São Luís sabe manter a tradição. Um exemplo recorrente: a arquitetura colonial do centro da cidade $[\ldots]$ "..

25 “Até a década de 1940, a área constituída pelo traçado urbano original da cidade configurava o principal núcleo urbano da Ilha" (NORONHA, 2015, p. 104).

26 "Mais interessante, do nosso ponto de vista, é o uso de materiais antigos para construir tradições inventadas de um tipo novo, com propósitos bastante novos" (HOBSBAWM, 1983, p. 6).

27 "Sociologia (no sentido aqui entendido desta palavra empregada com tantos significados diversos) significa: uma ciência que pretende compreender interpretativamente a ação social [...]" (WEBER, 2012, p. 3).
} 


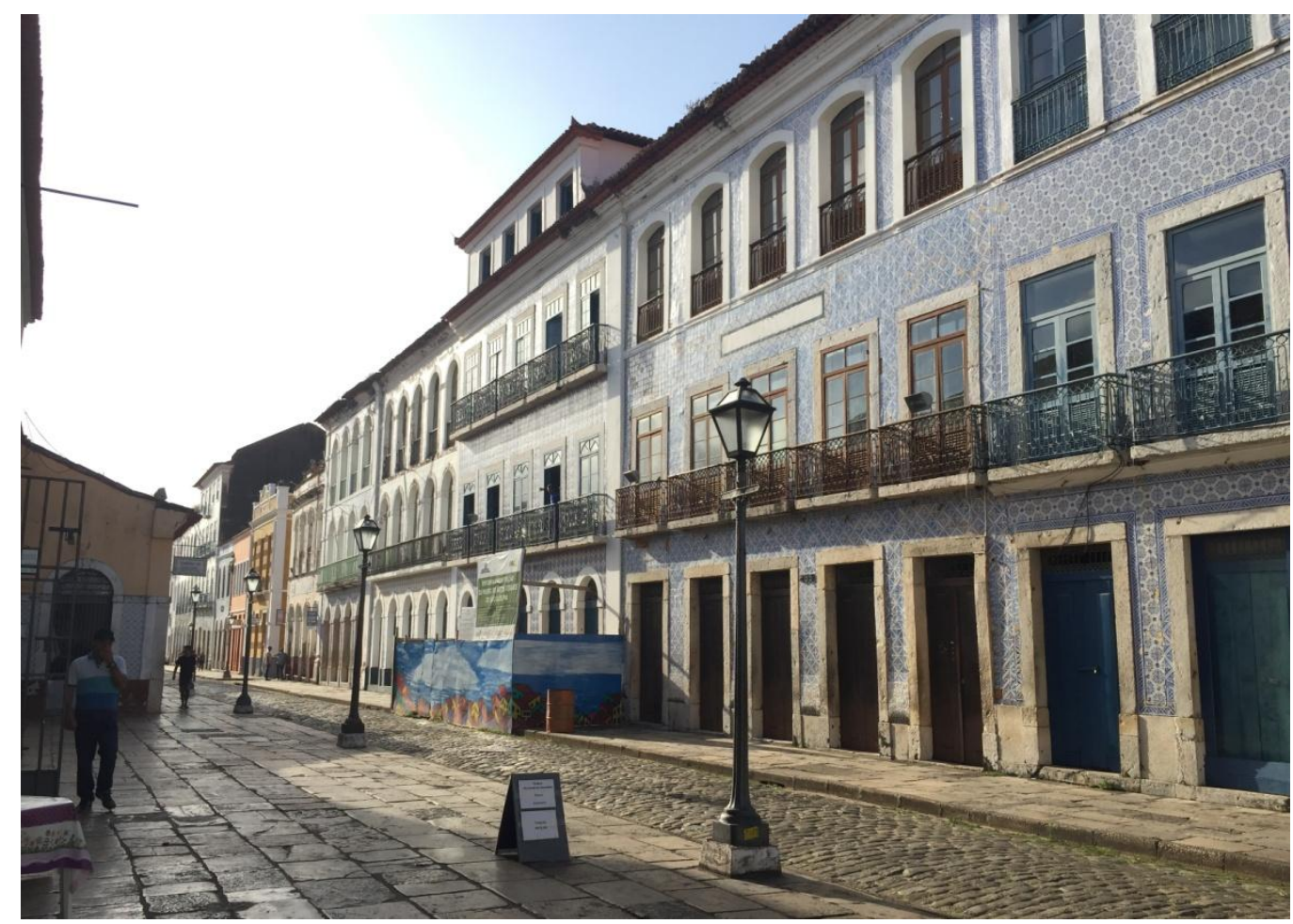

Duas ruas cartão-postal: Rua Portugal (acima) e Rua do Giz (abaixo)






\section{Lugar de memória, processualidade de longa duração e figuração}

Podemos compreender que o ser social é aquilo que foi; mas também que aquilo que uma vez foi ficou para sempre inscrito não só na história, o que é óbvio, mas também no ser social, nas coisas e nos corpos.

Pierre Bourdieu, Le mort saisit Le vif: As relações entre a história reificada e a história incorporada

Ao mesmo passo em se explicita o objeto da monografia, cumpre também esclarecer algumas das concepções teóricas que informam a presente problematização. Nesta seção, especificamente, tratarei do conceito de lugar de memória e da perspectiva figurativoprocessual de longa duração, que compõem o esquema através do qual abordarei esse objeto. Enquanto o primeiro conceito é elaborado por uma vertente da historiografia francesa, e operacionalizado por uma etnografia histórica do antropólogo estadunidense Richard R. Flores, o ponto de vista figurativo-processual se constitui com recurso principalmente à sociologia de Norbert Elias.

O trabalho de Flores (2002), intitulado Remembering the Alamo: Memory, Modernity and the Master Symbol, é inspirador na medida em que apresenta uma análise da construção simbólica de um lugar de memória, pelo prisma das relações entre memória e modernidade (FLORES, 2002, p. XV). O lugar em questão é o Alamo, as ruínas de uma fortaleza em San Antonio, no estado norte-americano do Texas, que foi palco de uma batalha, em 1836, entre "anglos" - os colonos texanos de língua inglesa - e mexicanos, no contexto da separação do Texas em relação ao México, cerca de uma década antes da anexação daquela região aos Estados Unidos. Nessa batalha, ganha pelos mexicanos, cerca de 150 anglos foram mortos, incluindo os líderes das forças "proto-estadunidenses". Décadas depois, como aponta o autor, o lugar passou a ser tomado como um símbolo, figurando "grandemente na imaginação local e nacional" (FLORES, 2002, p. IX) ${ }^{28}$.

No entanto, ele faz a ressalva de que

a história de como o Alamo emergiu como um sítio importante da memória cultural estadunidense não começa em 1836, mas na última parte do século XIX enquanto o Texas passava por uma vasta transformação social (FLORES, 2002, p. 1).

\footnotetext{
${ }^{28}$ Todas as citações dessa obra são traduções livres de Flores (2002).
} 
Nesse sentido, o problema posto pelo autor passa a ser não a história do lugar em si, mas "uma exploração de como o Alamo é relembrado através de vários gêneros de cultura pública e popular e como essas lembranças estão enredadas com discursos históricos oficiais sobre os eventos de 1836". Isto, levantando a questão da seletividade da memória (a que voltarei mais adiante):

o processo de 'lembrar' requer [...] um certo nível de 'esquecer'. Mas esquecer não é uma experiência passiva; como lembrar, é um processo ativo que envolve apagamento. A memória, em ser seletiva, ativamente esquece ou 'silencia o passado' (FLORES, 2002, p. XV).

Assim, com o objetivo de pensar justamente esse enredamento de narrativas, o antropólogo introduz uma ideia que aqui interessa reter: a de construção pública do passado. No escopo de uma outra preocupação analítica de sua obra, a saber, a formação das identidades étnico-raciais de "anglo" e "mexicano" a partir do simbolismo Batalha do Alamo, Flores demonstra como um filme que conta a história da batalha de 1836, exibido na fortaleza refuncionalizada enquanto aparelho cultural, é uma narrativa marcada por lembranças e esquecimentos, que se estrutura por meio de pares de opostos como "nós" (anglo-texanos) e “eles" (mexicanos), vencedores e perdedores, liberdade e tirania. Com efeito, o Alamo se configura como "uma apresentação que inerentemente limita o espectro de significados, fixando a memória (não a história) ao lugar. Mas qual é a história da memória-fixada-aolugar?" Ao responder a essa indagação, a partir da "apresentação pública" da história da batalha de 1836, o autor conclui: "Essa história, da memória-fixada-ao-lugar, é uma história de poder" (FLORES, 2002, p. 32).

Por essa perspectiva, a do poder que engendra a fixação da memória social aos lugares, a proposta deste trabalho dialoga com a etnografia de Flores. Em um dos capítulos de seu livro, o autor descreve o processo de construção do Alamo, que ele aponta ser o lugar mais visitado do estado do Texas. Processos como esse, indica Flores (2002, p. 61), “transformam visões privadas em lugares públicos". Nesse escopo, é exposto que a forma e os sentidos que o lugar veio a ter na contemporaneidade se devem, significativamente, a um movimento preservacionista que se desenrolou apenas nos primeiros anos do século $\mathrm{XX}$, liderado por uma organização tradicionalista intitulada Daughters of the Republic of Texas. Antes da compra do espaço por parte dessa organização, em 1905, ele havia chegado a servir de depósito, loja de suprimentos e saloon. Assim, analisando alguns escritos das duas principais expoentes da compra e dos esforços de preservação do Alamo, Flores desvela 
algumas motivações e valores que ajudaram a conformar a narrativa que hoje se apresenta no e sobre o lugar. Essa narrativa segue uma "poética da sentimentalidade e da restauração" (envolvendo lendas e heróis), em um ambiente social marcado pela modernização e pela expansão capitalista - processo que contribui para erodir o modo de vida tradicional do Texas (FLORES, 2002, p. 81). Dessa forma, o autor oferece uma perspectiva analítica sobre uma dinâmica social de construção pública do passado, em correlação com a materialidade do lugar; perspectiva essa que aqui serve como modelo e inspiração.

Uma das ferramentas teóricas utilizadas por Flores no momento de delimitar seu objeto de análise, e que também busco retomar, é o conceito de "lugar de memória", elaborado principalmente pelo historiador francês Pierre Nora. Cumprindo aqui uma função de síntese, esse conceito se refere precisamente a esses lugares, concretos e físicos, nos quais narrativas da memória social vieram a se fixar, tomando-os como evidência que as valida. $\mathrm{Na}$ teorização de Nora, esse tema é indissociável de uma reflexão sobre a questão da modernidade, na medida em que a "aceleração" moderna da história condena as sociedades ao esquecimento. Segundo o autor, "[h]á locais de memória porque não há mais meios de memória" (NORA, 1993, p. 7). Com isso, ele quer remeter especialmente ao desaparecimento das mnemotécnicas de grupos humanos assentados sobre as bases da memória oral, como por exemplo os camponeses, uma "coletividade-memória". Na visão de Nora, com a aceleração trazida pela vida moderna, a consciência histórica passou a absorver a memória (NORA, 1993, p. 9). Segundo o autor,

[o]s lugares de memória nascem e vivem do sentimento que não há memória espontânea, que é preciso criar arquivos, que é preciso manter aniversários, organizar celebrações, pronunciar elogios fúnebres, notariar atas, porque essas operações não são naturais. [...] Sem vigilância comemorativa, a história depressa os varreria. São bastiões sobre os quais se escora. Mas se o que eles defendem não estivesse ameaçado, não se teria, tampouco, a necessidade de construí-los. Se vivêssemos verdadeiramente as lembrança que eles envolvem, eles seriam inúteis. [...] É este vai-e-vem que os constitui: momentos de história arrancados do movimento da história, mas que lhe são devolvidos (NORA, 1993, p. 13).

De modo que, para Nora (1993, p. 22), “a razão de ser de um lugar de memória é parar o tempo, é bloquear o trabalho do esquecimento". 
Ademais, à ideia de lugar de memória, se somam ainda duas premissas teóricometodológicas, retiradas da proposta de sociologia de Norbert Elias: a concepção de que as interdependências humanas são constituídas por nexos de conhecimento intergeracionalmente transmitido, e a perspectiva temporal que aborda essas interdependências no interior de processos sociais de longo prazo. As duas premissas são parte de uma tomada de posição, por parte do sociólogo alemão, contrária à tradição filosófica que descreve o conhecimento humano como atributo individual e independente das circunstâncias sociais e históricas (do inatismo de Descartes ao sujeito transcendental de Kant).

A tradição filosófica partiu da suposição de que a aquisição de conhecimento para cada ser humano é universalmente a mesma. [...] Segundo esse prisma, não se pode dar conta do fato de que o conhecimento humano é transmitido de geração em geração, em outras palavras, de que cada ser humano adquire conhecimento de outro ser humano por meio do aprendizado. Nem tampouco dar conta do fato de que o conhecimento, individualmente, bem como ao longo de gerações, pode crescer ou declinar. (ELIAS, 1998, p. 26-27)

Nesse sentido, o que há, no lugar de indivíduos autossuficientes, é um encadeamento de conhecimentos construídos socialmente ao longo de gerações; e é esse encadeamento histórico que produz as permanências e as mudanças nos padrões de comportamento dos seres humanos (tal como mostrado pelo autor em sua obra mais famosa, O Processo Civilizador). Segundo Elias (1994, p. 96),

[n]o caso dos seres humanos, e neste caso apenas, a transmissão do conhecimento através de símbolos sociais permite às gerações posteriores basearem-se no conhecimento das gerações anteriores e submetê-lo a revisões a alargamentos.

Esse fundo social de conhecimento - que tem na linguagem ${ }^{29}$ uma de suas principais expressões - informa os modos institucionalizados de ser, agir e pensar, carregando em si um conjunto de mediações históricas. Por isso, a compreensão sociológica passa, inevitavelmente,

\footnotetext{
29 "A aquisição de uma língua dá, de facto, a um ser humano individual o acesso a um fundo social de conhecimento que, meramente em termos de dimensão, é um múltiplo do que uma pessoa pode aprender sozinha com a experiência pessoal não verbal. O fundo de uma língua contém, de facto, o sedimento das experiências realizadas no decurso de muitas gerações por muitos indivíduos diferentes e aí depositadas sob uma forma simbólica. Ele não só empresta uma coloração a todas as experiências realizadas pelos próprios indivíduos, mas também, lhes permite reutilizar as experiências e as reflexões dos outros. Em suma, o conhecimento por meio do qual as pessoas agem sofre uma expansão explosiva se, através da aquisição de uma língua, elas estabelecerem uma ligação com o fundo de conhecimento de uma sociedade" (ELIAS, 1994, p. 92).
} 
por identificar essas mediações, isto é, os processos sociais que contribuíram para estabelecer, através de nexos simbólicos, as interdependências humanas que se quer explicar.

Tais processos, no entanto, devem ser considerados, segundo a proposta de Elias, em uma perspectiva temporal específica: aquela que enfatiza a longa duração das dinâmicas sociais. Essa tarefa o autor define na esteira de uma crítica à sociologia que se limita a processos de curto prazo:

O trabalho de muitos sociólogos está inteiramente concentrado no tempo presente. A esse respeito sua visão assemelha-se àquela da sociedade como um todo. Sua compreensão do fato de o que denominamos tempo presente ter caráter pontual, não passando de um momento de um processo em marcha, parece ter declinado. $\mathrm{O}$ fato de a condição social representar um instante de um processo contínuo que, vindo do passado, se move ao longo do presente para um futuro ainda desconhecido parece dissipar-se. [...] Entretanto, os fatos com que os sociólogos e outros cientistas sociais se preocupam dificilmente podem ser entendidos, e certamente não serão explicados, se a diferença experimentada entre presente e passado não for neles projetada - se os tempos presentes forem percebidos, como têm sido, isoladamente. Assim, a reconstrução, na forma de modelos, dos processos que conduzem do passado, ao longo dos poucos dias daqueles que estão vivos, ao futuro, é tarefa indispensável dos sociólogos. (ELIAS, 1998, p. 24)

O autor lembra que

Hegel, tal como Comte, considerou, de facto, como sujeito do conhecimento uma unidade social, a cadeia de gerações entrelaçadas, apesar de ele a ter personificado como espírito ou Geist. [...] Durante os séculos XIX e XX, os filósofos regressaram largamente, nas suas teorias do conhecimento, à tradição centrada no indivíduo e não processual de Descartes e Kant. A ruptura com esta tradição, tentada por Hegel e Comte, foi vingada por uma feroz estigmatização. Entre os filósofos e, num período em que os cientistas sociais seguiam, nestas matérias, a orientação dos filósofos, também entre os sociólogos, os seus trabalhos foram proscritos e tomados como um objecto de escárnio. [...] As ciências humanas foram sobrecarregadas com uma herança que bloqueia o caminho para uma síntese de nível superior e, deste modo, para modelos teóricos sobre os processos sociais de longo prazo. [...] Não há razão para excluir a possibilidade de estes modelos poderem 
constituir, puramente, instrumentos de investigação científica e instrumentos de uma orientação dos seres humanos, no interior do seu mundo, mais relacionada com os factos. (ELIAS, 1994, p. 122-3)

Essas passagens explicitam algumas premissas com as quais, neste trabalho, recorro ao conceito de lugar de memória para classificar o espaço físico, social e simbólico que tomo como objeto: entendendo, com Elias, que os sentidos desse lugar são resultado de um processo social longo e continuado. Por fim, na contrapartida da noção de processo, está o conceito de figuração. Essa ferramenta conceitual cunhada por Elias servirá para abordar os momentos decisivos do processo intergeracional que é a invenção do centro histórico de São Luís. Para o historiador Roger Chartier (2001, p. 13), uma figuração, tal como definida por Elias,

é uma formação social, cujas dimensões podem ser muito variáveis (os jogadores de um carteado, a sociedade de um café, uma classe escolar, uma aldeia, uma cidade, uma nação), em que os indivíduos estão ligados uns aos outros por um modo específico de dependências recíprocas e cuja reprodução supõe um equilíbrio móvel de tensões.

Dessa forma, a noção de figuração se constitui como instrumento teórico-analítico que permite captar a forma específica que as interdependências humanas assumem em um determinado momento de um processo social. Cada figuração se trata, nesse sentido, de um equilíbrio dinâmico formado por uma rede de posições sociofuncionais, unidas entre si por afinidades e tensões. Esses laços, que podem tomar uma forma diferente a cada instante da dinâmica social que se tem como objeto, se estabelecem entre seres humanos necessariamente inter-relacionados, inviabilizando uma perspectiva analítica que abordasse "indivíduo" e "sociedade" de forma estanque e dicotômica. Antes, o que o conceito de figuração sublinha é o caráter simultâneo desses dois polos, de modo que as mútuas implicações dos seres humanos são o que compõe o próprio tecido da história social. Assim, os movimentos desta última adquirem forma estruturada, na medida em que se torna possível identificar as interdependências específicas que estão em jogo no interior de cada momento histórico. Essas interdependências aparecem então como a unidade analítica prioritária da sociologia, cujo objetivo é o de compreender os processos sociais a partir de suas várias figuras.

Para Roger Chartier (2001, p. 14), 
[e]m cada formação, as interdependências existentes entre os sujeitos ou os grupos se distribuem em séries de antagonismos, instáveis, móveis, equilibrados, que são a própria condição de sua possível reprodução. Segundo Elias, existe aí uma propriedade universal, estrutural, de todas as formações sociais - mesmo que, é claro, o equilíbrio das tensões tenha um desenho totalmente específico em cada uma delas.

Pois, nas palavras de Elias,

[n]o centro das figurações móveis, ou seja, no centro do processo de figuração, se estabelece um equilíbrio flutuante das tensões, um movimento pendular de equilíbrio das forças, que oscila ora para um lado, ora para o outro. Esses equilíbrios de forças flutuantes incluem-se entre as particularidades estruturais de qualquer figuração. (apud CHARTIER, 2001, p. 14)

Assim, cada "figuração móvel" consiste em uma rede estruturada, um arranjo específico entre posições sociofuncionais unidas por trocas simbólicas. Abordando analiticamente as figuras formadas por essas tramas de sentido, se torna possível compreender não somente seu arranjo particular, mas também sua historicidade, isto é, os processos históricos anteriores, de curta ou longa duração, que tornam possível cada equilíbrio dinâmico momentâneo.

O antropólogo Rogério Proença Leite, ao estudar os usos do patrimônio cultural na reinvenção contemporânea do Recife Antigo, cunha uma categoria analítica que aqui pode ser acoplada ao conceito de figuração: ele chama de "fluxo de atribuição de sentidos" cada momento de transformações decisivas na paisagem do bairro (LEITE, 2001, p. 361). Dessa forma, um grande fluxo de atribuição de sentido acontece nos próprios primórdios da cidade, quando ela é planejada estrategicamente de acordo com o projeto colonial expansionista holandês, que ergue muros que funcionam também como fronteiras sociais e simbólicas. Outro fluxo como esse tem lugar quando de uma reforma de inspiração haussmaniana, em 1910, que ocorre de modo a inventar uma imagem moderna para o centro antigo do Recife. Nesse momento, o ideal da cidade "ampla e higiênica" é o que dá as diretrizes da construção do espaço urbano. O terceiro grande fluxo de atribuição de sentido, na descrição do autor, consistiria na intervenção realizada na década de 1990, orientada por um "plano de revitalização" que traz em seu bojo também um processo de "gentrificação". 
De maneira semelhante, também as figurações decisivas do processo de invenção do centro histórico de São Luís podem ser compreendidas enquanto fluxos de atribuição de sentido, isto é, operações de imputação de significado que se estruturam em rede, tal como elaborado pela perspectiva figurativo-processual eliasiana. Tomando cada figuração como uma trama dinâmica e um fluxo semiótico, será possível compreender como se dá essa construção pública do passado (e do presente), através da tessitura de narrativas em torno da forma urbana em questão.

\section{História da cidade como história das guerras de imagens}

No sentido desse objetivo geral, é possível postular, de saída, que a invenção do valor simbólico de uma configuração urbana não se constrói de forma unívoca ou monolítica. Por debaixo de categorias abstratas como, por exemplo, "centro histórico" ou "Patrimônio Mundial" "30, escondem-se uma série de sentidos, discursos, narrativas e simbolizações diferenciadas. Essas narrativas muitas vezes são dissonantes; outras vezes, são solidárias entre si. Antes de mais nada, é de disputas pela imputação de sentido legítimo, com suas contradições e polissemias, que estamos tratando quando pensamos em analisar os significados compartilhados de uma paisagem urbana.

Como ensina Pierre Bourdieu (2001, p, 228), “o mundo social é, ao mesmo tempo, o produto e o móvel de lutas simbólicas, inseparavelmente cognitivas e políticas, pelo conhecimento e pelo reconhecimento". Nesse sentido, o modo como se dá o reconhecimento de uma narrativa específica sobre a cidade, em detrimento de diversas outras possíveis, constitui um aspecto central a ser compreendido. Isto, na medida em que ocorre a ampla circulação e a dispersão dessa narrativa, que se torna um conhecimento transmitido intergeracionalmente ${ }^{31}$ e passa a compor o imaginário público coletivo.

É com vistas a apreender essa dimensão de saber/poder, a do poder simbólico engendrado pelas lutas "inseparavelmente cognitivas e políticas", que utilizo (cf. p. 26) enquanto ferramenta conceitual a noção de política da imagem. Com essa noção, quero

\footnotetext{
${ }^{30} \mathrm{Ou}$, no caso de São Luís, também as alcunhas que visam nomear a cidade a partir de traços idiossincráticos: "Cidade dos Azulejos“, "Atenas brasileira", "Ilha do Amor" e "Jamaica brasileira” são codinomes que possuem cada um sua historicidade, marcada por disputas de sentido.

${ }^{31}$ Em sua Teoria Simbólica, Elias (1994, p. 24) conceitua a transmissão intergeracional dos símbolos de maneira ampla, isto é, "incluindo não só o conhecimento, mas também, por exemplo, os padrões de comportamento e de sentimento".
} 
descrever justamente esses jogos e efeitos de sentido que se desenrolam, implícita ou explicitamente, no tecido das interdependências sociais. Sentidos esses que se materializam tanto nas práticas sociais quanto nas coisas, na historicidade da forma urbana, tanto quanto nas ações simbólicas do presente, e que, quando se tornam parte integrante de uma paisagem ${ }^{32}$ citadina, aparecem como imagem.

Aqui, utilizo a categoria de política da imagem na acepção proposta pelo historiador Serge Gruzinski em seu livro A Guerra das Imagens ${ }^{33}$. Nesse texto, o autor se debruça sobre as imagens e os imaginários correspondentes a partir da análise de um campo empírico específico: o México colonial. Assim, ele passa a observar o modo como, em contextos diversos, aquelas estiveram no centro das disputas que são a um só tempo políticas e culturais. Dando especial destaque ao papel das imagens religiosas barrocas na colonização do México indígena, o autor as situa no interior das guerras culturais que se travam não apenas no contexto colonial em sentido estrito, mas que continuam a ocorrer nas sociedades marcadas por esse tipo de formação. Segundo Gruzinski (2006, p. 15),

[p]or ser a imagem, junto com o texto, um dos instrumentos maiores da cultura europeia, a gigantesca empreitada de ocidentalização que se abateu sobre o continente americano assumiu - ao menos em parte - a forma de uma guerra de imagens que se perpetuou séculos a fio e que nada indica que já esteja encerrada.

É essa compreensão ampla da guerra de imagens que permite ao autor atravessar várias situações em que elas operam como dispositivos decisivos no interior de relações de dominação simbólica. Dessa forma, a análise que enfoca as guerras entre as imagens indígenas e católicas, cujas várias versões se proliferam nas circunstâncias do contato interétnico, se abre, também, para outras maneiras de produção de imaginários: as pinturas religiosas da contrarreforma, passando pela arte dos murais na construção da nação pósrevolucionária mexicana, até a imagem eletrônica da televisão, são tomadas como parte de uma matriz em comum. Em todos esses contextos, elas são o centro de usos políticos dissonantes e até antagônicos; é o caso do culto à Virgem de Guadalupe, que em seus primórdios é objeto de controvérsia interna ao clero católico - sendo inicialmente condenado

\footnotetext{
${ }^{32}$ Segundo Milton Santos (2006, p. 66-69), “[a] paisagem é o conjunto de formas que, num dado momento, exprimem as heranças que representam as sucessivas relações localizadas entre homem e natureza. [...] A paisagem existe através de suas formas, criadas em momentos históricos diferentes, porém coexistindo no momento atual. [...] A paisagem é história congelada, mas participa da história viva".

${ }^{33}$ Devo à comunicação de Alexandre Corrêa (2017) a ideia de aplicar, enquanto chave analítica, os termos de Gruzinski à paisagem urbana do centro de São Luís, tomando-o como imagem.
} 
como "invenção satânica" -, para depois ser incorporado à estratégia da Igreja, que passa a adotar uma política que "se dedica a utilizar ao máximo o instrumento da imagem, tentando mantê-lo sob controle" (GRUZINSKI, 2006, p. 145). É nesse sentido que o autor fixa as políticas da imagem como sua unidade de análise, perspectiva que também buscarei adotar:

Da mesma maneira que a palavra e o texto, a imagem pode, ao seu modo, ser o veículo de todos os poderes e de todas as resistências. O pensamento que ela desenvolve oferece uma matéria específica, tão densa como o texto, mas que costuma ser irredutível a ele, o que não facilita nada a tarefa do historiador obrigado a atribuir palavras ao indizível. No entanto, não são as vias do pensamento figurativo nem, de modo mais clássico, a história da arte e dos estilos, nem mesmo o conteúdo das imagens que aqui nos deterão. E sim o exame dos programas e das políticas da imagem, o desenrolar das intervenções múltiplas que ela acarreta ou antecipa, os papéis que assume numa sociedade multiétnica. (GRUZINSKI, 2006, p. 17-18)

A política das imagens é também uma economia, como Mostra Marie-José Mondzain (2013). Pois a escolha de certas imagens, em detrimento de outras, é uma expressão da economia simbólica inerente a todo processo de produção de sentidos, na medida em que esses sentidos circulam e são valorados desigualmente. Ela se trata, então, de uma modalidade específica de produção de raridades e hierarquias simbólicas e, nesse sentido, de uma economia. Assim, para ajudar a esclarecer essa perspectiva, vale a pena recorrer a mais um caso concreto.

A cidade de São Luís tem sua fundação oficial datada a oito de setembro de 1612, evento que, como o conjunto da colonização do continente americano, está inserido no contexto da expansão mercantilista do comércio transatlântico europeu. No entanto, esse marco inicial foi precedido por diversas outras tentativas de invasão e ocupação europeia do que hoje é o Estado do Maranhão - expedições que visavam explorar a região da foz do rio Amazonas, principal acesso por via aquática aos Andes e seus metais preciosos. Em meados do século XVI, com a divisão da América portuguesa em capitanias hereditárias, o donatário da capitania do Maranhão tentou, sem sucesso, tomar posse de suas terras. Ao longo daquele século, de forma concomitante, corsários franceses já frequentavam a costa daquela porção da colônia portuguesa, e praticavam trocas com os índios tupinambás que a habitavam. $\mathrm{Na}$ esteira desse investimento de exploração, a coroa francesa autorizou, no início do século XVII, uma missão colonizadora liderada pelo fidalgo Daniel de La Touche, que culminou 
com a fundação de um forte - chamado de São Luís em homenagem ao rei Luís XVIII. A localização geográfica, privilegiada do ponto de vista da defesa militar, se situava entre os dois principais rios da ilha que os tupinambás chamavam de Upaon-Açu (Ilha Grande), na entrada da baía que era ponto de convergência das principais vias fluviais que davam acesso ao interior do continente (IPHAN, 2007, p. 21). Essa colônia francesa na América próxima à linha do Equador durou apenas três anos ${ }^{34}$, e ficou conhecida como "França Equinocial", fundada meio século depois da também interrompida tentativa de instalação de uma "França Antártica" onde atualmente é a cidade do Rio de Janeiro.

O local onde se iniciou a ocupação francesa, hoje, é reconhecido como o marco zero da cidade de São Luís, e é onde se situa a Praça Pedro II, que abriga edificações importantes dos poderes civil e religioso, como a Igreja da Sé, o Palácio dos Leões - sede do governo estadual, construído no exato local do forte e ainda conservando suas muralhas -, o Palácio da Justiça e a Prefeitura Municipal. Esta última ocupa um prédio em estilo neoclássico, que tem origens que remontam à antiga Casa de Câmara e Cadeia, cuja construção se iniciou no fim do século XVII. Após sucessivas reformas, o local passou a abrigar o poder público municipal, em uma edificação cujo nome homenageia o chefe da expedição francesa - Palácio de La Ravardière, em referência ao título de nobreza de Daniel de La Touche -, e hoje apresenta, em frente a sua entrada principal, um busto representando esse personagem histórico (foto abaixo). Na placa sob o busto, lê-se: "A Daniel de La Touche, senhor de La Ravardière, homenagem da cidade de São Luís”.

\footnotetext{
${ }^{34}$ A curta duração e a pouca relevância - do ponto de vista da dinâmica de povoamento posterior - dessa experiência, que foi interrompida já em 1615 por tropas portuguesas advindas de Pernambuco, não impediu que, séculos mais tarde, as elites locais maranhenses chamassem atenção ao episódio da fundação francesa, e ao fato de ser São Luís a única capital brasileira fundada por colonizadores daquela origem sociogeográfica. Tal fato, elevado à condição de "mito de origem", não deixou de desempenhar um papel no que poderia ser chamado, nos termos de Bourdieu (2007), de uma estratégia de distinção. Com efeito, como aponta Corrêa (2001, p. 116), "[n]ota-se com facilidade um certo orgulho expresso pelos nativos da ilha em relação ao fato da cidade ter sido 'fundada pelos franceses'. Percebe-se isso nos 'ritos lingüisticos' manifestos na fala de alguns jornalistas locais e nacionais, tanto pelo rádio como pela televisão, agora também via Internet. Ganha espaço nas campanhas publicitárias e de agências turísticas que dão ao fato histórico uma dimensão exagerada."
} 


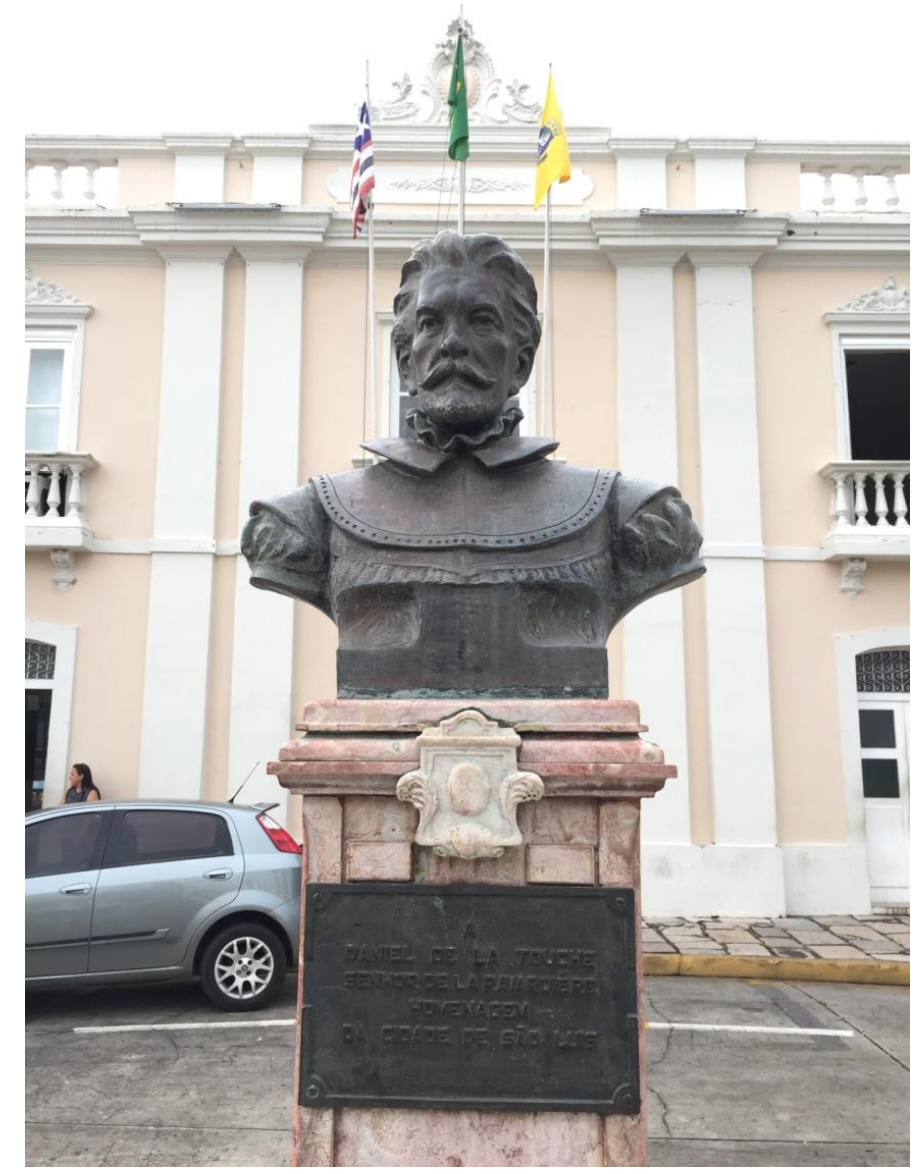

Assim, gravada na própria materialidade da paisagem urbana, encontra-se uma referência comemorativa ao líder da invasão do território tupinambá no começo do século XVII, evento inaugural da história da cidade de São Luís, e que coincide com a inserção da até então Upaon-Açu no mapa da expansão colonial da Europa cristã. Se, por um lado, essa referência pode ser interpretada como uma homenagem de óbvio significado cívico, consolidado pela história oficial que dá conta das origens da cidade, por outro, uma reflexão mais detida pode reposicioná-la no interior de um processo marcado por, justamente, uma política da imagem. Com efeito, esse significado político pode ser observado quando tal referência, materializada em monumento, é comparada a uma outra, mais recente, situada a poucos metros do busto de La Touche. 




Localizada na Praça Marcílio Ramos, na ladeira que dá acesso ao elevado onde se encontra a Praça Pedro II, está uma placa (foto acima) que também homenageia um personagem dos primeiros dias da França Equinocial. Inaugurado no fim de 2016, o monumento faz referência ao índio Tibira ${ }^{35}$, morto na boca de um canhão, em 1613, pelos padres capuchinhos que acompanhavam a expedição francesa, pela acusação de adotar práticas homossexuais. Na placa, lê-se "Tibiras do Maranhão, índio mártir gay, 1613 - 2017. $1^{\text {o }}$ caso de homofobia do Brasil". A forma da execução é relatada pelo próprio padre Yves d'Evreux (1874, p. 233), integrante da missão, em seu livro Viagem ao norte do Brasil feita nos anos de 1613 a 1614:

levaram-no para junto da peça montada na muralha do Forte de S. Luiz, junto ao mar, amarraram-no pela cintura à bocca da peça, e o Cardo vermelho lançou fogo à escorva, em presença de todos os Principaes, dos selvagens e dos francezes, e immediatamente a bala dividio o corpo em duas porções, cahindo uma ao pé da muralha, e outra no mar, onde nunca mais foi encontrada.

\footnotetext{
${ }^{35}$ Segundo o antropólogo Estevão Rafael Fernandes (2014, p. 27), “os Tupinambá chamariam de tibira aos homens e de çacoaimbeguira às mulheres que fossem o que se chamaria hoje de "homossexuais".
} 
Apesar dos diversos impasses e problemas que podem surgir do ato (etnocêntrico?) de nomear, retrospectivamente, um ameríndio do começo do século XVII como gay (uma categoria identitária contemporânea), e o crime ${ }^{36}$ que o vitimou como homofobia (também uma concepção surgida no século XX), a homenagem exemplifica o modo como imagens diferentes, e mesmo contraditórias entre si, podem compor uma paisagem urbana e alterar seus significados. Dessa forma, tanto o busto de La Touche quanto a placa de Tibira são evocações distintas do contato colonial, que ilustram os processos sociais e a lutas simbólicas que pretendo abarcar com o conceito de política da imagem.

$* * *$

A seguir, tento responder ao problema levantado nos parágrafos anteriores, procedendo à análise do processo de invenção tal como definido acima. No entanto, na impossibilidade de apreendê-lo em todas suas nuances e determinações, optei por construir duas figurações heurísticas, correspondentes aos "momentos decisivos" desse processo social. Cada uma dessas figurações constitui uma trama de sentidos específica; sentidos esses que são também contextuais e polivalentes. Pois se há uma permanência do significante "centro histórico", seus significados variam no tempo e no espaço. Assim, é dessa análise dos sentidos de um lugar de memória que as páginas seguintes se ocupam.

\footnotetext{
${ }^{36}$ Segundo reportagem de André Bernardo (s/d), citando o antropólogo Luiz Mott, a execução "infringia o próprio Direito Canônico da Igreja Católica, que não autorizava missionários a condenarem suspeitos de sodomia à morte", cabendo essa prerrogativa apenas ao tribunal do Santo Ofício.
} 


\title{
Capítulo III
}

\section{Momentos decisivos da invenção do centro histórico}

\section{Preâmbulo: decadência e cultura intelectual na São Luís do Segundo Reinado}

\begin{abstract}
Precisamos restabelecer a verdade. A César o que é de César. Maranhão não é Atenas brasileira, Maranhão não é mais que uma triste província de terceira ordem, sem originalidade, sem caráter nacional, sem literatura, sem ciência de espécie alguma, sem a menor noção de Belas-Artes, e sem comércio ao menos. A opinião pública é lá formada e dirigida por uma meia dúzia de portugueses ignorantes e retirados dos negócios; a sociedade diverte-se a falar mal da vida alheia; o trabalho mais rendoso é o tráfico de escravos, e os tais Atenienses de maior monta na província, os únicos que ela respeita, não passam de alguns tipos pretensiosos, cheios de regras gramaticais e tolice.
\end{abstract}

Aluísio Azevedo, no jornal Folha Nova (Rio de Janeiro, 24/02/1883)

Segundo os historiadores do tema (MEIRELES, 2015; VIVEIROS, 2014), a economia agrícola maranhense passa a adquirir maior volume e atividade a partir da criação, em 1756, da Companhia Geral do Grão-Pará e Maranhão, com atuação decisiva do Marquês de Pombal $^{37}$. Foi essa companhia que realizou as primeiras importações regulares de africanos escravizados - sequestrados principalmente na África ocidental, na região do Golfo da Guiné -, embora já haja registros de relações comerciais desse tipo desde a década de 1660 (MEIRELES, 2015, p. 217). Antes disso, a subsistência da região se apoiava principalmente na escravidão indígena. Com efeito, se em 1751 a capitania possuía apenas cinco engenhos de açúcar (e cerca de duzentas fazendas de gado) (MEIRELES, 2015, p. 255), nas décadas seguintes a produção em regime de plantation, principalmente do algodão, não cessou de crescer: as exportações deste último produto passam de 130 sacas, na primeira leva, em 1760, para cerca de 30.000 sacas em 1800 (VIVEIROS, 2014, p. 75). Celso Furtado, em sua Formação Econômica do Brasil, atribui tal crescimento também aos movimentos do mercado mundial da época:

\footnotetext{
${ }^{37}$ À época da criação da companhia, o governador do Estado do Maranhão e Grão-Pará era Francisco Xavier de Mendonça Furtado, irmão do Marquês de Pombal (VIVEIROS, 2014, p. 68).
} 
Dos três sistemas principais [da economia brasileira no século XVIII], o único que conheceu uma efetiva prosperidade foi o Maranhão. [...] Tão importante quanto a ajuda financeira [do governo português], entretanto, foi a modificação no mercado mundial de produtos tropicais, provocada pela Guerra da Independência dos EUA e logo em seguida pela Revolução Industrial inglesa. Os dirigentes da companhia perceberam desde o início que o algodão era o produto tropical cuja procura estava crescendo com mais intensidade, e que o arroz produzido nas colônias inglesas e principalmente consumido no sul da Europa não sofria restrição de nenhum pacto colonial. Os recursos da companhia foram assim concentrados na produção desses dois artigos. (FURTADO, 2009, p. 153)

É nessa quadra histórica que se instala, no Maranhão, o modelo econômico agroexportador e escravista, baseado em elementos como latifúndio, monocultura, comércio exterior, família patriarcal e trabalho forçado ${ }^{38}$. É também nesse período que começam a ser erguidas as ruas e $\operatorname{sobrados}^{39}$ que no século $\mathrm{XX}$ passariam a ser reconhecidos como portadores de um valor histórico e artístico excepcional, sendo então reinventados enquanto bens culturais. Segundo a historiadora Maria de Lourdes Lauande Lacroix (2012, p. 81),

[o] crescimento no volume dos negócios e o aumento de comerciante compeliram colonos mais abastados a promover benefícios à cidade, refletindo na expansão e embelezamento urbano com o calçamento de ruas e substituição de construções precárias por edifícios de pedra e cal, fruto da ação de comerciantes e senhores de terra e escravos, de grande cabedal. Sobrados em estilo clássico colonial português foram levantados, [...] destinados a comércio e residência [...].

\footnotetext{
${ }^{38}$ Tentei abordar algumas consequências históricas da implantação desse modelo socioeconômico na introdução deste trabalho.

${ }^{39}$ Apesar das edificações datarem desse período, o plano urbanístico segundo o qual elas foram dispostas é tão antigo quanto 1615, quando os portugueses conquistaram o território do Maranhão, então sob controle dos franceses. A malha urbana da cidade foi projetada em formato retangular pelo engenheiro militar português Francisco Frias de Mesquita (ANDRÈS, 2006, p. 14), também responsável pela construção de fortes na Bahia e no Rio de Janeiro. O planejamento nesse formato contraria a tese de Sérgio Buarque, contida em Raízes do Brasil, segundo a qual, nas cidades coloniais portuguesas, "o traçado geométrico jamais pôde alcançar [...] a importância que veio a ter em terras da Coroa de Castela: não raro o desenvolvimento ulterior dos centros urbanos repeliu aqui esse esquema inicial para obedecer antes às sugestões topográficas. [...] A cidade que os portugueses construíram na América não é produto mental, não chega a contradizer o quadro da natureza, e sua silhueta se enlaça na linha da paisagem. Nenhum rigor, nenhum método, nenhuma previdência [...]" (HOLANDA, 1995, p. 109-110).
} 
As primeiras décadas de edificação do casario português em São Luís coincidem, também, com a reconstrução de Lisboa sob o comando do Marquês de Pombal, após o terremoto que destruiu parte importante da cidade em 1755. Iniciando-se na segunda metade do século XVIII, esse processo de desenvolvimento material do Maranhão se intensificaria no século XIX, de modo que "o período entre 1808 e 1856 foi o mais movimentado em termos de importação de azulejos, soleiras, portais de cantaria, e de profissionais especializados em construção civil” (LACROIX, 2012, p. 86).

No entanto, a prosperidade da economia agrária maranhense se revelaria efêmera. De fato, Celso Furtado (2009, p. 155) a reputa como sendo parte de um momento de "falsa euforia": segundo o autor, "essa prosperidade era precária, fundando-se nas condições de anormalidade que prevaleciam no mercado mundial de produtos tropicais". Dessa forma, após o período de apogeu mencionado acima, inicia-se uma longa fase de declínio, que tem como correlato, no plano da produção simbólica, o motivo que Alfredo Wagner de Almeida chama de uma "ideologia da decadência".

Segundo Almeida (2008, p. 19), essa ideologia consiste em um conjunto de "formas de explicação da situação econômica e social da região, que se cristalizaram na vida intelectual”. Nesse sentido, a ideia de uma "decadência da lavoura" compareceu com frequência na imprensa, em documentos e discursos dedicados à compreensão da realidade maranhense, no transcorrer do século XIX. Constituindo-se como lugar comum, o esquema explicativo baseado em uma percepção de declínio socioeconômico, que se sucederia a uma "idade de ouro" idealizada da agricultura, passou a ser tomado como autoevidente, adquirindo assim permanência. Como mostra o autor, as formulações relativas à decadência "[t]anto são registradas num Relatório apresentado à Assembléia Legislativa em junho de 1844, quanto num outro de 1857 ou ainda num terceiro de 1876, e assim em diante até fins da década de 80", sem grande variação no tom dos documentos (ALMEIDA, 2008, p. 65). Foi em um desses momentos de constatação do "estado decadente da lavoura", acompanhado da contraposição desse estado ao período dito de prosperidade (correspondente à fase de intensa exportação do algodão e do arroz, que convencionalmente tem seu fim fixado em 1820), que os intelectuais locais elaboraram uma de suas criações mais duradouras: o emblema ${ }^{40}$ da Atenas Brasileira, que veio a marcar várias gerações de produtores culturais maranhenses.

\footnotetext{
40 “Octavio Ianni, em seus estudos sobre a globalização, utiliza uma expressão sugestiva ao se referir à tradição sociológica do século XIX: ele denomina 'emblemas' algumas das problemáticas levantadas pelos pensadores da época. Esse seria o caso dos conceitos de nação, indivíduo, modernidade, multidão. De alguma maneira,
} 
O historiador José Henrique Borralho descreve esse emblema como resultado de uma modalidade particular de participação, por parte das elites letradas do Maranhão, no jogo de formação da identidade nacional brasileira no período imperial. Nesse contexto, ganhou força a ideia de que a província seria uma "Atenas Brasileira", por ser dotada de um panteão de escritores e intelectuais notáveis (cf. p. 34), artífices de grandes realizações culturais e espirituais. Tal elaboração foi uma maneira de marcar posição no concerto das regiões da nação recém-independente, na forma de "um projeto de formação de uma cultura oficial que desse visibilidade ao Maranhão perante as demais províncias” (BORRALHO, 2009). Esse projeto vinha também como resposta à instabilidade provocada pela guerra civil da Balaiada (1838-1841), que começou como um conflito intra-oligárquico entre o governo da província e sua oposição política, e evoluiu para revolta popular e racial, sob a liderança do chefe quilombola Cosme Bento das Chagas (Negro Cosme) ${ }^{41}$.

Assim, é após um período de grande desorganização e prejuízo para a economia agroexportadora que começa a se formar o caldo cultural que contribuiria para a gênese da noção de Atenas Brasileira, a partir da geração que sucedeu o chamado "Grupo Maranhense" - grupo esse que teria seus maiores expoentes no poeta Gonçalves Dias, no jornalista e historiador João Francisco Lisboa, no filólogo Francisco Sotero dos Reis e no jornalista Manoel Odorico Mendes (a escritora negra Maria Firmina dos Reis, autora de contos, poemas e romances elogiados pela crítica da época, e também prima de Sotero dos Reis, teve seu nome e obra recorrentemente excluídos desse cânone) $)^{42}$. Com efeito, o primeiro registro histórico de aparição da expressão data de 1851, em um folhetim no qual João Lisboa - que posteriormente passaria a ser associado ao panteão "ateniense" - se posicionava de maneira crítica a esse emblema identitário. Já a segunda aparição se dá em 1859, em um jornal carioca, cujo correspondente em São Luís a emprega para falar do conjunto dos maranhenses, incluindo a si próprio. Segundo Luiz Fabiano Tavares (2012, p. 179), a essa época, “[a]pesar dos poucos registros escritos, a ideia parecia já circular na cidade com alguma regularidade, tendo densidade suficiente para gerar alguma inteligibilidade e mesmo ser criticada". Assim, a partir de meados do século XIX, após a Balaiada, tem lugar uma dinâmica de produção

exprimem um conjunto de reflexões, distintas e controversas, que giram em torno de um eixo comum. Mas o que é um emblema? Eu diria que é uma representação gráfica que torna visível um determinado aspecto da realidade, algo que condensa de maneira taquigráfica um significado que o constitui e ultrapassa. Por isso nos remete sempre a algo que o transcende, não se esgota na materialidade de seu significante" (ORTIZ, 2015, p. 10-11).

${ }^{41}$ Sobre a Balaiada, cf. Clóvis Moura (1988; 2004, p. 59-60).

42 Sobre Maria Firmina dos Reis, cf. a dissertação de Rafael Zin (2016). 
simbólica que passa pelo empenho das elites culturais do Maranhão ${ }^{43}$ em forjar para si um lugar de distinção.

Nesse sentido, acredito que é possível apontar, no caso do emblema da Atenas Brasileira, o mesmo traço que Renato Ortiz (2001, p. 162) observa no regionalismo pernambucano, já no início do século XX:

No momento em que a elite local perde o poder no processo de unificação nacional, tem-se o florescimento do estudo da cultura popular; um autor como Gilberto Freyre poderia talvez ser tomado como representante paradigmático dessa classe que procura reequilibrar seu capital político através da temática do regional.

Pois, como aponta Tavares (2012, p. 181),

a elite local passava por séria crise quanto à autoridade imperial; em meados do século a Província mantinha problemática relação com o Rio de Janeiro, quase visto como uma nova Lisboa a explorar o Maranhão.

No lugar de um regional apoiado na cultura popular, no entanto, se trataria de um regional baseado em uma cultura erudita (apesar de alguns desses intelectuais terem se interessado pela cultura oral, como é o caso de Celso Magalhães, pioneiro do folclorismo no Brasil). Essa vontade de diferenciação, pela via da nobreza cultural ${ }^{44}$, ofereceria assim uma compensação simbólica à decadência material ${ }^{45}$. Ao longo da segunda metade do século XIX,

\footnotetext{
${ }^{43}$ Em grande parte bacharéis, filhos da classe dominante, formados em Coimbra ou Olinda, por exemplo. "A ascensão dos bacharéis brancos se fez rapidamente no meio político, em particular, como no social, em geral. O começo do reinado de Pedro II é o que marca, entre outras alterações na fisionomia brasileira, o começo do 'romantismo jurídico' no Brasil, até então governado mais pelo bom senso dos velhos que pelo senso jurídico dos moços. [...] [F]oi com Pedro II que a nova mística - a do bacharel moço - como que se sistematizou, destruindo quase de todo a antiga: a do capitão-mor velho" (FREYRE, 2002, p. 1215).

44 "Contra a ideologia carismática segundo a qual os gostos, em matéria de cultura legítima, são considerados um dom da natureza, a observação científica mostra que as necessidades culturais são o produto da educação [...]. À hierarquia socialmente reconhecida das artes - e, no interior de cada uma delas -, dos gêneros, escolas ou épocas, corresponde a hierarquia social dos consumidores. Eis o que predispõe os gostos a funcionar como marcadores privilegiados da 'classe'. [...] A nobreza cultural possui, também, seus títulos discernidos pela escola, assim como sua ascendência pela qual é avaliada a antiguidade do acesso à nobreza. A definição de nobreza cultural é o pretexto para uma luta que, desde o século XVII até nossos dias, não deixou de opor, de maneira mais ou menos declarada, grupos separados em sua ideia sobre cultura, sobre a relação legítima com a cultura e com as obras de arte, portanto, sobre as condições de aquisição, cujo produto é precisamente estas disposições" (BOURDIEU, 2007, p. 9).

${ }^{45}$ As perspectivas oferecidas por Corrêa (1993), Lacroix (2000) e Costa (2001) contribuem para essa interpretação. "O culto àquela imagem da sociedade instruída, representada por uma constelação de estudiosos e intelectuais criativos, rendeu ao Maranhão o cognome de Atenas Brasileira e aos maranhenses o estatuto de atenienses, generalizando o que era mais imaginário que real, dissimulando a divisão concreta e efetiva daquela sociedade elitista e preconceituosa. Aludida mitologia cultivada pela classe dominante foi repetida, acreditada e transmitida para toda a sociedade [...]" (LACROIX apud NORONHA, 2015, p. 106).
} 
o emblema da Atenas Brasileira se consolidaria na vida intelectual maranhense, enquanto modo importante de auto-identificação dos produtores simbólicos locais. É sobre esse solo, sedimentado por gerações de intelectuais ao longo do Segundo Reinado, que aparecem, no começo do século XX, as primeiras discussões a respeito da arquitetura portuguesa colonial em São Luís.

\section{Figuração do preservacionismo}

Após esse preâmbulo, que é revelador de alguns aspectos da vida cultural no Maranhão do Segundo Reinado e, por extensão, das condições locais de produção simbólica naquele período e nas primeiras décadas da República, é possível proceder à construção da primeira figuração do processo de invenção do centro histórico de São Luís. Essa figuração corresponde ao momento decisivo que se estende das primeiras décadas do século $\mathrm{XX}$ até as décadas de 1960/1970 (quando pode-se marcar o início do segundo momento decisivo, o da reconstrução).

Alguns traços podem ser apontados como particularidades da figuração do preservacionismo: a eleição da arquitetura colonial como elemento identitário local, seu enquadramento através de um olhar estetizante e informado pela ideia de um valor de antiguidade, e a entrada de um certo pensamento preservacionista na razão de Estado, além da vontade de distinção pela via da nobreza cultural, caracterizada no preâmbulo acima. Esses traços, mediados pela cultura intelectual herdada do século XIX, convergiram assim para inventar a diferença significada pelo centro histórico de São Luís.

A pesquisadora Raquel Noronha (2015, p. 106), em trabalho que discute as representações sobre a noção de patrimônio na feira da Praia Grande, no centro de São Luís, levanta a seguinte hipótese:

Ao se deparar com um momento interpretado como de decadência, em que se verificaria uma ruptura histórica com um período vivido como de prosperidade, que teria se prolongado até o século XIX, os agentes sociais procuram legitimar suas posições no espaço social por meio da reinvenção das tradições. Apegam-se à noção de uma superioridade intelectual, agarram-se aos símbolos de um tempo próspero, e o conceito de preservação 
patrimonial surge, então, como instrumento de prolongamento desse passado.

Aqui, tomo essa sugestão como ponto de partida para perseguir, no tramado das interdependências sociofuncionais, os nexos do preservacionismo, isto é, a tomada de posição dos intelectuais que a partir da primeira metade do século XX contribuem para inventar o centro histórico de São Luís enquanto diferença. Dessa forma, a maneira que escolhi para conduzir essa análise figuracional foi a de examinar conjuntos de interdependências a partir das interseções de trajetórias sociobiográficas de indivíduos específicos. Esses indivíduos são entendidos não como sujeitos isolados e anteriores às relações sociais, mas sim como posições em uma trama de sentido mais ampla, que os conecta entre si e à paisagem da cidade.

$\mathrm{Na}$ passagem mencionada acima, Noronha destaca que a tentativa de prolongamento do passado tido como próspero se deu também através do conceito de "preservação patrimonial". Nesse sentido, o primeiro conjunto de indivíduos a serem analisados são aqueles que começam a apresentar e pôr em circulação, em escala local, o que se pode chamar de um pensamento preservacionista (pois é nesse pensamento que serão gestados os primeiros sentidos de diferenciação do que viria a ser classificado como o centro histórico de São Luís). Trata-se de compreender a agência desses indivíduos em seus cruzamentos, observando as afinidades e tensões funcionais que os conectam em uma mesma rede de posições.

Na trama de produtores simbólicos envolvidos nesse momento decisivo da invenção do centro histórico, adquirem relevo as atuações dos intelectuais que criam o primeiro agente estatal local explicitamente dedicado às práticas de preservação patrimonial: a Comissão do Patrimônio Artístico e Tradicional do Município, fundada em 1943. É possível tomar essas atuações, então, como indicações que permitem percorrer as linhas de força da figuração. Em sua dissertação Capital Moderna e Cidade Colonial: o pensamento preservacionista na história do urbanismo ludovicense, José Antônio Viana Lopes levanta várias informações empíricas relevantes sobre o período aqui enfocado, com a ajuda das quais será possível reconstituir alguns dos encadeamentos centrais dessa rede.

Segundo o autor,

no ano de 1943, por iniciativa de um grupo de intelectuais locais, coordenados por Antonio Lopes, a Prefeitura Municipal instalou a Comissão do Patrimônio Artístico e Tradicional, criada no código de posturas do 
Município, em 1936, mas que não fora efetivamente instalada naquele momento. (LOPES, 2004, p. 142)

Essa instalação se fez possível a partir de um decreto-lei do mesmo ano de 1943, que regulamentava a cooperação do poder público municipal com entidades culturais e de assistência social. Nesse contexto, a Comissão surge como uma extensão do Instituto Histórico e Geográfico do Maranhão, amparada no decreto que incluía o apoio do município a instituições que tratassem da "conservação do patrimônio cultural" (apud LOPES, 2004, p. 142). No entanto, quem eram os indivíduos que compunham esse grupo de intelectuais, que por sua vez consistiam nos primeiros quadros da Comissão? Segundo Viana Lopes,

[n]ão eram, como se poderia pensar, engenheiros ou arquitetos, mas desembargadores (Leopoldino Lisboa, Henrique Costa Fernandes), jornalistas (Fernando Perdigão), políticos (Luso Torres), advogados (Antonio Lopes), todos atuantes na imprensa local e vinculados às principais instituições culturais do estado, como a Academia Maranhense de Letras e o Instituto Histórico e Geográfico do Maranhão, e nacionais. Eram profissionais que atuavam em diversos campos e que já eram, naquele momento, reconhecidos como autoridades intelectuais da cidade. (LOPES, 2004, p. 143)

Esses produtores culturais, então, se reúnem na Comissão do Patrimônio Artístico e Tradicional com o objetivo de, segundo a redação do decreto de sua criação,

proceder ao reconhecimento e catalogação de todos os monumentos, edifícios, sítios e objetos que interessem ao patrimônio histórico e artístico da cidade e de propor ao Governo Municipal as medidas para a conservação desses tesouros. (apud LOPES, 2004, p. 142)

É no sentido dessa missão que, ainda no mesmo ano, e a partir da atuação da Comissão, a prefeitura decreta proibida a demolição ou remodelação de edificações dotadas de mirantes ou revestimento de azulejos, com a justificativa de conservar "o aspecto tradicional e, mesmo, peculiar da cidade" (apud LOPES, 2004, p. 146). Dessa forma, tem-se uma figuração na qual invenção de tradição e política da imagem, tais como definidas no segundo capítulo, coincidem. A tomada de posição em favor dos mirantes e azulejos constitui, assim, uma atribuição de sentido que adquire força programática, fixando em imagem e em paisagem, e com consequências duráveis (cf. foto da p. 50), a identidade cultural local. Isso 
acontece em uma conjuntura que não é livre de tensões, pois essa decisão aparece como reação a uma série de medidas modernizantes que previam a "remodelação" da paisagem da cidade antiga.

Entretanto, falta ainda explicar como a figuração descrita acima plasma um processo social - um fluxo de atribuição de sentido - cuja gênese lhe é anterior. A trama formada por esses intelectuais é tributária de movimentações que existem pelo menos desde a década de 1910; com efeito, segundo um gestor público entrevistado por Noronha (2015, p. 103), “desde o início do século, desde 1917, já há uma série de intelectuais que começam a estruturar um discurso preservacionista”. De acordo com a mesma fonte,

[a] gente tem uma série de artigos, de intelectuais respeitados aqui de São Luís, defendendo a questão do patrimônio, e aí é interessante perceber o foco que eles davam naquele momento, havia diversas correntes de pensamento. [...] E eram discursos extremamente elaborados, e antes de chegarem nas revistas, a gente tem discursos na Academia Maranhense de Letras, na revista do Instituto Histórico, mas antes de chegar nas revistas eles eram publicados em jornais, eram artigos de debates públicos, e eu acredito que esse processo gerou, vamos dizer, uma mentalidade preservacionista, que também atuou, colaborou na preservação desse acervo. (apud NORONHA, 2015, p. 104)

Na legislação estadual, a menção à preservação de monumentos existe pelo menos desde 1927, quando uma Lei Orgânica dos Municípios atribui a estes últimos a tarefa de conservar "parques, jardins, logradouros públicos e monumentos" (apud LOPES, 2004, p. 31). No entanto, essa lei ainda não reconhece o chamado "patrimônio histórico e artístico" como especificidade, subsumindo-o na categoria mais geral de "patrimônio público". (Já no trecho do decreto de criação da comissão, transcrito acima, a categoria de "patrimônio histórico e artístico" aparece explicitamente.) Nesses mesmos anos de 1927 e 1928, Bahia e Pernambuco já introduzem leis estaduais com o objetivo de proteger os bens materiais considerados como portadores de valor histórico. Em Pernambuco, é criada uma "Inspetoria Estadual de Monumentos Nacionais" (CANTARELLI, 2014), idealizada por figuras públicas como Gilberto Freyre. Em Minas Gerais, esforços desse tipo datam de 1925.

Enquanto isso, na Europa, realiza-se em 1933 o IV Congresso Internacional de Arquitetura Moderna (CIAM), cujo principal resultado foi a influente Carta de Atenas, redigida e publicada por Le Corbusier. Embora orientado pelo valor modernista da 
funcionalidade urbana, este último documento contemplava também as edificações legadas pelo passado, prescrevendo que "os valores arquitetônicos devem ser salvaguardados (edifícios isolados ou conjuntos urbanos)", com a ressalva de que "eles serão salvaguardados se constituírem expressão de uma cultura anterior e se corresponderem a um interesse geral", pois "nem tudo que é passado tem, por definição, direito à perenidade; convém escolher com sabedoria o que deve ser respeitado" (LE CORBUSIER, 1993). No mesmo ano de 1933, no Brasil, um decreto ${ }^{46}$ assinado por Getúlio Vargas declarava a cidade de Ouro Preto como "monumento nacional”, já reconhecendo "os monumentos ligados à História Pátria" e as "obras de arte" como parte de um "patrimônio histórico e artístico" da cidade.

É nesse cenário nacional e internacional que se desenha, a partir de 1936, a criação de um órgão nacional direcionado à preservação dos bens interpretados como dotados de valor histórico e artístico. (Antes disso, ideias de leis orientadas à proteção desses bens já circulavam no Congresso Nacional desde a década de 1920.) Esse órgão, chamado de Serviço do Patrimônio Histórico e Artístico Nacional (SPHAN) ${ }^{47}$, surgiria a partir da iniciativa de Gustavo Capanema, ministro da Educação e Saúde de Getúlio Vargas de 1934 a 1945. Segundo a narrativa oficial da instituição (IPHAN, 1980, p. 12-13), o ministro contou com a ajuda de Mário de Andrade, então diretor do Departamento de Cultura da Prefeitura de São Paulo, que redigiu o primeiro projeto de implementação do serviço. Dado o aval do presidente da república, foi organizado em 1936 o SPHAN, para cuja direção Mário de Andrade sugeriu o nome de Rodrigo Melo Franco de Andrade, mineiro assim como Capanema. Por ocasião do surgimento desse novo arranjo institucional, em 1936, o jornal carioca Diário da Noite relatava nos seguintes termos uma entrevista com o diretor do SPHAN:

Nos países civilizados - conclui o dr. Rodrigo Melo Franco de Andrade -, isso já está plenamente organizado. Recentemente se reuniu em Atenas uma conferência internacional para assentar, na órbita mundial, as mesmas e oportunas medidas que o nosso Serviço objetiva e sob o alto e inspirado sentido de que os patrimônios históricos e artísticos nacionais transcendem e são de interesse da comunidade universal. (ANDRADE, 1987, p. 25)

Tal declaração ajuda a evidenciar a circulação transnacional das ideias preservacionistas. Contudo, é provável que a referência de Franco de Andrade não seja à Carta de Atenas de

\footnotetext{
${ }^{46}$ Decreto $\mathrm{n}^{\mathrm{o}}$ 22.928, de 1933. Disponível em: http://www2.camara.leg.br/legin/fed/decret/1930-1939/decreto22928-12-julho-1933-558869-publicacaooriginal-80541-pe.html . Acesso em 13/11/2017.

${ }^{47}$ Sobre a criação do SPHAN, cf. Mariza Veloso (1992) e Maria Cecília Londres Fonseca (1997).
} 
1933, mencionada acima, e sim à primeira Conferência Internacional para a Conservação dos Monumentos Históricos, ocorrida na mesma cidade dois anos antes, e que resultou também em um documento conhecido como "Carta do Restauro".

Voltando mais especificamente à teia do preservacionismo no Maranhão, em cujo meio é engendrado o primeiro momento decisivo da invenção do centro histórico de São Luís, cumpre examinar com mais proximidade as trajetórias sociobiográficas de dois indivíduos ocupantes de posições-chave no interior dessa figuração: tratam-se dos irmãos Antonio e Raimundo Lopes da Cunha.

Ambos nasceram nos últimos anos do século XIX, na cidade maranhense de Viana, e eram filhos de Manuel Lopes da Cunha, desembargador e governador do estado por alguns meses durante o ano de 1902, além de sobrinhos do escritor e folclorista Celso Magalhães. Antonio Lopes da Cunha (1889 - 1950) fez seus estudos secundários no Rio de Janeiro, onde a família residiu na primeira década do século XX. Formou-se em ciências jurídicas no Recife, em 1911, e em 1918 foi um dos fundadores da Faculdade de Direito de São Luís. Manteve atividade jornalística, tendo seus primeiros artigos sido escritos durante a formação em Pernambuco e enviados para publicação no Diário do Maranhão. Lecionou no Liceu Maranhense e na Faculdade de Direito e foi diretor da Instrução Municipal. Foi um dos fundadores do Instituto Histórico e Geográfico do Maranhão e membro da Academia Maranhense de Letras. Publicou Alcântara - Subsídios para a história da cidade e Presença do Romanceiro, sobre a literatura oral no Maranhão, e revisou e ampliou o Dicionário Histórico-Geográfico da Província do Maranhão, obra de referência editada pela primeira vez em 1870.

Raimundo Lopes da Cunha (1894-1941) durante a infância morou no Rio de Janeiro com a família. Estudou no Liceu Maranhense e escreveu precocemente $O$ Torrão Maranhense, ensaio de geografia humana. Também manteve atividade jornalística. Era bacharel em letras, cursou um ano da Escola Politécnica do Rio de Janeiro e quatro anos de direito, interrompendo para dedicar-se à pesquisa nas áreas da geografia, arqueologia e etnologia na então capital da República. Na década de 1930, até sua morte em 1941, foi arqueólogo e etnólogo do Museu Nacional. Foi membro do Instituto Histórico e Geográfico do Maranhão e da Academia Maranhense de Letras. Deu palestras na rádio do Ministério da Educação, publicou obras científicas e, elo importante, o artigo A Natureza e os Monumentos Culturais no primeiro número da Revista do SPHAN, editado em 1937. Nesse texto, ele 
defende a proteção de sítios arqueológicos próximos a São Luís, além de se posicionar a favor do estilo arquitetônico neocolonial (LOPES, 2004, p. 167). Sobre Raimundo Lopes, um dos interlocutores de Raquel Noronha afirma que "tinha uma influência muito forte no IPHAN no Rio de Janeiro" (apud NORONHA, 2015, p. 111). ${ }^{48}$

Para os propósitos aqui perseguidos, toma relevo, nos escritos de Antônio Lopes, um artigo publicado em 1926 no primeiro número da revista do Instituto Histórico e Geográfico do Maranhão, intitulado A Cidade de São Luíz: vestígios do passado. Nele, o autor faz um inventário de bens móveis e imóveis tidos como de valor histórico. Um ano depois, em 1927, ele se engaja, com sucesso, em campanha contrária à demolição das ruínas da Igreja Matriz da cidade de Alcântara. Nessa ocasião, ele exortaria um poeta contemporâneo seu a juntar-se às fileiras do preservacionismo: "[b]ata-se, caro poeta, pela conservação das ruínas, monte guarda empunhando seu alfange, a essas testemunhas de tempos memoráveis" (apud LOPES, 2004, p. 80). Em As Inscrições Lapidares de São Luís, texto de 1943, o autor faz a crítica de uma política da imagem pregressa, representada por um decreto de 1896 que instituía a substituição dos beirais tradicionais da arquitetura portuguesa por platibandas à moda do estilo eclético, atribuindo a essa política as "incríveis mutilações" sofridas pela cidade (LOPES, 2004, p. 81).

Além disso, em seu próprio tempo Antonio Lopes travou polêmicas contra medidas que alteravam a fisionomia "tradicional" da cidade. Essas polêmicas evidenciam o componente de tensão que se faz presente nessa figuração, e a forma particular que esse equilíbrio dinâmico toma. Pois a política da imagem proposta pelos intelectuais preservacionistas possui também um caráter reativo, já que incide como reposta às remodelações "haussmanianas" implementadas pelas administrações de Saboya Ribeiro (1937) e Pedro Neiva de Santana (1937-1945) na prefeitura do município, no período do Estado Novo. O primeiro era engenheiro formado pela Escola Politécnica do Rio de Janeiro e tinha atuação na capital durante os anos 30, e o segundo era médico também formado na Faculdade de Medicina do Rio, tendo sido ambos indicados pelo interventor federal Paulo Ramos.

\footnotetext{
48 Informações biográficas colhidas em Lopes (2004) e no site da Academia Vianense de Letras (http://www.avlma.com.br/).
} 
Um exemplo das mudanças desse período foi a obra de alargamento da Rua Grande, em 1939, que implicou na demolição da Igreja de Nossa Senhora da Conceição dos Mulatos. Segundo Viana Lopes (2004, p. 131), essa mesma obra

teria motivado as primeiras ações federais de preservação do acervo ludovicense, e a Capela de São José da Quinta das Laranjeiras e o Portão Armoriado da Quinta das Laranjeiras são tombados pelo SPHAN como patrimônios históricos e artísticos nacionais em 1940, a partir de indicações e orientação dos intelectuais locais que, desde 1937, mantinham relações de colaboração com o órgão federal.

Por volta da mesma época, em 1938, Astolfo Serra, interventor no estado logo após revolução de 30, saudava no jornal $O$ Imparcial tanto a modernização quanto a preservação, descrevendo os sobrados coloniais como "relíquias sagradas desse passado áureo do Maranhão, que do alto de seus mirantes contemplam a cidade que avança inevitavelmente em progresso e em civilização" (apud LOPES, 2004, p. 124).

Já na atuação de Raimundo Lopes da Cunha, tomam relevo textos como um artigo de 1917, sobre Os Fortes Coloniais de São Luís, e o livro O Torrão Maranhense, também tão antigo quanto 1916, ensaio em que o autor reconhecia na cidade de Alcântara "a poesia do passado, da grandeza perdida, das relíquias veneráveis, vítimas, não do tempo, mas da incúria e do vandalismo" (apud LOPES, 2004, p. 63) ${ }^{49}$. Mais tarde, em 1937, publicaria o já mencionado A Natureza e os Monumentos Culturais no primeiro número da Revista do Patrimônio Histórico e Artístico Nacional, em edição que também contava com contribuições de Lúcio Costa, Mário de Andrade e Gilberto Freyre. Nesse texto, ele faz um estudo comparativo dos "caracteres antropogeográficos das cidades históricas", discorrendo também sobre sítios arqueológicos do Maranhão. A atenção reservada a estes últimos culminaria com o primeiro tombamento federal no estado, a partir de indicações de Raimundo Lopes: o do sambaqui do Pindaí, no começo de 1940.

Além das trajetórias sociais dos irmãos Lopes da Cunha, poderiam também ser destacadas outras atuações, como a de José Luso Torres, deputado e militar nacionalista, que

\footnotetext{
${ }^{49}$ Nesse trecho é possível notar um elemento de nostalgia que também comparece em momentos posteriores. Penso que uma duração contemporânea desse sentimento nostálgico pode ser observada no hábito, comum entre famílias das classes médias e altas maranhenses, de manter em suas casas e apartamentos - distantes do centro histórico - pinturas de paisagens dessa parte da cidade (cf. foto da p. 52). Em A Sociedade de Corte, Norbert Elias descreve o modo como a curialização da nobreza de espada residente no campo, isto é, sua transformação em nobreza de corte, engendra também o que ele chama de um nostálgico "romantismo aristocrático", traduzido no gosto por imagens e descrições idílicas da vida campestre.
} 
em discurso quando da instalação da Comissão do Patrimônio Artístico e Tradicional procurou dar um tom nacional à sua missão:

o passado maranhense, o passado baiano, os passados de todas as unidades da federação são correntes de uma só convergência histórica que é o passado do Brasil. O sentido de nossa missão é, pois, alta e essencialmente nacionalista. (apud LOPES, 2004, p. 88)

Por fim, um último aspecto merece ser ressaltado. Vimos acima que a Comissão do Patrimônio Artístico e Tradicional do Município, criada em 1943, surge como extensão das atividades do Instituto Histórico e Geográfico do Maranhão, sendo Antonio Lopes da Cunha líder da primeira e fundador do segundo. Que as práticas patrimoniais - ou uma versão primitiva delas - tenham aparecido em escala local em meio a uma rede de interdependências que atravessa o Instituto Histórico e Geográfico é um fato digno de atenção. Pois, segundo Edson Farias (2007, p. 122),

a função de autocoordenação estatal exercida pelo Império, a princípio, esteve na contrapartida dos esforços em conferir profundidade histórica à idéia de Brasil. A fundação do Instituto Histórico Geográfico Brasileiro, e das suas versões regionais, fora movida por tal propósito, sendo a base de uma historiografia nacional e, no mesmo andamento, consistiu na pavimentação visando dotar a formação nacional de um traço de continuidade. [...] [N]o caso do Brasil imperial o tema em pauta consistia, para o recente Estado central, no ajuste em sua unidade institucionaladministrativa e jurídica de termos humanos e simbólicos tão heteróclitos e dispostos em estruturas político-econômicas também distintas, mas caudatárias de fórmulas suscetíveis de promover a desigualdade socioeconômica e a estigmatização de grupos. Portanto, o dado espinhoso para os intelectuais comprometidos com o Império consistia em fornecer quadros de pensamento e percepção capazes de concatenar sem ferir a medula óssea patrimonial e escravista, além de corroborar a específica situação de permanência da dinastia real perfilhada na antiga metrópole.

Apesar da criação tardia da versão maranhense do Instituto Histórico e Geográfico, apenas em 1925, com quase cem anos de atraso (sendo o IHGB de 1838), penso que é possível extrapolar a interpretação acima para o caso específico de invenção de tradição aqui enfocado. Trata-se, nesse sentido, da elaboração de uma narrativa identitária englobante a 
respeito da cidade, que, no entanto, parte de uma posição social específica. No interior dessa narrativa, os primeiros elementos selecionados para ser fixados como a imagem do tempo da “grandeza perdida”, nas palavras de Raimundo Lopes, são justamente os sobrados dotados de azulejos e mirantes, típicos não só da arquitetura civil portuguesa, em geral, mas também do estilo pombalino predominante à época da prosperidade da lavoura maranhense. Que essa "grandeza perdida" tenha repousado sobre a escravidão é algo consciente ou inconscientemente ignorado.

Sintetizando a análise dessa figuração, assim, tem-se uma elite cultural de bacharéis que é simultaneamente classe dirigente ${ }^{50}$, a exemplo dos irmãos Lopes da Cunha, que tende a funcionar como organizadora da cultura e que constrói a imagem da cidade colonial dotada de uma tradição e uma arte próprias, das quais a arquitetura seria expressão. Isso constitui um primeiro grande fluxo de atribuição de sentido à paisagem do centro antigo de São Luís (ao mesmo tempo em que uma política da imagem ajuda a produzir essa paisagem). Entre 1927, ano da Lei Orgânica dos Municípios que prevê de maneira genérica a preservação de monumentos, e 1943, data da criação da Comissão do Patrimônio Artístico e Tradicional do Município, chega a essa elite e à razão de Estado local a categoria de "patrimônio histórico e artístico". A categoria espacial "centro histórico", no entanto, só apareceria explicitamente um pouco mais tarde.

\section{Digressão: patrimônio histórico e artístico como ideia fora do lugar}

Defender o nosso patrimônio histórico e artístico é alfabetização.

Mário de Andrade

O modernismo é uma ideia fora do lugar que se expressa como projeto.

Renato Ortiz, A Moderna Tradição Brasileira

Um problema colocado por sucessivas gerações de intelectuais brasileiros, e revisitado por mais de um analista contemporâneo (CANCLINI, 1998; ORTIZ, 2001; SCHWARZ,

\footnotetext{
50 "O direito não exprime toda a sociedade (pelo que os violadores do direito seriam seres anti-sociais por natureza, ou deficientes mentais), mas a classe dirigente, que 'impõe' a toda a sociedade aquelas normas de conduta que estão mais ligadas à sua razão de ser e ao seu desenvolvimento" (GRAMSCI, 2007, p. 249).
} 
1987, 2008), é aquele que se constitui em torno do sentimento de inorganicidade e/ou inautenticidade da vida cultural conduzida no país por suas elites letradas. As linhas iniciais de Raízes do Brasil sintetizam a questão:

A tentativa de implantação da cultura européia em extenso território, dotado de condições naturais, se não adversas, largamente estranhas à sua tradição milenar, é, nas origens da sociedade brasileira, o fato dominante e mais rico em consequiências. Trazendo de países distantes nossas formas de convívio, nossas instituições, nossas idéias, e timbrando em manter tudo isso em ambiente muitas vezes desfavorável e hostil, somos ainda hoje uns desterrados em nossa terra. (HOLANDA, 1995, p. 31)

Porém, como afirma Roberto Schwarz em Nacional por Subtração, o problema em muito precede o momento modernista de construção da nação, sendo sua gênese tão remota quanto o século XIX:

Brasileiros e latino-americanos fazemos constantemente a experiência do caráter postiço, inautêntico, imitado da vida cultural que levamos. Essa experiência tem sido um dado formador de nossa reflexão crítica desde os tempos da Independência. Ela pode ser e foi interpretada de muitas maneiras, por românticos, naturalistas, modernistas, esquerda, direita, cosmopolitas, nacionalistas etc., o que faz supor que corresponda a um problema durável e de fundo. (SCHWARZ, 1987, p. 29)

Essa experiência de inautenticidade se traduziria em um mal-estar presente em várias situações cotidianas da vida social, constituindo um "sentimento da contradição entre a realidade nacional e o prestígio ideológico dos países que nos servem de modelo" (SCHWARZ, 1987, p. 30). Revisando os contornos da problemática, contudo, Schwarz a recoloca em termos não de autenticidade, mas de desajuste:

[É] certo também que as formas e técnicas - literárias e outras - que se adotam nos momentos de modernização foram criadas a partir de condições sociais muito diversas das nossas, e que a sua importação produz um desajuste que é um traço constante de nossa civilização. (SCHWARZ, 2008, p. 137)

A elaboração faz eco, de certa forma, a outro texto importante do autor, publicado em 1977. Em As ideias fora do lugar, ensaio que abre o estudo dedicado a Machado de Assis, ele 
analisa os movimentos da vida ideológica brasileira à época deste autor, em um contexto no qual o liberalismo, de importação europeia, dava a tônica. Segundo o argumento central de Schwarz (2000), “a liberdade do trabalho, a igualdade perante a lei e, de modo geral, o universalismo eram ideologia na Europa também; mas lá correspondiam às aparências, encobrindo o essencial - a exploração do trabalho"; enquanto, no Brasil, tais valores burgueses abstratos, acolhidos pelas elites locais, não poderiam se apresentar sequer como aparência: eram negados de forma explícita pela realidade concreta da escravidão. Resumindo, o resultado desse arranjo não é o cancelamento de um dos polos, ou a superação da contradição, e sim a perpetuação desta última enquanto tal, na forma de um equilíbrio dinâmico particular. Nas palavras do autor, "este antagonismo [entre liberalismo e escravismo] produziu, portanto, uma coexistência estabilizada [...]. Sem prejuízo de existir, o antagonismo se desfaz em fumaça e os incompatíveis saem de mãos dadas" (SCHWARZ, 2000). O que se cancela, assim, é o "teste da realidade", de modo que as ideias liberais passam a funcionar tão somente como ornamento, sendo cimento de uma solidariedade entre privilegiados, baseada na troca de favores. Esse manejo contingente das ideias, por sobre a realidade prática da troca de dádivas ${ }^{51}$ de membros das classes dominantes entre si e com seus dependentes, é captado pela própria ficção de Machado de Assis, que no conto Teoria do Medalhão já expunha os conselhos dados por um patriarca a seu herdeiro:

Toda a questão é não infringir as regras e obrigações capitais. Podes pertencer a qualquer partido, liberal ou conservador, republicano ou ultramontano, com a cláusula única de não ligar nenhuma idéia especial a esses vocábulos. (ASSIS, 1994)

Embora se concentre no liberalismo brasileiro do século XIX, o modelo analítico de Schwarz viria a ganhar em influência e abrangência, passando a ser aplicado a outros contextos. É assim que Renato Ortiz (2001, p. 35), em A Moderna Tradição Brasileira, dá o diagnóstico de que "o modernismo é uma ideia fora do lugar que se expressa como projeto". Para o autor, assim como o liberalismo "serve como ornamento de civilização, mas não possui força histórica para transformar organicamente a sociedade como um todo", também "o mesmo pode ser argumentado em relação ao conceito de moderno na sociedade brasileira", pois “a noção de modernidade está 'fora do lugar' na medida em que o Modernismo ocorre no

\footnotetext{
51 "São, antes de tudo, amabilidades, banquetes, ritos, serviços militares, mulheres, crianças, danças, festas, feiras, dos quais o mercado é apenas um dos momentos, e nos quais a circulação de riquezas não é senão um dos termos de um contrato bem mais geral e bem mais permanente. Enfim, essas prestações e contra-prestações se estabelecem de uma forma sobretudo voluntária, por meio de regalos, presentes, embora elas sejam no fundo rigorosamente obrigatórias, sob pena de guerra privada ou pública” (MAUSS, 2003, p. 191).
} 
Brasil sem modernização". Exemplo disso seria o descompasso que se revela entre os manifestos brasileiros da década de 20, por um lado, e a realidade social, por outro, sendo os primeiros tidos como "antecipadores" de processos posteriormente concretizados. Esse "hiato entre intenção e realização" se torna assim uma forma de "inadequação de determinadas concepções em relação à totalidade da sociedade" (ORTIZ, 2001, p. 30-32).

Dialogando criticamente com essa formulação, Néstor García Canclini (1998, p. 71) pondera, a partir da referência a um artigo de Perry Anderson sobre a relação entre modernismo e modernidade na Europa, que o erro "surge de comparar nossa modernidade com imagens otimizadas de como esse processo aconteceu nos países centrais”. Nesse sentido, também a modernização dos países centrais teria se dado em um descompasso entre diferentes temporalidades e, em comparação com um ideal normativo de organicidade, os arranjos nacionais periféricos seriam sempre inevitavelmente considerados inorgânicos. Segundo a leitura de Canclini (1998, p. 72),

[o]s movimentos modernistas surgem na Europa continental, não onde ocorrem transformações modernizadoras estruturais, diz Anderson, mas onde existem conjunturas complexas, 'a interseção de diferentes temporalidades históricas'.

Assim, o modernismo europeu, segundo Anderson, aparece ao mesmo tempo em que surge "na intersecção de uma ordem dominante semi-aristocrática uma economia capitalista semi-industrializada e um movimento operário semi-emergente ou semi-insurgente". Para Canclini, isso significa que o modernismo "não é a expressão da modernização socioeconômica mas o modo como as elites se encarregam da intersecção de diferentes temporalidades históricas e tratam de elaborar com elas um projeto global”. Dessa forma, os países latino-americanos seriam "atualmente resultado da sedimentação, justaposição e entrecruzamento de tradições indígenas (sobretudo nas áreas mesoamericana e andina), do hispanismo colonial católico e das ações políticas educativas e comunicacionais modernas" (CANCLINI, 1998, p. 73). No caso do Brasil e da cidade de São Luís, seria necessário acrescentar a essas matrizes a diáspora africana, na forma do pertencimento ao que Paul Gilroy (2001) chamou de Atlântico negro.

Postas essas perspectivas, e pensando com o esquema formulado por Schwarz, qual seria o lugar da ideia - engendrada pelo modernismo - de um patrimônio histórico e artístico 
nacional? E a cultura intelectual da "Atenas Brasileira", como se situaria nesse quadro marcado por uma tensão de desajuste entre "pessoas educadas" ${ }^{\text {"52 }}$ e a realidade brasileira?

Começando com uma indicação na direção desta última questão, vale a pena retomar a crítica mordaz de Aluísio Azevedo, exposta em epígrafe acima, à ideia de uma Atenas Brasileira equatorial. No mesmo artigo, após acusar o Maranhão de ser uma província "sem caráter nacional", o escritor segue afirmando:

O autor dessas linhas [...] não hesita a declarar que, por ocasião de publicar aí o romance $O$ mulato, enquanto no Rio de Janeiro, São Paulo e Pernambuco erguiam-se Joaquim Serra, Valentim Magalhães, Tobias Barreto, Urbano Duarte, Clóvis Bevilaqua, Araripe Júnior, Sá Viana, Capistrano de Abreu, Alcides Lima e muitas outras penas de igual valor, procurando animá-lo a prosseguir, ela, a tal Atenas de contrabando, só encontrava descomposturas para atirar sobre seu filho romancista. (AZEVEDO apud TAVARES, 2012, p. 177; grifo meu)

O tom da crítica, assim, é dado pela ideia de uma "Atenas de contrabando"; isto é, Atenas inautêntica, porque importada sem a mediação devida. Borralho também recupera um trecho de um jornal de 1880, em que o articulista João Affonso denuncia a incongruência entre o emblema ateniense e as práticas sociais efetivas:

No Maranhão, uma cidade lotada em 30.000 habitantes, intitulada Athenas, onde os poetas brotam espontaneamente como os cryptogramas, onde as questões grammaticaes assumem o caracter das internacionais, onde circulam três volumes de Pantheon cheios de gente immortal, onde a rhetorica é uma preocupação - no Maranhão não se lê, fecha-se uma casa de livros [o Gabinete Português de Leitura] porque ninguem a procura. (AFFONSO apud BORRALHO, 2009, p. 42)

Uma sociologia histórica das práticas de leitura e da circulação editorial provavelmente apontaria os padrões de mudança e continuidade desse arranjo. A título de exemplo, durante o percurso desta pesquisa, mais de uma vez procurei livros de publicação relativamente recente, muitos dos quais editados por órgãos públicos, mas que não foi possível achar em nenhuma livraria e nem na Biblioteca do Estado. Nesse sentido, sem

\footnotetext{
52 "Em síntese, desde o século passado existe entre as pessoas educadas do Brasil - o que é uma categoria social, mais do que um elogio - o sentimento de viverem entre instituições e ideias que são copiadas do estrangeiro e não refletem a realidade local" (SCHWARZ, 1987, p. 38-9).
} 
encerrar a questão de maneira conclusiva, é possível identificar na observação de Affonso um elemento que aponta para o desajuste da identidade de Atenas Brasileira, em relação à realidade mais ampla de um estado cuja taxa de analfabetismo em 2009 era de $15 \%$.

No que se refere ao tema mais específico desta digressão, a saber, as tensões funcionais que acompanham a ideia de patrimônio histórico e artístico no interior da configuração mais geral da produção simbólica no Brasil, Sérgio Miceli propõe uma avaliação que também pode ser sublinhada. Segundo o autor, essa ideia de patrimônio e sua expressão institucional, na forma do SPHAN, são um capítulo da história da geração modernista no Brasil, assim como também

um capítulo pouco conhecido mas prestigioso da história contemporânea das elites brasileiras, ou melhor, a amostra requintada e reverenciada das culminâncias de seu universo simbólico e, ao mesmo tempo, o inventário, arrolado à sua imagem e semelhança, dos grandes feitos, obras e personagens do passado. A política do patrimônio ostenta essa marca classista em tudo o que lhe diz respeito. (MICELI, 2001, p. 360)

Dessa forma, essa geração de intelectuais e políticos, com destaque para os mineiros, parte do legado barroco para propor a valorização de um repertório específico, selecionado por ela própria para compor a "memória nacional". Mariza Veloso recupera, por exemplo, um artigo de 1916 (mesmo ano de O Torrão Maranhense, de Raimundo Lopes), assinado por Alceu Amoroso Lima, no qual ele recorda uma viagem realizada na companhia de Rodrigo Melo Franco de Andrade à casa do avô deste último, em Ouro Preto. Nesse artigo, intitulado Pelo passado nacional, Amoroso Lima relatava as impressões profundas causadas pela visão da antiga capital mineira:

Por algum tempo, curto em dias, mas longo em meditação e saudade, conversei às sombras dos nossos mortos, de um discurso social que tem como objeto a nação, percebida nas ruínas de nossas paisagens. (apud VELOSO, 1992, p. 21)

No entanto, creio que não é somente essa "marca classista" da ideia de patrimônio histórico e artístico nacional, por si só, que faz dela "fora do lugar", no sentido de Schwarz. Além de apontar a imbricação da ideia de patrimônio, tal como foi predominantemente

53 http://g1.globo.com/educacao/noticia/2010/12/analfabetismo-cai-no-brasil-mas-aumenta-em-cinco-estadosdiz-ipea.html . 
pensada até a década de $1970^{54}$, com o quadro de valores estéticos de uma elite, seria necessário também atentar, tal como indicado por Canclini (1998, p. 69), para a "renovação das ideias mas com baixa eficácia nos processos sociais".

Nesse sentido, o autor cita uma afirmação de Mário de Andrade, na qual esse mesmo organizador da cultura que propunha a defesa do patrimônio histórico e artístico como uma forma de "alfabetização" também considerava que o modernismo era um setor "isolado e escudado em sua própria conviç̧ão” (apud CANCLINI, 1998, p. 80). Para Canclini (1998, p. 75), escritores e artistas latino-americanos frequentemente estiveram às voltas com "os conflitos internos de suas sociedades e com os obstáculos para comunicar-se com seus povos"; quadro esse que certamente ocorre no Brasil, país em que as distâncias sociais herdadas do escravismo ainda hoje estão longe de ser revogadas.

Quanto ao contexto maranhense, mais especificamente, Maria de Lourdes Lauande Lacroix (2012, 558-559), em mais uma expressão do sentimento de inadequação identificado por Schwarz, avalia que

[e]sta é a cidade de São Luís, cujo perímetro antigo, parte integrante e representativa das páginas da história colonial e imperial, possui atualmente 5.500 edificações, que deveriam ser melhor cuidadas, numa época de mudança de concepção e valorização do passado. Hoje, a tendência é da restauração e conservação de antigos imóveis das grandes cidades europeias, do casario medieval e moderno em harmonia com o contemporâneo. O Maranhão, no entanto, continua descompassado das políticas de conservação do patrimônio histórico e do meio ambiente.

Desse ponto de vista, a preservação do patrimônio, defendida pela autora e referenciada na Europa, permanece como ideia inefetiva. Também não há razão para pensar que questões semelhantes tenham passado sem ser enfrentadas pelos ocupantes das posições institucionais encarregadas da questão do patrimônio. A título de exemplo, o antropólogo Antonio Augusto Arantes (2006, p. 427), presidente do IPHAN de 2004 a 2006, considera, a respeito da prática de tombamento de bens culturais, que

\footnotetext{
${ }^{54}$ Nos anos 80 se inicia um processo de revisão dessa ideia, e sua reorientação no sentido de incluir também manifestações culturais das matrizes afro-indígenas, muitas vezes expressas em modos de vida e na cultura oral, culminando com o surgimento da categoria de "patrimônio imaterial", e de uma política correlata, no fim do século XX (cf. FONSECA, 1997).
} 
sentidos envolvendo coletividades mais abrangentes são sobrepostos a outros localmente atribuídos aos bens selecionados (religiosos, práticos, afetivos), pondo em contato e tensionando realidades de diferentes escalas: local, regional, nacional e, até, mundial. Essa tensão entre os sentidos enraizados nas práticas devolvidas pelos grupos sociais detentores dos bens selecionados e aqueles atribuídos por instâncias sociais mais inclusivas, mediada pela ação das agências e agentes institucionais, torna-se dessa forma constitutiva do bem patrimonial.

De certa forma, tudo se passa como se, em toda tentativa de construção de um patrimônio cultural nacional, houvesse um pouco da utopia que José Miguel Wisnik (2015, p. 61) identificou em Mário de Andrade: "redimir o abismo social pela cultura". Como seria possível reunir em um mesmo patrimônio cultural indivíduos e grupos submetidos a condições de vida tão díspares e iníquas? Por outro lado, como lembra Renato Ortiz (2001, p. 13), "falar em cultura brasileira é discutir os destinos políticos de um país".

As elaborações generalizantes, à maneira da ideia de um patrimônio histórico e artístico nacional, são tentativas de operacionalização prática de valores abstratos cuja significação varia com o contexto. Assim, tem-se uma disputa, de certa forma em aberto, pela fixação dos sentidos "autênticos" do nacional ou do regional. Um exemplo disso seria a formulação de Antonio Lopes da Cunha, nos anos 40, que se refere às inovações da arquitetura eclética ludovicense nos seguintes termos:

[C]asas de azulejo ou de mirante e sobrados antigos foram demolidos para no seu lugar construírem prédios de estilo bastardo, rascunhados ao sabor do mais extravagante ou ingênuo espírito de aldeia. (apud LOPES, 2004, p. 81; grifo meu)

No caso da modernização de São Luís, onde está o provincianismo e onde está o cosmopolitismo? Cosmopolita é o preservacionista Antonio Lopes, que luta, contra o "espírito de aldeia", a favor dos símbolos de sua aldeia, em uma versão distorcida da frase de Tolstói segundo a qual "fale de sua aldeia e estará falando do mundo"? Ou cosmopolitas são os defensores da marcha demolidora do progresso - definido pelos critérios importados da Europa moderna -, contra a herança ultrapassada da arquitetura colonial? Para Antonio Lopes, provinciano seria achar que cosmopolita é a destruição do que é local. Onde está a verdade? 
Para Canclini (1998, p. 77), “[a]vançamos pouco se acusamos as ideias liberais de falsas. Por acaso era possível descartá-las? Mais interessante é acompanhar seu jogo simultâneo com a verdade e a falsidade”. O mesmo, penso, poderia ser dito da ideia de patrimônio histórico e artístico e de sua operacionalização. Não se trata de uma inautenticidade essencial, simplesmente, mas antes de um modo de existência tenso que, como apontava Sérgio Buarque na passagem citada acima, acompanha as formas culturais trazidas "de países distantes" e acomodadas ao "ambiente hostil" brasileiro (incluindo-se entre elas o próprio nacionalismo e o Estado-nação burguês). Nessa perspectiva, o desajuste passa a ser compreendido como elemento estrutural de uma nação cuja forma de união é a cisão ${ }^{55}$. Daí, portanto, o caráter heurístico do esquema de Schwarz.

\section{Figuração da reconstrução}

Nos marcos da figuração do preservacionismo, analisada acima, outros tombamentos federais de bens individuais, além do Sambaqui do Pindaí e da Quinta das Laranjeiras, viriam a ocorrer nas décadas posteriores. Seriam inscritos no livro de Belas-Artes do Patrimônio a Fonte do Ribeirão, em 1950, e o Retábulo do Altar-Mór da Igreja Catedral de Nossa Senhora da Vitória (Igreja da Sé), em 1954. Em 1955 inicia-se o reconhecimento de conjuntos urbanos, sendo tombados nesse ano os "conjuntos arquitetônicos e paisagísticos" de quatro praças do centro de São Luís: Largo do Desterro, Praça Benedito Leite, Praça João Lisboa e Praça Gonçalves Dias. Na década de 60, foram reconhecidos imóveis na Praça Pedro II e o prédio da Academia Maranhense de Letras. Por fim, completando a trajetória de tombamentos federais, em 1974 é registrado como patrimônio histórico e artístico nacional o "conjunto arquitetônico e paisagístico da cidade de São Luís" - incluindo os bairros da Praia Grande, Desterro e Ribeirão -, cujo processo havia sido aberto em 1951. Para João Ricardo Costa Silva (2009, p. 8), nesse momento, “[s]urgia o Centro Histórico de São Luís, através da atuação do IPHAN".

É difícil precisar quando exatamente a categoria "centro histórico" passa a circular com mais intensidade em escala local. No entanto, é possível pontuar que, se em 1974 é reconhecido pelo IPHAN o "conjunto arquitetônico e urbanístico da cidade", em 1979, quando da gênese do Programa de Preservação e Revitalização do Centro Histórico de São

\footnotetext{
${ }^{55}$ O que não significa que seja a única nação cindida. Ainda assim, Drummond diria: "Nenhum Brasil existe. E acaso existirão os brasileiros?".
} 
Luís, que comentarei mais à frente, essa categoria já aparece explicitamente na razão de Estado. Quando tais eventos vieram a ocorrer, contudo, já estava sendo posto em processo o segundo momento decisivo que analisarei aqui.

Essa segunda figuração do processo de invenção do centro histórico de São Luís se desenvolve paulatinamente a partir principalmente da década de 1960, culminando, em 1988, com a política da imagem representada pela reconstrução do bairro central da Praia Grande (que, apesar de se concentrar apenas em uma região específica do centro antigo da cidade, envolve consequências simbólicas para todo o conjunto desse centro). É possível, então, tomar essa culminância como ponto de partida para percorrer os encadeamentos da trama que compõe esse fluxo de atribuição de sentido.

Em dezembro de 1988, Epitácio Cafeteira (1993, p. 126), então governador do Estado do Maranhão, decretava:

[...] considerando, finalmente, que, pela atual Constituição Federal, é dever do Poder Público, neste estando incluído obviamente a atuação do Governo do Estado do Maranhão, promover e proteger o patrimônio cultural brasileiro por meio de vigilância e de outras formas de acautelamento e preservação (art. 216, parágrafo $1^{\circ}$ )

\section{DECRETA:}

Art. $1^{\circ}$ : Fica proibido o tráfego de veículos automotores de carga e de passageiros, de qualquer tipo, nos arruamentos do Centro Histórico de São Luís nos trechos a seguir descritos; [...]

Art. $2^{\circ}$ : Ficam autorizadas as Secretarias de Cultura e de Transportes e Obras Públicas a promoverem as medidas complementares para a reconstrução e revitalização do acervo do Centro Histórico de São Luís de modo a dar a essa área, dentro do possível, a feição arquitetônica que ali predominava nos séculos passados,

dispondo o art. $3^{\circ}$ sobre a entrada imediata do decreto em vigor.

Nesses termos, ao longo de 1989, e com inauguração em dezembro desse ano, seriam executadas obras extensas no bairro da Praia Grande, restaurando sobrados e reconstruindo lampiões, calçadas e as ruas estreitas de paralelepípedos, destinadas a partir de então apenas ao trânsito de pedestres. Essas obras, realizadas no âmbito do que foi batizado como Projeto 
Reviver, envolveu, além da restauração de prédios históricos, obras grandes de infraestrutura, como a construção de redes subterrâneas para instalações elétricas, hidráulicas e cabos telefônicos. Também foram restauradas edificações históricas fora do bairro da Praia Grande - antes e depois da intervenção neste último -, a exemplo da antiga Fábrica Cânhamo, remanescente do breve surto de industrialização vivido por São Luís na passagem do século XIX para o XX, puxado pelo setor têxtil. Sobre essa obra em específico, um livro de divulgação do Projeto Reviver, publicado em 1993 pelo Senado Federal e assinado por Cafeteira (ex-governador e senador à época do lançamento do livro), afirma:

Sobreveio uma obra impressionante: a restauração integral da antiga Fábrica Cânhamo, com 5.500 metros quadrados de área construída, a maior obra de patrimônio realizada no País durante o ano de 1988. Ali foi instalado o primeiro grande centro de comercialização de artesanato do Maranhão, Ceprama. Essa obra sintetiza a filosofia do programa, ou seja, um espaço arquitetônico antes deteriorado e inacessível, hoje recuperado e aberto à comunidade, constituindo-se ao mesmo tempo atração turística e fonte de geração de emprego e renda. (CAFETEIRA, 1993, p. 30-31)

Nessa "filosofia", condensam-se uma série de sentidos consideravelmente distintos daqueles imputados pelo preservacionismo. Pois, no momento da reconstrução da Praia Grande, que traz consigo uma reconstrução simbólica de todo o centro histórico de São Luís, há uma nova tônica, que à época preservacionismo não era significativa: a do desenvolvimento econômico e do turismo, fins de certa forma reunidos no conceito de "revitalização". O surgimento dessa nova ênfase não exclui os sentidos da tradição anteriormente inventada, mas se constrói sobre ela; com efeito, ao falar do lugar do Projeto Reviver no interior de sua administração, Cafeteira diria que

uma dessas obras, das que mais me orgulho, é ponte e estrada ao mesmo tempo, que não é de concreto nem de asfalto. É uma "estrada" que resgata o passado, ligando-o ao nosso presente, como "ponte de fé" para o futuro de prosperidade que antevejo para o Maranhão. (CAFETEIRA, 1993, p. 17)

No entanto, apesar de efetivada em intervenção na paisagem urbana apenas no fim dos anos 80, essa "filosofia" faz parte de uma figuração que começa a se formar, no contexto maranhense, a partir principalmente da década de 60. Segundo José Marcelo do Espírito Santo, 
A sucessão de ações de tombamento federais surgidas como resposta às ações reurbanizadoras do poder público estadual foi acompanhada pela Prefeitura com a criação da Comissão do Patrimônio Artístico e Tradicional do Município e de um decreto-lei que impedia a demolição ou reforma de edifícios com mirantes e/ou azulejados. Naquele momento, a produção acadêmica e intelectual sobre o acervo ambiental urbano da cidade referenciava a preservação justificada pelos fatores históricos e de antiguidade de casarões isolados. Durante a década de 1960, porém, retornou o pensamento da necessidade de reformas urbanísticas na cidade antiga, em parte resultado do novo panorama político e da euforia econômica que se propunha para o Maranhão, com a quebra da oligarquia política de Vitorino Freire, de caráter fortemente conservador. Surgiram, nessa época, os principais exemplares de arquitetura moderna verticalizada no Centro Histórico de São Luís [...]. Os primeiros trabalhos sobre o acervo artístico e arquitetônico de São Luís, voltados a um aprofundamento científico [...], partiram da Unesco, por intermédio de seus representantes que estiveram na capital maranhense [...] [E]les conseguiram influenciar os trabalhos preservacionistas locais e, parcialmente, reverter o pensamento generalizado do governo e de camadas da intelectualidade sobre a substituição da cidade antiga pela imagem da modernidade adquirida no sul do país. (ESPÍRITO SANTO, 2009)

Dessa forma, foram enviados pela UNESCO, entre o fim dos anos 60 e o início dos 70, pelo menos dois arquitetos: o francês Michel Parent, em 1966, que entregou suas Propositions pour São Luís et Alcântara à organização em 1968, e o português Alfredo Viana de Lima, que produziu seus Rapport et propositions pour la conservation, récupération et expansion de São Luís/Maranhão em 1973, tendo este último documento chegado a orientar seções do Plano Diretor formulado pelo município de São Luís em 1974 (ESPÍRITO SANTO, 2009). Ambos os arquitetos, em suas respectivas missões, visitaram mais de uma cidade histórica brasileira para fins de consultoria: Salvador, Ouro Preto, Parati e Olinda estiveram em suas rotas.

José Sarney, governador do Maranhão de 1966 a 1970, cuja eleição inaugura o ciclo de modernização mencionado na passagem acima, aponta também a mediação do órgão nacional de preservação nesse trânsito: 
Quando eu era Governador do Maranhão, Rodrigo [Melo Franco de Andrade] conseguiu que a Unesco enviasse a São Luís o arquiteto Michel Parent, e, logo depois, em 1972, o grande arquiteto português Alfredo Viana de Lima, para fazer um diagnóstico da cidade e propor novas medidas de tombamento e proteção. (IPHAN, 2007, p. 16)

Assim, tem-se em um primeiro momento uma rede transnacional que une instâncias institucionais estaduais, federais e mundiais. No entanto, Luiz Phelipe Andrès, ocupante de uma posição-chave no interior da figuração da reconstrução por ter sido o engenheiro que, na direção do Departamento de Patrimônio Histórico da Secretaria de Cultura do Estado do Maranhão, coordenou o Projeto Reviver, relata, a respeito das indicações de Michel Parent, que "não se tem notícia do atendimento a tais recomendações importantes". De forma semelhante, ele acrescenta que "[r]epetindo-se, lamentavelmente, o destino do documento Parent, cai o documento Viana de Lima no esquecimento e abandono burocrático, não tendo sido seguidas as suas recomendações" (ANDRÈS, 1998, p. 56).

Contudo, qual era mais precisamente o conteúdo dessas propostas? Cecilia Ribeiro aponta, a respeito da missão de Michel Parent, que ele concedeu mais atenção ao que chamou de "cidades de arte". Essas cidades apresentariam em geral "um momento de pujança do passado e de pobreza e estagnação econômica no presente", o que lhes permitiria "comunicar um estado de inteireza e homogeneidade" (RIBEIRO, 2013, p. 55). Para elas, o arquiteto sugeria, além da preservação, a refuncionalização para fins de turismo cultural. A autora sintetiza as propostas de Parent para as chamadas "cidades de arte" (Salvador, São Luís, Ouro Preto, Parati e Olinda) em cinco tópicos: tombamento, restauração, elaboração de plano diretor, implementação de infraestrutura e estímulo ao turismo na forma de investimento em publicidade e na estrutura hoteleira.

Já Viana de Lima também viria a elaborar sugestões para a turistificação dos acervos das cidades históricas brasileiras, com ênfase em Ouro Preto. No relatório sobre a cidade mineira, o arquiteto "enfatizava, entre outras observações, a importância do patrimônio dessa cidade como o recurso capaz de deflagrar um novo ciclo econômico baseado no turismo cultural" (SANT'ANNA, 2016, p. 62). Nesse sentido, a passagem desses arquitetos estrangeiros é importante do ponto de vista da circulação de modelos normativos, sobretudo no que se refere à articulação entre patrimônio e turismo cultural, sem que ainda esses modelos se traduzam em intervenções efetivas na paisagem urbana de São Luís. 
Somando-se à influência dos mensageiros da UNESCO, um outro componente do fluxo de atribuição de sentido que culmina com o Projeto Reviver consiste no Programa de Reconstrução das Cidades Históricas, implementado pelo governo federal brasileiro a partir de 1973. Surgido na esteira da política econômica desenvolvimentista executada pelo Estado autoritário instalado com o golpe civil-militar de 1964, esse programa, que inicialmente se chamava Programa de Reconstrução das Cidades Históricas do Nordeste,

foi criado, assim, num contexto de renovação administrativa do Iphan e de mudança do paradigma preservacionista que ressaltava os valores estéticos e contemplativos do patrimônio, em prol da ênfase no seu valor econômico e na sua importância como insumo do turismo. Para tanto, como já haviam apontado diversos consultores da Unesco, era preciso buscar novas formas de gestão, juntar esforços e dividir a tarefa da preservação com outros entes governamentais. (SANT'ANNA, 2016, p. 63)

Dessa forma, participaram do programa não só o IPHAN, como também órgãos como a Empresa Brasileira de Turismo (EMBRATUR) e a Superintendência do Desenvolvimento do Nordeste (SUDENE). Segundo Márcia Sant’Anna, essas ideias

animaram a promoção dos célebres Encontros de Governadores, que ficaram conhecidos como Compromissos de Brasília (1970) e de Salvador (1971) eventos que começaram a mudar a face da gestão do patrimônio no Brasil e inauguraram o crescente envolvimento da esfera estadual na preservação do patrimônio cultural. (SANT’ANNA, 2016, p. 63)

É nesse contexto, marcado pela reorientação da política cultural federal, encadeada a uma rede transnacional, que nos anos 70 se começa a planejar uma intervenção no centro histórico de São Luís, orientada pela "filosofia" que a passagem do livro de divulgação citado acima enxerga na reforma e refuncionalização da Fábrica Cânhamo. A gênese dessa política da imagem, contudo, pode ser melhor acompanhada através da trajetória social de um indivíduo ocupante de uma posição relevante no interior da figuração da reconstrução: o engenheiro, mencionado acima, Luiz Phelipe Andrès. Andrès, mineiro com passagem pregressa pelo Rio de Janeiro, e que no fim da década de 70 trabalhava nas Centrais Elétricas do Maranhão (CEMAR), narra que

[a]costumado a visitar Ouro Preto e desenhar suas igrejas barrocas, fiquei surpreendido ao pisar pela primeira vez em São Luís em plenas águas de 
março de 1977. Impressionei-me com [...] a dimensão do conjunto arquitetônico do Centro Histórico [...]. [L]i notícia no jornal $O$ Estado do Maranhão que me chamou atenção pela coincidência do tema. Informava sobre uma Operação Monumentos Históricos, promovida pelo Projeto Rondon, então sob a direção de Carlos Nogueira Fontoura, que envolvia estudantes universitários em pesquisas sobre os principais monumentos de São Luís, Alcântara e Rosário. Ato contínuo, me ofereci como voluntário para ajudar na pesquisa. [...] [E]m março de 1979, não consegui mais voltar à rotina de engenheiro da empresa. $\mathrm{O}$ que fiz foi pleitear minha transferência para a Secretaria de Planejamento do Estado com o propósito de me irmanar aos trabalhos recém-iniciados de forma solitária pelo arquiteto John Ulrich Gisiger que no mesmo período aqui chegara e fora contratado [pela Secretaria de Planejamento do Estado] para desenvolver uma proposta de reabilitação do centro histórico de São Luís. [...] Foi esse plano de reabilitação, de autoria do John, que acabou suscitando a realização, no mês de outubro de 1979, de um grande encontro nacional, a I Convenção da Praia Grande, para discutir a preservação do valioso acervo, então muito degradado [...]. (ANDRÈS, 2012, p. 13-16)

Essa convenção, organizada pelo governo estadual em parceria com o IPHAN, então dirigido por Aluísio Magalhães (ator central da reorientação da política cultural brasileira em vários âmbitos), resultou na elaboração de um Programa de Preservação e Revitalização do Centro Histórico de São Luís (PPRCHSL). Com efeito, Andrès (2006) dedica sua dissertação de mestrado, de onde decorre o livro de onde foi extraída a passagem acima, e onde ele relata as fases sucessivas do programa, a este último gestor, dentre outros intelectuais.

No entanto, os dez primeiros anos do projeto se traduziram apenas em intervenções pontuais, a exemplo de uma reforma realizada na Feira da Praia Grande, que envolveu obras de infraestrutura e a reorganização de seu espaço interno, segundo Andrès (2006), de maneira negociada com os feirantes associados. A maior intervenção se daria de fato a partir de 1988, quando o Programa de Preservação e Revitalização do Centro Histórico, posteriormente chamado de Projeto Praia Grande, passa finalmente a se chamar Projeto Reviver. Aqui, mais do que uma descrição pormenorizada dos detalhes de cada ação dessas diversas fases da reconstrução material e simbólica do centro (já realizada em vários trabalhos e publicações, a exemplo de ANDRÈS, 1998, 1996, 2012; CAFETEIRA, 1993; CORRÊA, 2001; SILVA, 2010), interessaria mais captar o sentido geral dessa política da imagem. Esse sentido penso 
que pode ser compreendido se cotejado, uma vez mais, o livro de divulgação assinado por Cafeteira.

Pela leitura do texto do ex-governador, já no prefácio, é possível observar que, para ele, a "preservação da Praia Grande e as demais obras de restauração - que representam investimentos equivalentes a milhões de dólares - são o melhor exemplo de civilização" (CAFETEIRA, 1993, p. 18). Na sequência, passa a ser frequentemente mobilizada o que Silva (2010, p. 93) chama de uma "retórica da decadência": a indicação constante de estar aquela área da cidade, antes da intervenção, abandonada, degradada e/ou deteriorada. Assim, lemos que "[e]dificações que fizeram a glória da capital maranhense durante o apogeu dos séculos XVIII e XIX jaziam sob os escombros" (CAFETEIRA, 1993, p. 27). Nesse contexto, a noção de "glória" evidencia a duração de sentidos imputados por gerações anteriores: aquela de que os sobrados históricos seriam testemunho de um tempo imemorial de prosperidade, e símbolos da identidade local.

Ao seguir com a leitura, aprendemos que a "Praça do Comércio recebeu o plantio de árvores, recuperando-se a sua paisagem original conforme as fotografias do final do século XIX” (CAFETEIRA, 1993, p. 37). Nesse sentido, fica patente o fato de que a motivação por parte do governo foi, de fato, reconstruir a paisagem como imagem fiel do passado. Outras passagens, como a que descreve a obra de instalar em redes subterrâneas os cabos elétricos e telefônicos e as instalações hidráulicas, apontam que essa medida foi tomada "para retornar-se à paisagem do início do século" [XX] (CAFETEIRA, 1993, p. 61). Em outros momento, a mencionada "retórica da decadência" aparece associada a um discurso sobre segurança pública: segundo o político, antes do Reviver "[o]s terrenos baldios da Praia Grande haviam se transformado em depósitos de lixo, focos de ratos e moscas além de locais propícios à marginalidade, aumentando a insegurança da área" (CAFETEIRA, 1993, p. 76). Em mais uma passagem, ele chega a falar de um sobrado que havia se transformado em um "antro de marginais" (CAFETEIRA, 1993, p. 88). Dessa forma, refazer a imagem da "glória" pretérita passa também pela exclusão higienizadora de atores - e posições - sociais considerados indesejáveis, revelando também um elemento de tensão importante no interior desse tramado.

Sintetizando a análise dessa figuração, encontramos uma formação em que agentes estatais intervém para transformar - reconstruir - extensivamente a paisagem urbana, e não apenas garantir sua conservação, como na figuração anterior. Nessa reconstrução, atuam sentidos que à época circulavam em redes institucionais nacionais e transnacionais, como a 
refuncionalização orientada ao turismo cultural. Essa articulação entre preservação do patrimônio e turistificação seria confirmada, além disso, pela inscrição, em 1997, do centro histórico de São Luís na lista do Patrimônio Mundial da UNESCO, consagração que funciona desde então como mote da promoção da cidade no mercado turístico, por parte de agentes estatais e privados. No entanto, a forma particular que esses novos sentidos adquirem no contexto local é mediada pelas narrativas anteriormente construídas em torno da paisagem do centro antigo da cidade, como mostra o texto assinado por Cafeteira. Dessa forma, se configura a continuidade e a renovação da tradição inventada na primeira metade do século XX, reinventada por uma outra trama simbólica que enlaça arquitetos, engenheiros, políticos, empresários do turismo, e por outro lado comerciantes, moradores do centro histórico e trabalhadores da construção civil que, através de seus corpos, materializaram em paisagem urbana esse segundo grande fluxo de atribuição de sentido. 


\title{
Considerações finais
}

\section{Espaços públicos urbanos e processos de civilização}

\author{
[...] e sob as bibliotecas, os asilos, as igrejas triunfantes \\ e sob tu mesmo e sob teus pés já duros \\ e sob os gonzos da família e da classe, \\ fica sempre um pouco de tudo.
}

Carlos Drummond de Andrade, Resíduo

É preciso criar de novo, Luis Mauricio. Reinventar nagôs e latinos, e as mais severas inscrições, e quantos ensinamentos e os modelos mais finos.

Carlos Drummond de Andrade, A Luis Mauricio, infante

Segundo Maria de Lourdes Lauande Lacroix,

A decadência da lavoura do algodão, o endividamento em empréstimos para o fabrico do açúcar e a venda de escravos para São Paulo e Minas, não arrefeceram a euforia do antigo bem estar, da passada riqueza da elite maranhense e o esforço na assimilação de costumes e projetos de modernização da Paris burguesa e neoclássica. [...] O fascínio pela capital da França, que civiliza e transmite o gosto pela elegância, dominou a elite ludovicense. Os manuais de etiqueta ensinavam os hábitos à mesa, a arte de cumprimentar, cortejar, comer, beber, vestir, dançar, falar em público e, para o sexo feminino, como sentar ao piano, declamar, chegando a minúcias como a de usar o leque. (LACROIX, 2012, p. 229)

Já Rodrigo Melo Franco de Andrade, à época da instalação do SPHAN, afirmava:

Nos países civilizados - conclui o dr. Rodrigo Melo Franco de Andrade -, isso já está plenamente organizado. Recentemente se reuniu em Atenas uma conferência internacional para assentar, na órbita mundial, as mesmas e oportunas medidas que o nosso Serviço objetiva e sob o alto e inspirado sentido de que os patrimônios históricos e artísticos nacionais transcendem e são de interesse da comunidade universal. (ANDRADE, 1987, p. 25)

De acordo com Mariza Veloso, 
[a]lém das pesquisas, havia outra atividade extremamente importante na "Academia SPHAN". Trata-se dos cursos que eram administrados ou por técnicos da própria instituição - o que incluía os membros do Conselho Consultivo, pesquisadores, restauradores -, ou mesmo por algum especialista em temas que fossem do interesse da Academia. Como exemplo podemos citar: História das Artes, ministrado por Hanna Leyi, Arte Indígena, por Heloisa Alberto Torres; e Formação Material do Brasil, por Afonso Arinos de Melo Franco. Este último curso foi extremamente importante e marcou sobremaneira os membros da "Academia SPHAN", e consequentemente sua rede discursiva, pois nele, Afonso Arinos desenvolveu o conceito de civilização brasileira, o que de certa maneira definiu o eixo da narrativa da “Academia SPHAN". Nas entrevistas que realizamos, Lúcio Costa e Oscar Niemeyer fazem menção ao profundo significado e influência da noção de civilização, ligado à análise do século XVIII e do barroco, o que gerou uma perspectiva própria sobre a ideia de Brasil. Darcy Ribeiro, igualmente em entrevista que nos concedeu (Julho, 1990, Rio de Janeiro), comentou sobre este curso. Segundo ele o curso definiu de certa forma sua carreira intelectual, pois a partir daí dedicou anos de seus estudos e pesquisas à busca de elementos identificadores da civilização brasileira. (VELOSO, 1992, p. 299)

O ex-governador Epitácio Cafeteira (1993, p. 18), poucos anos depois de executado o Projeto Reviver, também escreveria:

A preservação da Praia Grande e as demais obras de restauração - que representam investimentos equivalentes a milhões de dólares - são o melhor exemplo de civilização.

Por fim, na opinião de Raquel Noronha (2015, p. 176; 210),

[u]m caráter civilizador é associado à ideia de patrimônio, fruto de seu direcionamento para o turismo, valorizando a necessidade da Feira ser "adequada" para ser vista pelas pessoas "de fora". [...] Os feirantes se apropriam de suas raízes na Feira, mantêm, valorizam e reinventam suas práticas cotidianas, suas tradições, porque sabem que isso é que faz a Feira ter valor para os gestores. O seu tambor, a sua boemia, as suas iguarias são patrimônio! Esse equilíbrio entre o processo civilizador de adequar a Feira ao turismo e a manutenção das características do uso da Feira pelos feirantes 
e pelas pessoas que frequentam a feira é o que faz desse espaço um lugar privilegiado para as disputas sobre o que é patrimônio.

O que essas passagens têm em comum? De pronto, salta aos olhos o destaque conferido ao conceito de civilização (o que não significa que sua semântica seja rigorosamente a mesma a cada aparição). Em O Processo Civilizador, Norbert Elias afirma que

[r]astreando a transformação de conceitos através dos quais diferentes sociedades procuraram se expressar, recuando do conceito de civilização para seu ancestral civilité, descobrimo-nos de repente na pista do próprio processo civilizador, da mudança concreta no comportamento que ocorreu no Ocidente. [...] Surge então a questão de saber como e por que a sociedade ocidental moveu-se realmente de um padrão para outro, como foi "civilizada". [...] Na verdade, nossos termos "civilizado" e "incivil" não constituem uma antítese do tipo existente entre o "bem" e o "mal", mas representam, sim, fases em um desenvolvimento que, além do mais, ainda continua. É também bem possível que nosso estágio de civilização, nosso comportamento, venham despertar em nossos descendentes um embaraço semelhante ao que, às vezes, sentimos ante o comportamento de nossos ancestrais. O comportamento social e a expressão de emoções passaram de uma forma e padrão que não eram um começo, que não podiam em sentido absoluto e indiferenciado ser designados de "incivil", para o nosso, que denotamos com a palavra "civilizado". (ELIAS, 1994, p. 72-73)

Em sua análise sociológica, assim, o autor procede a um exame cuidadoso da mudança, gradual e de longa duração, nos padrões de controle das emoções, padrões esses correlatos de estruturas sociais e psíquicas, engendradas por interdependências humanas e suas consequências não-programadas. Nesse sentido, Elias encontra, para a Europa ocidental, uma dinâmica intergeracional que ele começa a acompanhar a partir do momento em que a nobreza guerreira da Idade Média se reorganiza na forma curializada de sociedade de corte. A figuração de um padrão específico de autocontrole dos afetos surge, assim, no decorrer desse processo, como resultado de interdependências e pressões mútuas entre os aristocratas cortesãos. Os tabus que se disseminam, as formas prescritas de comportamento, que Elias, assim como Lacroix na passagem acima, encontra nos manuais de etiqueta, as modulações historicamente específicas de sentimentos como nojo, repulsa, vergonha, e por outro lado o padrão do que é ser civilizado, educado, correto, respeitoso, cortês, agradável, belo, enfim... 
são esses padrões arraigados nas psiques e nos corpos que ele destaca como significativos, e reúne sob o conceito de "processo de civilização".

Embora encontre sua validação empírica na observação dos costumes mais microscópicos, o modelo de Elias não deve enganar. Pois é de mudanças estruturais, ao mesmo tempo abrangentes e profundas, que o autor se ocupa quando descreve essas inflexões. Os valores mais sedimentados de uma sociedade, no caso, a de corte (muitos dos quais posteriormente transferidos à sociedade burguesa), também se observam nos detalhes, na medida em que, se postos em perspectiva histórica e comparativa, eles revelam suas funções integradoras. Nesse sentido, e em outros, a contribuição de Elias consiste em valiosa inspiração metodológica. Ainda assim, do ponto de vista do material histórico que explica, ela continua sendo um modelo de um processo civilizador específico, a saber, aquele da Europa ocidental. O que acontece quando deslocamos o problema para o lado de baixo do Equador?

Salete Nery (2016) oferece uma pista, na medida em que opera um procedimento de compatibilização teórica que aqui, ao menos em alguns pontos, interessa repetir. Na pesquisa da autora encontramos a proposta de uma "sociologia das interpenetrações", calibrada a partir das contribuições teóricas de Elias e Roger Bastide, extraindo deste último especialmente o conceito de interpenetração civilizatória. Nessa perspectiva, Nery opta por manter o filtro de interpretação tradicional de tomar os processos sociais brasileiros como tributários das implicações mútuas entre indígenas, negros africanos e brancos europeus; no entanto, seguindo a sociologia das interpenetrações feita por Bastide através da análise das religiosidades africanas no Brasil, ela chama atenção para os arranjos específicos dessas interdependências em diferentes espaços e tempos históricos. As figurações formadas por tais interdependências devem ser "pensadas e interpretadas espacialmente num sentido tríplice: enquanto (1) distâncias geográficas e (2) sociais que assumem (3) caráter específico a depender do lugar do país" (NERY, 2016, p. 697). Para a autora,

[u]ma das evidentes conclusões é que fica bastante difícil pensar as relações como simples simbiose de costumes estabelecida pelo simples contato entre povos. Interpenetrações se dão nas e pelas interdependências e, portanto, seu grau depende do teor de força de cada grupo dentro de tais relações, que podem ter diferentes resultados. De qualquer modo, o jogo da relação entre tradições leva a que o jogador aja em função da ação do(s) outro(s) e da ideia que tem do jogo, como nos lembra Norbert Elias (1999), o que nos leva a considerar um simultâneo trabalho hermenêutico de interpretação desses 
outros e do jogo em função do horizonte de significados, da tradição de cada jogador particular. [...] Por outro lado, a noção de interdependência conjugada à de interpenetração remete-nos à percepção de que não apenas se trata de processos em curso, mas que as dependências e, portanto, as interpenetrações se dão em ambos os lados, apesar das mencionadas diferenças em grau e resultados - além de sermos obrigados a pensar do ponto de vista das resistências. (NERY, 2016, p. 699-700)

Dessa forma, é pelos fios dessa trama complexa de pressões e resistências que se tecem, no Brasil, os longos processos de padronização das emoções identificados por Elias.

É nesse sentido que seria possível sugerir uma comparação entre os materiais encontrados na incursão etnográfica e aqueles abordados na análise figuracional. Pensando a invenção do centro histórico de São Luís como atravessada por processos civilizadores distintos, quais significados emergiriam? O que significaria cada uma das figuras analisadas, e mais ainda suas tensões internas? Quais pressões cada política da imagem que mencionei acaba por exercer sobre imaginários e emoções? É claro que as respostas a essas questões não caberiam no escopo destas considerações finais. Antes, a intenção é levantar matéria para uma reflexão, um último olhar contemplativo sobre o centro da cidade, pelo prisma alargado dos processos de civilização e da longa duração dos afetos.

Nesta monografia, procurei responder à questão: como se inventa um centro histórico? A análise só pode tentar caminhar e ir tropeçando nos sentidos de que ele é feito. Ela percorre aos poucos os nexos, as múltiplas determinações do concreto, abstraindo umas e ignorando outras, sem jamais chegar a um fim definitivo; no máximo, chegando a uma síntese provisória. Se fosse possível uma resposta unívoca, ela teria que incluir a polissemia e a contradição, pois é assim que se constrói uma cidade; ainda mais quando se acopla a ela o adjetivo "histórica". Qual história, afinal?

$\mathrm{Na}$ introdução deste trabalho, deixei por explicar a proposição de que o centro histórico de São Luís seria um espaço diferente, e mesmo uma contraparte, da lógica de segregação socioespacial dos condomínios privados, neste país de casas-grandes e senzalas, sobrados e mucambos, condomínios e favelas ${ }^{56}$. Essa explicação penso que se encontra na definição dada por Rogério Proença Leite do que seria um espaço público:

\footnotetext{
${ }^{56}$ A tese de Pedro Herculano de Souza (2016) mostrou, por exemplo, que o grau de concentração de renda entre o $1 \%$ mais rico da população brasileira se manteve relativamente estável entre 1926 e 2013.
} 
Embora o espaço público, portanto, se constitua como espaço urbano, é possível entendê-lo como uma categoria sociológica que ultrapassa a rua, constituída pelas práticas que atribuem sentidos e estruturam lugares. [...] Não são os ares de uma cidade enobrecida que libertam, mas as formas cotidianas de apropriação política dos lugares, que publicizam e politizam as diferenças, atribuindo sentidos e qualificando os espaços da cidade como espaços públicos. [...] Essas disputas não ocorrem em qualquer rua e nem de modo aleatório. A "rua que interessa" (Magnani, 1998) é aquela cuja ritualização cotidiana dos usos e da construção dos lugares lhes imprime significados. (LEITE, 2001, p. 222; 361; 367)

A meu ver, o centro histórico de São Luís é um espaço desse tipo, precisamente por essa razão: permite que padrões civilizatórios diferentes se encontrem, se vejam, se estranhem, se friccionem e se interpenetrem. É um pouco a mistura - que, evidentemente, não cancela desigualdades históricas - de tradições e valores, hábitos e práticas, imagens e imaginários, éticas e estéticas diferentes que compartilham um mesmo palco. É também, de certa forma, a possibilidade de uma experiência social mais aberta à heterogeneidade, às trocas simbólicas e às disputas de sentido, aquecendo assim moléculas que a lógica de condomínio, por delas querer distância, preferiria congelar. 


\section{Referências bibliográficas}

ALBERNAZ, Lady Selma Ferreira. O "Urrou” do Boi em Atenas: instituições, experiências culturais e identidade no Maranhão. Tese (Doutorado em Ciências Sociais) - Instituto de Filosofia e Ciências Humanas, Universidade Estadual de Campinas, Campinas, 2004.

ALBUQUERQUE JÚNIOR, Durval Muniz de. A invenção do Nordeste e outras artes. São Paulo: Cortez, 2011.

ALMEIDA, Alfredo Wagner Berno de. A Ideologia da Decadência: leitura antropológica a uma história da agricultura no Maranhão. Rio de Janeiro: Editora Casa 8; Fundação Universidade do Amazonas, 2008.

ANDRADE, Rodrigo Melo Franco de. Rodrigo e o SPHAN. Rio de Janeiro: Ministério da Cultura; Fundação Nacional Pró-Memória, 1987.

ANDRÈS, Luiz Phelipe de Carvalho Castro (Org.). Centro Histórico de São Luís Maranhão: patrimônio mundial. São Paulo: Audichomo Editora, 1998.

ANDRÈS, Luiz Phelipe de Carvalho Castro. Reabilitação do Centro Histórico de São Luís: análise crítica do Programa de Preservação e Revitalização do Centro Histórico de São Luís/PPRCHSL, sob o enfoque da conservação urbana integrada. Dissertação (Mestrado em Desenvolvimento Urbano) - Pós-Graduação em Desenvolvimento Urbano, Universidade Federal de Pernambuco, Recife, 2006.

ANDRÈS, Luiz Phelipe de Carvalho Castro. São Luís - Reabilitação do Centro Histórico Patrimônio da Humanidade. São Luís: Foto Edgar Rocha, 2012.

ARANTES, Antonio Augusto. "O Patrimônio Cultural e seus usos: a dimensão urbana." In: Habitus. Goiânia, v. 4, n.1, p. 425-435, jan./jun. 2006.

ARGAN, Giulio Carlo. História da arte como história da cidade. São Paulo: Martins Fontes, 2005.

ASSIS, Joaquim Maria Machado de. Obra Completa. Vol. 2. Rio de Janeiro: Nova Aguilar, 1994.

BENJAMIN, Walter. Origem do Drama Barroco Alemão. São Paulo: Brasiliense, 1984.

BENJAMIN, Walter. Obras Escolhidas, volume I: Magia e técnica, arte e política; $5^{\text {a }}$ edição. São Paulo: Brasiliense, 1993.

BERNARDO, André. Índios gays: amor e ódio na colônia. Reportagem. S/d. Disponível em: http://aventurasnahistoria.uol.com.br/noticias/terra-brasilis/indios-gays-amor-e-odio-nacolonia.phtml\#.WPw YuNLyvIU . Acesso em 23/04/2017. 
BORRALHO, José Henrique de Paula. A Athenas Equinocial: a fundação de um Maranhão no Império Brasileiro. Tese (Doutorado em História) - Programa de Pós-Graduação em História, Universidade Federal Fluminense, Niterói, 2009.

BOURDIEU, Pierre. Meditações Pascalianas. Rio de Janeiro: Bertrand Brasil, 2001.

BOURDIEU, Pierre. A Distinção: crítica social do julgamento. São Paulo: Edusp; Porto Alegre: Zouk, 2007.

CAFETEIRA, Epitácio. Reviver. Brasília: Senado Federal, Centro Gráfico, 1993.

CALDEIRA, Teresa Pires do Rio. Cidade de Muros: crime, segregação e cidadania em São Paulo. São Paulo: Ed. 34; Edusp, 2000.

CANCLINI, Néstor García. Culturas Híbridas: estratégias para entrar e sair da modernidade. São Paulo: Editora da Universidade de São Paulo, 1998.

CANTARELLI, Rodrigo. Inspetoria de Monumentos de Pernambuco (1928-1933). Pesquisa Escolar Online, Fundação Joaquim Nabuco, Recife, 2014. Disponível em: <http://basilio.fundaj.gov.br/pesquisaescolar/ . Acesso em 13/11/2017.

CHAVES, César Roberto Castro; SILVA, Brenda Veneranda Fernandes. "Sociabilidades e Patrimônio Cultural: um olhar sobre o sentido da preservação a partir da memória socialmente construída em São Luís/MA". In: Revista do CEDS - Periódico do Centro de Estudos em Desenvolvimento Sustentável da UNDB. São Luís, N. 3, V. 1, setembro/dezembro, 2015.

CLIFFORD, James. A Experiência Etnográfica: antropologia e literatura no século XX. Rio de Janeiro: Editora UFRJ, 2002.

CORRÊA, Alexandre Fernandes. Vilas, Parques, Bairros e Terreiros: novos patrimônios na cena das políticas culturais em São Paulo e São Luís. Tese (Doutorado em Ciências Sociais) Programa de Pós-Graduação em Ciências Sociais, Pontifícia Universidade Católica, São Paulo, 2001.

CORRÊA, Alexandre Fernandes. Guerra das Imagens e Memórias Enxertadas: monumentos, museus e memórias históricas em conflito. Comunicação. VIII Seminário Internacional Políticas Culturais, Fundação Casa de Rui Barbosa, Rio de Janeiro, 23 a 26 de maio de 2017.

CORRÊA, Rossini. Formação Social do Maranhão: o presente de uma arqueologia. São Luís: SIOGE, 1993.

COSTA, Wagner Cabral da. "Ruínas Verdes: tradição e decadência nos imaginários sociais." In: Cadernos de Pesquisa. São Luís, V. 12, N. 1/2, p. 79-105, jan./dez. 2001.

DAMATTA, Roberto. A casa e a rua: espaço, cidadania, mulher e morte no Brasil. Rio de Janeiro: Rocco, 1997. 
D'EVREUX, Yves. Viagem ao norte do Brasil feita nos annos de 1613 a 1614. Maranhão: Typ. do Frias, 1874. Disponível em: https://archive.org/details/viagemaonortedo00yvesgoog . Acesso em 23/04/2017.

DIDI-HUBERMAN, Georges. A imagem sobrevivente: história da arte e tempo dos fantasmas segundo Aby Warburg. Rio de Janeiro: Contraponto, 2013.

DUNKER, Christian. Mal-Estar, Sofrimento e Sintoma: uma psicopatologia do Brasil entre muros. São Paulo: Boitempo, 2015.

ELIAS, Norbert. O Processo Civilizador: uma História dos Costumes (Vol. 1). Rio de Janeiro: Jorge Zahar Editor, 1994.

ELIAS, Norbert. O Processo Civilizador: Formação do Estado e Civilização (Vol. 2). Rio de Janeiro: Jorge Zahar Editor, 1993.

ELIAS, Norbert. Teoria Simbólica. Oeiras: Celta Editora, 1994.

ELIAS, Norbert. Envolvimento e Alienação. Rio de Janeiro: Bertrand Brasil, 1998.

ELIAS, Norbert. A Sociedade de Corte: investigação sobre a sociologia da realeza e da aristocracia de corte. Rio de Janeiro: Jorge Zahar Editor, 2001.

ESPÍRITO SANTO, José Marcelo. "Plano municipal de gestão: a revitalização do centro histórico de São Luís". In: VARGAS, Heliana Comin; CASTILHO, Ana Luisa Howard (Orgs.). Intervenções em Centros Urbanos: objetivos, estratégias e resultados. Barueri: Manole, 2009.

FARIAS, Edson. "Tensões em um Projeto Civilizador Baiano". In: Projeto UNESCO no Brasil: textos críticos. Organização: Cláudio Luiz Pereira e Livio Sansone. Salvador: EDUFBA, 2007.

FERNANDES, Estevão Rafael. "Homossexualidade indígena no Brasil: desafios de uma pesquisa." In: Novos Debates: fórum de debates em antropologia. Brasília, V. 1, N. 2, 2014.

FLORES, Richard R.. Remembering the Alamo: memory, modernity and the master symbol. Austin: University of Texas Press, 2002.

FONSECA, Maria Cecília Londres. O Patrimônio em Processo: trajetória da política federal de preservação no Brasil. Rio de Janeiro: UFRJ/MinC-IPHAN, 1997.

FREYRE, Gilberto. Sobrados e Mucambos: decadência do patriarcado rural e desenvolvimento urbano. In: Intérpretes do Brasil (Vol. 2). Rio de Janeiro: Nova Aguilar, 2002.

FURTADO, Celso. Formação Econômica do Brasil. São Paulo: Companhia das Letras, 2009.

GILROY, Paul. O Atlântico Negro: modernidade e dupla consciência. São Paulo: Ed. 34; Rio de Janeiro: Universidade Candido Mendes, Centro de Estudos Afro-Asiáticos, 2001. 
GRAMSCI, Antonio. Cadernos do Cárcere. Vol. 3. Edição e tradução: Carlos Nelson Coutinho. Rio de Janeiro: Civilização Brasileira, 2007.

GRUZINSKI, Serge. A Guerra das Imagens: de Cristóvão Colombo a Blade Runner (1492 2019). São Paulo: Companhia das Letras, 2006.

HOBSBAWM, Eric; RANGER, Terence. The Invention of Tradition. Cambridge: Cambridge University Press, 1983.

HOLANDA, Sérgio Buarque de. Raízes do Brasil. São Paulo: Companhia das Letras, 1995.

IPHAN. Cidades Históricas; Inventário e Pesquisa: São Luís. Brasília: Edições do Senado Federal; Rio de Janeiro: IPHAN, 2007.

IPHAN. Proteção e Revitalização do Patrimônio Cultural no Brasil: uma trajetória. Publicações da Secretaria do Patrimônio Histórico e Artístico Nacional. N. 31. Brasília: MEC; SPHAN; Fundação Nacional Pró-Memória, 1980. Disponível em http://portal.iphan.gov.br/uploads/ckfinder/arquivos/Protecao_revitalizacao_patrimonio_cultu ral(1).pdf . Acesso em 13/11/2017.

LACROIX, Maria de Lourdes Lauande. A fundação francesa de São Luís e seus mitos. São Luís: EdUFMA, 2000.

LACROIX, Maria de Lourdes Lauande. São Luís do Maranhão: corpo e alma. São Luís: 2012.

LE CORBUSIER. A Carta de Atenas. São Paulo: HUCITEC; EDUSP, 1993.

LEITE, Rogerio Proença de Sousa. Espaço Público e Política dos Lugares: usos do patrimônio cultural na reinvenção contemporânea do Recife Antigo. Tese (Doutorado em Antropologia) - Instituto de Filosofia e Ciências Humanas, Universidade Estadual de Campinas, Campinas, 2001.

LOPES, José Antonio Viana. Capital Moderna e Cidade Colonial: o pensamento preservacionista na história do urbanismo ludovicense. Dissertação (Mestrado em Desenvolvimento Urbano) - Programa de Pós-Graduação em Desenvolvimento Urbano, Universidade Federal de Pernambuco, Recife, 2004.

MARICATO, Ermínia [et al.]. Cidades Rebeldes: Passe Livre e as manifestações que tomaram as ruas do Brasil. São Paulo: Boitempo; Carta Maior, 2013.

MARX, Karl. Grundrisse. São Paulo: Boitempo, 2011.

MAUSS, Marcel. Sociologia e Antropologia. São Paulo: Cosac Naify, 2003.

MEIRELES, Mário M. História do Maranhão. São Luís: Academia Maranhense de Letras, 2015.

MICELI, Sergio. Intelectuais à brasileira. São Paulo: Companhia das Letras, 2001. 
MONDZAIN, Marie-José. Imagem, Ícone, Economia: as fontes bizantinas do imaginário contemporâneo. Rio de Janeiro: Contraponto; Museu de Arte do Rio, 2013.

MOURA, Clóvis. Rebeliões da Senzala. Porto Alegre: Mercado Aberto, 1988.

MOURA, Clóvis. Dicionário da Escravidão Negra no Brasil. São Paulo: Editora da Universidade de São Paulo, 2004.

NERY, Salete. "Interdependências e interpenetrações civilizatórias: os aromas e sua magia." In: Sociedade e Estado. Brasília, V. 31, N. 3, Setembro/Dezembro, 2016.

NORA, Pierre. "Entre Memória e História: a problemática dos lugares". In: Projeto História, São Paulo, V. 10, dez. 1993.

NORONHA, Raquel. No Coração da Praia Grande: representações sobre a noção de patrimônio na Feira da Praia Grande - São Luís - Maranhão. São Luís: EdUFMA, 2015.

ORTIZ, Renato. A Moderna Tradição Brasileira: cultura brasileira e indústria cultural. São Paulo: Brasiliense, 2001.

ORTIZ, Renato. Universalismo e Diversidade: contradições da modernidade-mundo. São Paulo: Boitempo, 2015.

PINHO, Osmundo S. de Araújo. Descentrando o Pelô: narrativas, territórios e desigualdades raciais no centro histórico de Salvador. Dissertação (Mestrado em Antropologia Social) Instituto de Filosofia e Ciências Humanas, Universidade Estadual de Campinas, Campinas, 1996.

QUIJANO, Aníbal. “Colonialidad y Modernidad/Racionalidad”. In: Perú Indígena. V. 13, N. 29, 1992.

REIS, Carlos Madson. Gestão de Centros Históricos no Brasil: as cidades patrimônio mundial, o caso de Brasília e São Luís. Tese (Doutorado em Arquitetura e Urbanismo) Faculdade de Arquitetura e Urbanismo, Universidade de Brasília, Brasília, 2011.

RIBEIRO, Cecilia. "Viana de Lima em Missão da UNESCO no Brasil." In: URBANA. Campinas, CIEC/UNICAMP, V.5, N. 6, mar. 2013.

RIBEIRO JÚNIOR, José Reinaldo Barros. Formação do Espaço Urbano de São Luís: 16121991. São Luís: Edições FUNC, 1999.

SANT'ANNA, Márcia. “A herança do PCH: balanço crítico e desdobramentos 40 anos depois." In: Anais do Museu Paulista. São Paulo. N. Sér. v.24. n.1. p. 59-74. jan.- abr. 2016.

SANTOS, Antônio Bispo dos. Colonização, Quilombos: modos e significados. Brasília: INCTI/UnB, 2015.

SANTOS, Milton. A Natureza do Espaço: Técnica e Tempo, Razão e Emoção. São Paulo: Editora da Universidade de São Paulo, 2006. 
SCHWARZ, Roberto. "As ideias fora do lugar". In: Ao vencedor as batatas: forma literária e processo social nos inícios do romance brasileiro. São Paulo: Duas Cidades, 2000.

SCHWARZ, Roberto. Que horas são? São Paulo: Companhia das Letras, 1987.

SCHWARZ, Roberto. O Pai de Família e outros estudos. São Paulo: Companhia das Letras, 2008 .

SILVA, Georgia Patrícia. De Volta à Praia Grande: o "velho" centro com o "novo" discurso. Tese (Doutorado em Políticas Públicas) - Programa de Pós-Graduação em Políticas Públicas, Universidade Federal do Maranhão, São Luís, 2010.

SILVA, João Ricardo Costa. O Processo de Patrimonialização do Centro Antigo de São Luís: práticas patrimoniais desenvolvidas pelo poder público. Comunicação. ANPUH - XXV Simpósio Nacional de História - Fortaleza, 2009.

SOUZA, Jessé. A Modernização Seletiva: uma reinterpretação do dilema brasileiro. Brasília: Editora da Universidade de Brasília, 2000.

SOUZA, Pedro Herculano Guimarães Ferreira de. A desigualdade vista do topo: a concentração de renda entre os ricos no Brasil, 1926-2013. Tese (Doutorado em Sociologia) Programa de Pós-Graduação em Sociologia, Universidade de Brasília, Brasília, 2016.

TAVARES, Luiz Fabiano de Freitas. A Ilha e o Tempo: séculos e vidas de São Luís do Maranhão (1612-2012). São Luís: Instituto Geia, 2012.

VELOSO, Mariza. O Tecido do Tempo: a ideia de patrimônio cultural no Brasil (1920-1970). Tese (Doutorado em Antropologia Social) - Programa de Pós-Graduação em Antropologia Social, Universidade de Brasília, Brasília, 1992.

VIVEIROS, Jerônimo de. História do Comércio do Maranhão. São Luis: Associação Comercial do Maranhão; EDUFMA, 2014.

WEBER, Max. A Ética Protestante e o "Espírito" do Capitalismo. São Paulo: Companhia das Letras, 2004.

WEBER, Max. Economia e Sociedade: fundamentos da sociologia compreensiva (Vol. 1). Brasília: Editora Universidade de Brasília, 2012.

WISNIK, José Miguel. “O que se pode saber de um homem?”. In: piauí, n. 109, outubro, 2015.

ZIN, Rafael Balseiro. Maria Firmina dos Reis: a trajetória intelectual de uma escritora afrodescendente no Brasil oitocentista. Dissertação (Mestrado em Ciências Sociais) Faculdade de Ciências Sociais, Pontifícia Universidade Católica, São Paulo, 2016. 